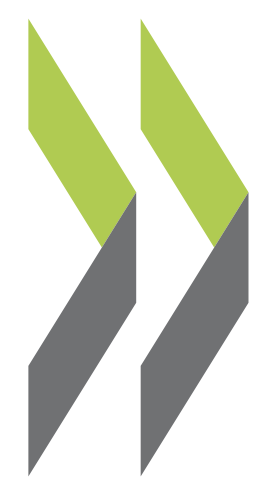

OECD Social, Employment and Migration Working Papers No. 159

\title{
Trends in Top Incomes and their Taxation in OECD Countries
}

\author{
Michael Förster, \\ Ana Llena-Nozal, \\ Vahé Nafilyan
}


Organisation de Coopération et de Développement Économiques

Organisation for Economic Co-operation and Development

DIRECTORATE FOR EMPLOYMENT, LABOUR AND SOCIAL AFFAIRS

English - Or. English

EMPLOYMENT, LABOUR AND SOCIAL AFFAIRS COMMITTEE

OECD SOCIAL, EMPLOYMENT AND MIGRATION WORKING PAPERS No. 159

Trends in Top Incomes and their Taxation in OECD Countries

Michael Förster, Ana Llena-Nozal, Vahé Nafilyan*

JEL Classification:

D31, D63, H2O

*Michael Förster and Ana Llena-Nozal are from the Social Policy Division, OECD Directorate for Employment, Labour and Social Affairs. Vahé Nafilyan was a consultant with the OECD Social Policy Division at the time of writing and is currently with the Institute for Employment Studies, Brighton, UK.

Authorised for publication by Stefano Scarpetta, Director, Directorate for Employment, Labour and Social Affairs.

All Social, Employment and Migration Working Papers are now available through the OECD website at www.oecd.org/els/workingpapers.

Complete document available on OLIS in its original format

This document and any map included herein are without prejudice to the status of or sovereignty over any territory, to the delimitation of international frontiers and boundaries and to the name of any territory, city or area. 


\title{
OECD SOCIAL, EMPLOYMENT AND MIGRATION WORKING PAPERS
}

\author{
www.oecd.org/els/workingpapers
}

OECD Working Papers should not be reported as representing the official views of the OECD or of its member countries. The opinions expressed and arguments employed are those of the author(s).

Working Papers describe preliminary results or research in progress by the author(s) and are published to stimulate discussion on a broad range of issues on which the OECD works. Comments on Working Papers are welcomed, and may be sent to the Directorate for Employment, Labour and Social Affairs OECD, 2 rue André-Pascal, 75775 Paris Cedex 16, France.

This series is designed to make available to a wider readership selected labour market, social policy and migration studies prepared for use within the OECD. Authorship is usually collective, but principal writers are named. The papers are generally available only in their original language - English or French with a summary in the other.

\author{
Applications for permission to reproduce or translate \\ all or part of this material should be made to:
Head of Publications Service
OECD
2, rue André-Pascal
75775 Paris, CEDEX 16
France \\ Copyright OECD 2014
}




\section{ACKNOWLEGMENTS}

This report has been produced with the assistance of the European Union. It is part of the joint OECD/EU project "Jobs, Wages and Inequality" (2012 - 2014). The study has been presented and discussed at October 2013 meeting of the Employment, Labour and Social Affairs Committee as well as at the Joint OECD/EU Technical Workshop in November 2013 and benefited from the comments received by delegates and participants.

The authors, Michael Förster and Ana Llena-Nozal (Social Policy Division of the Directorate for Employment, Labour and Social Affairs at OECD) as well as Vahé Nafilyan (Institute for Employment Studies, Brighton, UK) would like to thank the experts of the OECD Centre for Tax Policy and Administration for helpful comments and suggestions received on earlier versions of the paper, in particular by Bert Brys and Stephen Matthews. We also thank Facundo Alvaredo for advice on the use of data from the World Top Incomes Database. Any remaining errors are the authors' alone. 


\begin{abstract}
The shares of top income recipients in total pre-tax income have increased in OECD countries in the past three decades, particularly in most of the English-speaking countries but also in some Nordic (from low levels) and Southern European countries. Today, the richest one percent receives between $7 \%$ of all pre-tax income in Denmark and the Netherlands up to almost $20 \%$ in the United States. This increase is the result of the top $1 \%$ capturing a disproportionate share of overall income growth over the past thirty years: around $20-25 \%$ in Australia and the United Kingdom, up to 37\% in Canada and even $47 \%$ in the United States. At the same time, tax reforms in almost all OECD countries reduced top personal income tax rates as well as rates of other taxes affecting the highest income earners. Indeed, while top tax rates were equal to or above $70 \%$ in half of the countries in the mid-1970s, this rate has been halved in many countries by 2013.

These trends have come to a halt during the first two years of the Great Recession, with falling top incomes especially during 2009. Also, since 2008, 21 OECD countries have increased their top PIT rate while only three countries reduced it. That halt did, however, not undo the previous surge in top incomes and it also appeared to be temporary in many countries, as top incomes largely recovered and grew faster than the majority of incomes since 2010, e.g. in Australia, Denmark, Norway, Sweden and the United States. To respond to these trends, governments have several options at hand to increase effective taxation paid by top income recipients without necessarily raising their marginal rates, to improve tax compliance and to reduce tax avoidance.
\end{abstract}


DELSA/ELSA/WD/SEM(2014)5

\section{RÉSUMÉ}

Au cours des trois dernières décennies, la part du revenu avant impôts revenant aux titulaires de hauts revenus a augmenté au sein des pays de l'OCDE, en particulier dans la plupart des pays anglophones mais aussi dans certains pays nordiques (démarrant toutefois d'un niveau relativement bas) et certains pays du sud de l'Europe. Aujourd'hui, les un pourcent les plus riches perçoivent entre 7\% du revenu individuel total avant impôts au Danemark et aux Pays-Bas et presque 20\% aux États-Unis. Cette forte progression est le résultat d'un partage inéquitable des fruits de la croissance des revenus aux cours des trente dernières années. En effet, entre $20 \%$ et $25 \%$ des bénéfices de la croissance est captée par les un pourcent les plus riches en Australie et au Royaume-Uni, et jusqu'à 37\% au Canada, voire 47\% aux États-Unis. Dans le même temps, les réformes fiscales de la plupart des pays de l'OCDE ont été dans le sens d'une réduction des taux d'imposition et d'autres taxes affectant les plus hauts revenus. Ainsi, alors que les taux d'imposition des plus hauts revenus étaient aux alentours de 70\% dans la moitié des pays de 1'OCDE dans les années 70, ils sont, en 2013, réduits de moitié dans de nombreux pays.

Cette tendance a marqué une pause au cours des deux premières années de la "Grande Récession », par une baisse des plus haut revenus, en particulier en 2009. Par ailleurs, depuis 2008, 21 pays de l'OCDE ont augmenté leur taux d'imposition des plus hauts revenus alors que seulement trois pays les ont réduits. Cette pause n'a cependant pas annulé la hausse précédente de la part des plus hauts revenus et est apparue comme temporaire dans de nombreux pays. En effet, depuis 2010, les plus hauts revenus ont largement récupéré et ont crû plus rapidement que la majorité des autres revenus, notamment, en Australie, au Danemark, en Norvège, en Suède et aux États- Unis. Afin de répondre à cette tendance, les gouvernements disposent de plusieurs options pour augmenter l'impôt effectif payé par les bénéficiaires des plus hauts revenus sans nécessairement augmenter leur taux marginal, et pour améliorer la conformité fiscale et réduire l'évasion. 


\section{TABLE OF CONTENTS}

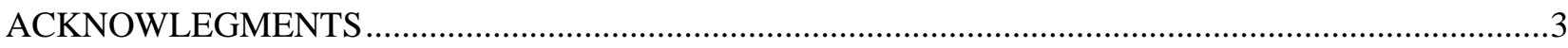

ABSTRACT …

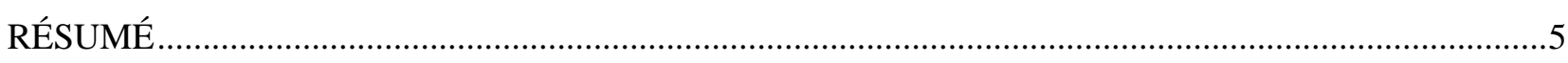

TRENDS IN TOP INCOMES AND THEIR TAXATION IN OECD COUNTRIES ................................9

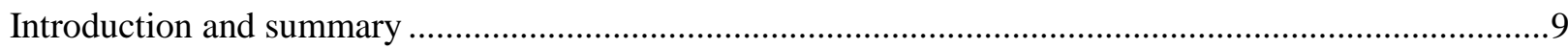

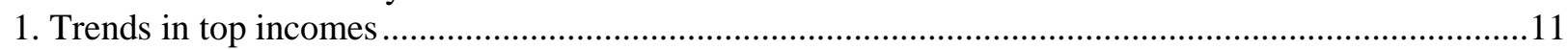

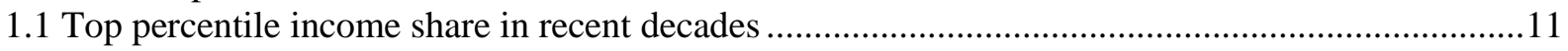

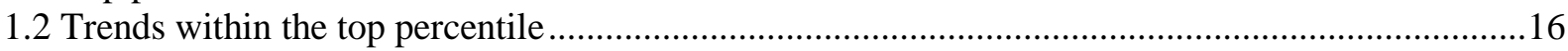

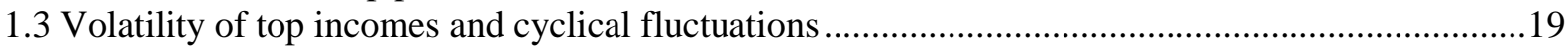

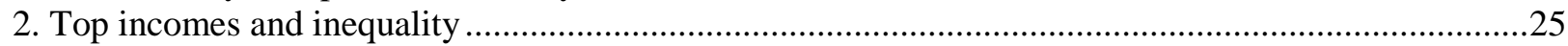

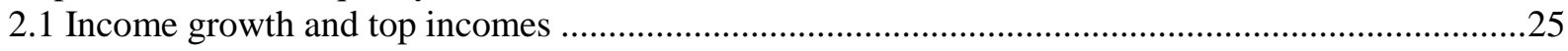

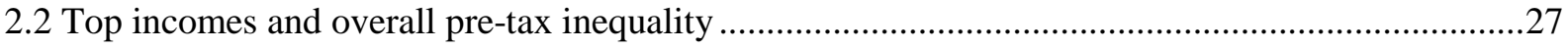

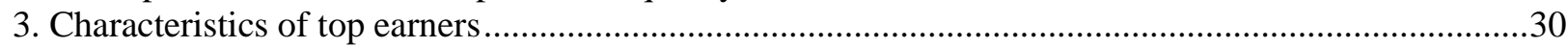

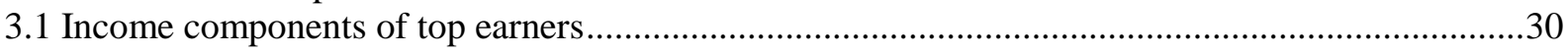

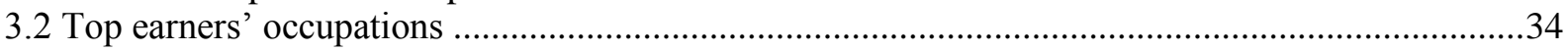

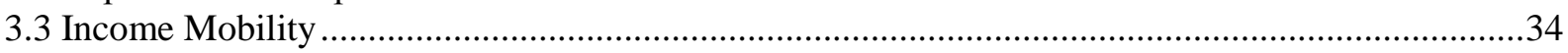

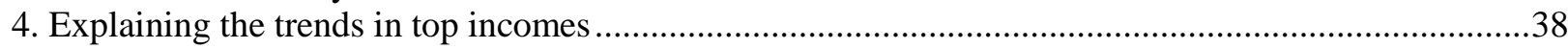

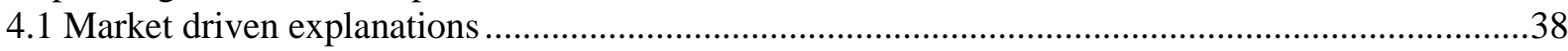

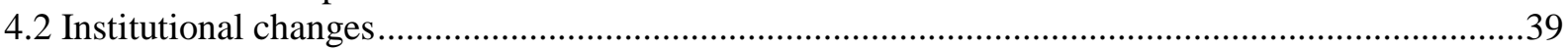

5. Characteristics and trends of taxes affecting top incomes .................................................................43

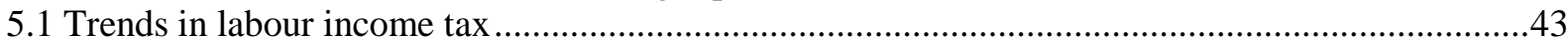

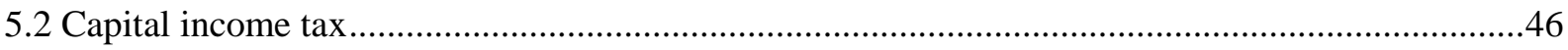

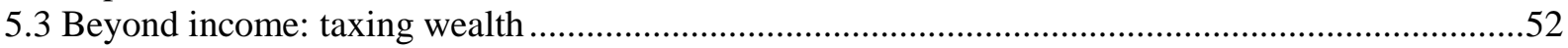

6. Changes in tax policy and top incomes' behaviour ..........................................................................59

6.1 How responsive are top incomes to changes in marginal tax rates on income? ..............................59

6.2 Is there an optimal tax rate for top incomes: efficiency, equity and revenue trade-offs ..................62

6.3 Policy trade-offs between different forms of taxation...................................................................64

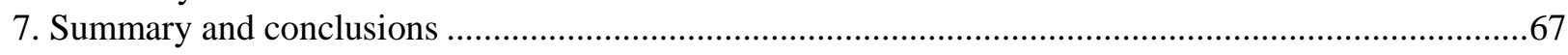

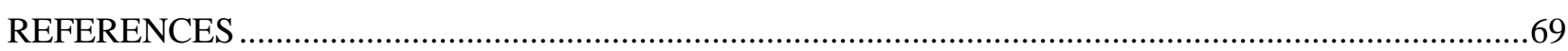

ANNEX A1. CHARACTERISTICS AND LIMITATIONS OF INCOME DATA FROM TAX RETURNS77

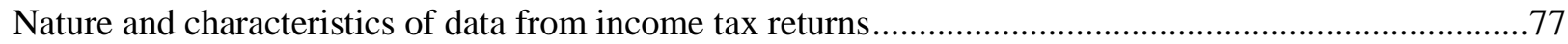

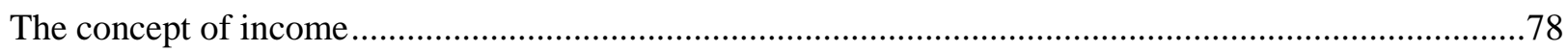

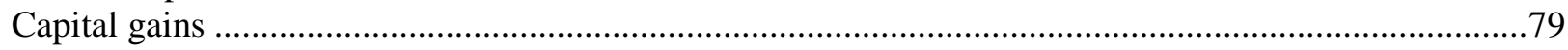

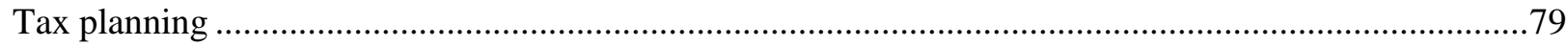

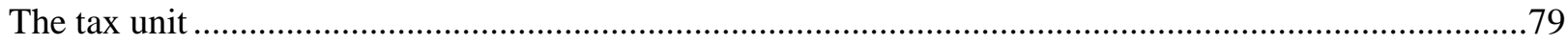

ANNEX A2. BREAKING DOWN THE ANNUAL AVERAGE INCOME GROWTH (AAIG) BY

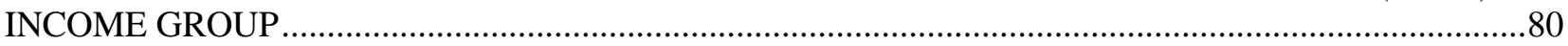

ANNEX A3. COUNTRY DETAILS OF THE COMPOSITION OF TOP INCOMES...............................82

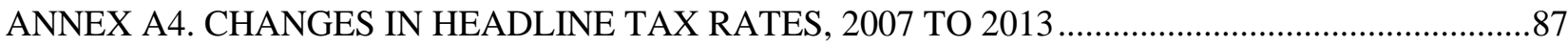




\section{Tables}

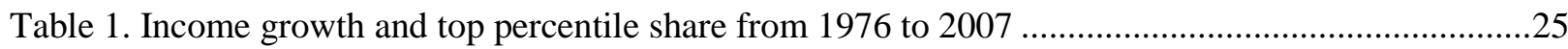

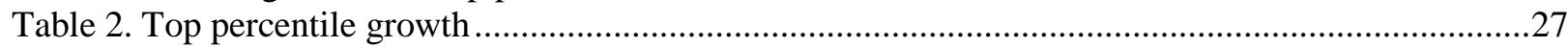

Table 3. Top income shares and the Gini coefficient in the United States, 1976 and 2006 ....................30

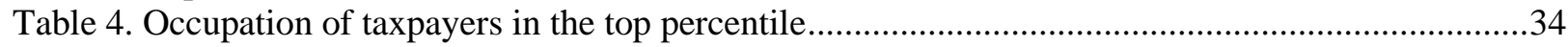

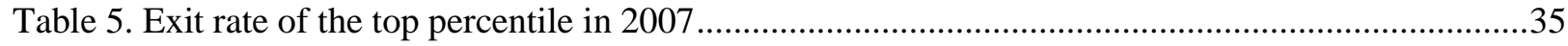

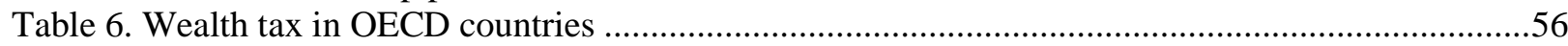

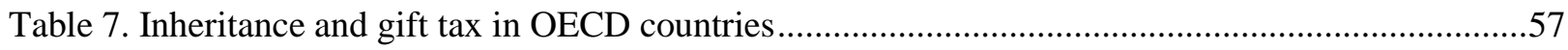

Table A3.1 Occupations of taxpayers in the top 0.1 percent in the United States ...................................86

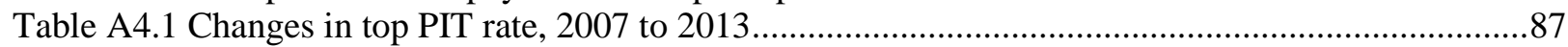

\section{Figures}

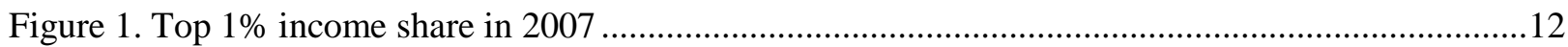

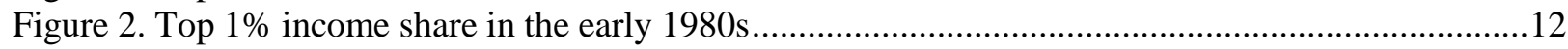

Figure 3. Trends in top 1\% income shares in English-speaking countries ............................................13

Figure 4. Top 1\% income share in other OECD countries ..................................................................15

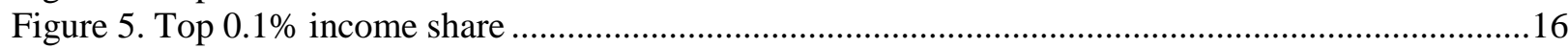

Figure 6. Trends in Top $0.01 \%$ income share ..................................................................................

Figure 7. Growth of income shares of different groups within the top 1\% percent (base year $=100) \ldots . .18$

Figure 8. Growth rate of the income of the top percentile and the rest of the population .........................20

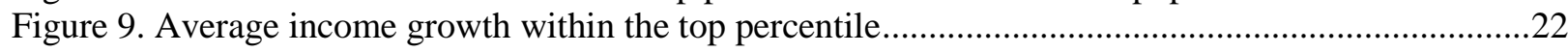

Figure 10. Annual income growth during the 2008 financial crisis....................................................23

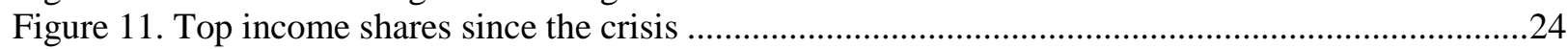

Figure 12. Share of income growth captured by income groups from 1976 to 2007 ...............................26

Figure 13. Top percentile income share and pre-tax Gini coefficient in the mid 2000s .........................29

Figure 14. Income composition of top incomes groups in the late 2000s...............................................32

Figure 15. Top $0.1 \%$ income share and composition in recent decades ................................................33

Figure 16. Exit rate from the top percentile over time ...........................................................................36

Figure 17. Income transmission across the distribution in Sweden ........................................................37

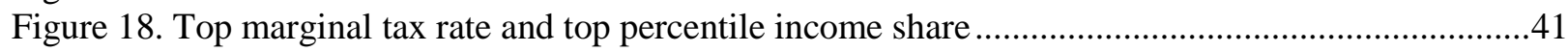

Figure 19. Top combined statutory personal income tax rate, 1981-2010..............................................44

Figure 20. Income threshold where the top combined statutory tax rate is levied..................................45

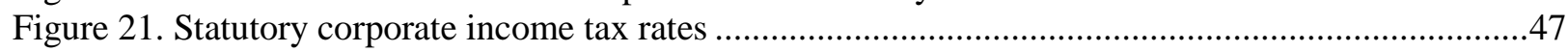

Figure 22. Overall statutory rates on dividend income for distributions of domestic source profits .........48

Figure 23. Estimated tax rate on dividend income from ordinary shares and interest (2011) .................49

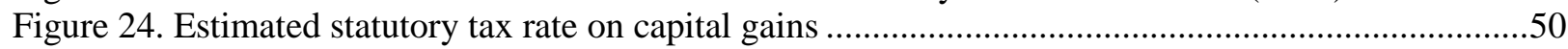

Figure 25.Top income share with capital gains , 1970-2010 .........................................................51

Figure 26. Capital gains as a share of total income …….....................................................................52

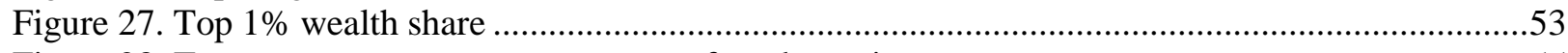

Figure 28. Taxes on property as a percentage of total taxation ........................................................55

Figure 29. Effective tax rate on bequests transmitted to direct descendant ............................................58

Figure A2.1 Share of income growth captured by income groups, 1976-2007 …..................................81

Figure A3.1 Income composition by fractile in Canada, 1970-2007 .................................................82

Figure A3.2 Income composition by fractile in the United States, 1970-2010 .........................................83

Figure A3.3 Income composition by fractile in France, 1970-2006 ......................................................84

Figure A3.4 Income composition by fractile in Italy, 1976-2008 .........................................................85 


\section{Boxes}

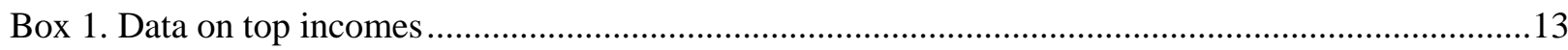

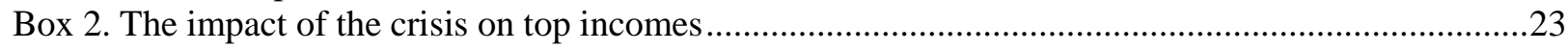

Box 3. Top incomes share and the axiomatic approach to inequality measurement …..........................28

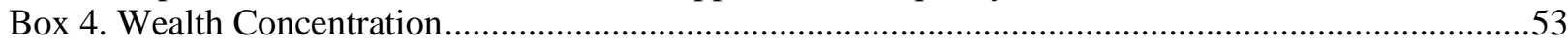

Box 5. The taxable income elasticity and the optimal tax rate ..............................................................61

This document and any map included herein are without prejudice to the status of or sovereignty over any territory, to the delimitation of international frontiers and boundaries and to the name of any territory, city or area.

The statistical data for Israel are supplied by and under the responsibility of the relevant Israeli authorities. The use of such data by the OECD is without prejudice to the status of the Golan Heights, East Jerusalem and Israeli settlements in the West Bank under the terms of international law. 
DELSA/ELSA/WD/SEM(2014)5

\section{TRENDS IN TOP INCOMES AND THEIR TAXATION IN OECD COUNTRIES}

\section{Introduction and summary}

1. This paper documents the changes in top income shares over the past three to four decades and reviews the factors that drive trends in top incomes, putting emphasis on the role of taxation. Previous studies have shown that the share of total income accruing to high earners has increased dramatically in a number of OECD countries over the last decades (e.g. Atkinson and Piketty, 2010). The latest overall OECD study on income distribution, Divided we Stand (OECD, 2011a) included a special chapter on trends in top incomes and further OECD work looked into this issue (Matthews, 2011, Hoeller, 2012). This work has shown that the upward trend towards income concentration at the top of the distribution is more marked in the United States and some other English-speaking countries, but income concentration has also been experienced also by other OECD countries, including some of those which used to be among the most egalitarian.

2. This paper extends and updates this previous work into the first years of the global financial and economic crisis, by looking at the most recent data on the shares and composition of top incomes. It looks at differences within top income groups for all OECD countries for which data are available. The paper makes use of the data collected by World Top Income Database (see Box 1). It also discusses the responsiveness of top incomes to different forms of taxation and the tax policy implications.

3. Changes in the share of total income accruing to top earners matter as they are likely to have a significant impact on the entire income distribution. Although top income shares do not provide any information on the shape of the middle and the bottom of the income distribution, an increased income share of top earners is likely to increase overall inequality, at least in terms of income before taxes.

4. Furthermore, although they are few in number, high income earners are very important for government revenue. In 2006, the top 1 percent of taxpayers paid approximately $40 \%$ of total personal income taxes in the United States (Mudry and Brian, 2009), and about 23\% in the United Kingdom (HMRC, 2012). At a time when fiscal consolidation is one of the top priorities for many governments, it is crucial to analyse the extent to which high earners are taxed. Efficient tax design and implementation also needs to take into account the behavioural responses triggered by taxation.

5. The report uses data derived from tax returns to analyse trends in the share of pre-tax personal income going to top income recipients (see Box 1). It begins with a cross-country analysis of trends of the different groups within the top percentile in the past three decades up to the first years of the global economic recession. Section 2 discusses the link between changes in top incomes and inequality trends, showing how the rise in top income shares may affect the rest of the distribution. Sections 3 and 4 review changes in the different income components of top earners and the possible explanations behind the top income trends. Sections 5 and 6 focus on trends in tax policy of relevance for top incomes, including wealth taxation and discuss the implications of different tax policy options for the behaviour of top incomes. 
6. The following key findings emerge:

- Top income shares have increased in many OECD countries in the past three decades, but there is considerable variation across countries in terms of the share and the pace of the increase. Shares of top income earners increased most in the United States and some other English-speaking countries but also saw a significant upward trend in some Nordic and Southern European countries, as well as Japan. The share of the top 1\% in total pre-tax incomes ranges from below $7 \%$ in Denmark and the Netherlands to almost $20 \%$ in the US.

- Over the past thirty years up to the crisis, real annual income growth of the top $1 \%$ has substantially outpaced growth of the bottom $99 \%$ incomes. As such, a significant fraction of growth - more than $20 \%$ of average income real annual growth - has been captured by the top percentile in English-speaking countries, up to $37 \%$ and $47 \%$ in Canada and the United States, respectively. The corresponding fraction was lower $-10 \%$ or below - in European countries for which data are available.

- In all countries, among the top incomes, the very top of the income distribution has benefited the most from the increasing concentration of income. Growth has been much more rapid for the top $0.01 \%$ income share than for any other, resulting in increased concentration of earnings at the very top of the income distribution.

- Income of top earners tends to be more volatile than those of the rest of the population, as top incomes are more sensitive to business cycle fluctuations than others. Actually, the higher up on the income ladder, the more incomes seem volatile. In this respect, the top $1-0.01 \%$ are more similar to the $99 \%$ of the population than to the extreme top of the income distribution, the richest $0.01 \%$. In other words, the volatility of the top percentile seems to be primarily driven by what is happening at the very top of the distribution.

- As a result, top incomes have tended to decline more than the rest during the initial years of the economic crisis (2007-2009) and the surge in top income shares came to a halt. That halt has, however, been only temporary in a number of countries, as recovery of top income shares has started already in 2010, and at a quicker pace than for other people, e.g. in Australia, Denmark, Norway, Sweden and the United States.

- Wages and salaries constitute the main part of income of top income earners for the top 10 to $1 \%$ earners (i.e. the "bottom 90\%" of the richest ten percent): it ranges from $70 \%$ in Italy to more than $85 \%$ in Canada. At the same time, with the exception of Canada, the further up the income ladder, the smaller the share of wages income, which becomes $40 \%$ or less of total income for the top $0.01 \%$. The surge in the income share of top incomes over the recent decades seems related to increasing labour compensation, although capital and business income have also experienced a rise in more recent years, especially in the US.

- Top marginal tax rates have declined considerably in most countries during the past decades and there is a strong negative correlation between the top marginal tax rates and the pre-tax shares of top incomes across OECD countries. In particular, the OECD-wide average top statutory personal income tax rate declined from $66 \%$ in 1981 to $42 \%$ in 2010 . Similarly, the statutory corporate income tax rate declined from $47 \%$ in 1981 to $25 \%$ in 2012 and taxes on dividend income for distributions of domestic source profits fell from $75 \%$ to $42 \%$.

- Other taxes affecting top incomes have been lowered, too in the past decades. Several countries abolished or decreased net wealth taxes and inheritance taxes. Net wealth is only taxed in a few 
OECD countries and taxes on immovable property represent a small percentage of overall taxation. While wealth taxes are criticised by some because they are considered to be a form of double or triple taxation, decreasing marginal tax rates for top incomes and tax exemption on capital income, mainly capital gains, may imply that top incomes could accumulate more capital and wealth and transmit it through bequests.

- Capital gains are concentrated at the top of the income distribution. Including them in pre-tax income would increase estimates of the top income shares by between 1 and 3 percentage points. Statutory tax rates on capital gains on shares range from 12\% in Belgium to more than $55 \%$ in Greece and Denmark. In around half of OECD countries, capital gains made on shares are only subject to the corporate income tax and not to personal tax.

- While the elasticity of taxable income appears to be higher for high-income individuals, it remains methodologically difficult to assess an optimal tax rate for top earners based on their estimated elasticity. On the other hand, part of the response to changes in taxation from top earners may come from greater opportunities for tax optimisation (increased income shifting and tax avoidance), which therefore should be addressed by policy measures in addition to reviewing top tax rates.

- Taxation of top income earners tends to involve difficult trade-offs between equity and efficiency objectives. It is often argued that lower top marginal tax rates may promote higher economic growth. However, the associated increased inequality may lead to inequality traps, i.e. persistent differences in income, wealth and power between socio-economic groups, with not only social but also long-term economic effects.

\section{Trends in top incomes}

\subsection{Top percentile income share in recent decades}

7. The share of pre-tax income going to top earners differs widely over time and across OECD countries. While a growing literature focuses on the evolution of top incomes and their driving forces over the entire $20^{\text {th }}$ century, as reviewed in Atkinson, Piketty and Saez (2011), in this paper the emphasis is put on trends over the three to four most recent decades only.

8. There is a wide cross-country variation in the share of total income going to the top $1 \%$ of earners at the latest date available, around 2010 (Figure 1). Though considerable care is needed when comparing top income share levels across countries (see Box 1), some clear-cut differences may be observed. Top earners capture nowadays a larger fraction of total pre-tax income in most English-speaking countries (especially in Northern America and the United Kingdom) than in continental Europe and the Nordic countries. The income share accruing to the top percentile is well above 10 percent in the United States, Canada, and in the United Kingdom. On the other hand, in the Nordic countries, but also in the Netherlands and New Zealand, top 1\% shares are below 8 percent. 
Figure 1. Top 1\% income share in 2012 (or closest year)

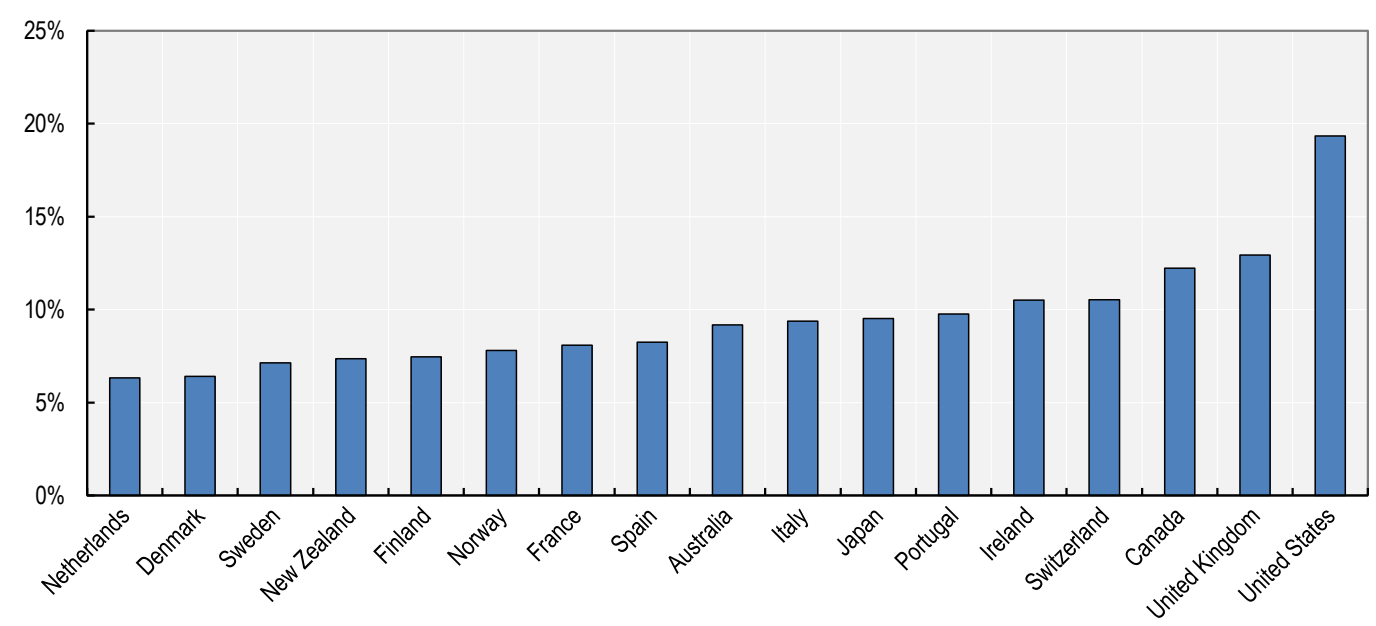

Note: Data refer to 2012 for Sweden and the United States; 2011 for Norway and the United Kingdom; 2009 for Finland, France, Italy and Switzerland; 2007 for Germany; 2005 for Portugal; and 2010 for the remaining countries. Incomes refer to pre-tax incomes and exclude capital gains.

Source: World Top Incomes Database.

9. Figure 2 shows that the country ranking used to be quite different some 30 years ago. In the early 1980s the share of total income accruing to the top $1 \%$ of earners was below ten percent in all OECD countries except Germany where it was highest. This was actually the result of a long-term trend towards declining inequality. During the post-war period the income share of high earners decreased indeed to a historically low level in all developed countries. As a result of this worldwide trend the cross-country variation in top income shares was relatively low. In the early 1980s the dispersion of income was not systematically stronger in English-speaking countries than in Continental and Southern Europe. Top percentile income shares were higher in Germany and in Switzerland than in the United States. At the same time, Nordic countries already displayed the lowest dispersion of income at the top end of the distribution, but so did Australia and Portugal.

Figure 2. Top $1 \%$ income share in the early 1980 s

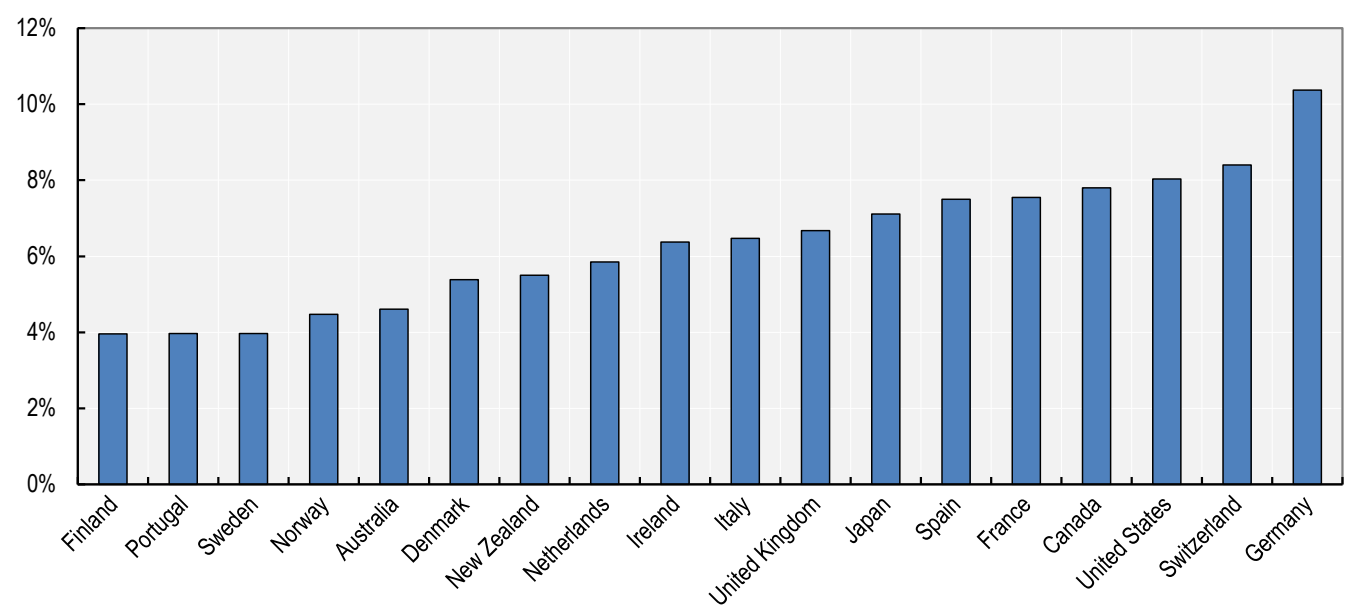

Note: Data are for 1981 for all countries except Germany (1980). Incomes refer to pre-tax incomes. Incomes exclude capital gains.

Source: World Top Incomes Database 
10. Over the recent decades the share of market income flowing to the top percentile group has risen strongly in many OECD countries, though not in all. The evolution in top income shares has been quite diverse across OECD countries and resulted in important cross-country variation. Figure 3 shows the development of the shares of total pre-tax income going to the top percentile group from 1975 to 2010 in English-speaking countries. In spite of quite a significant year-to-year variability, some overall trends can be observed. The shares of total income going to the top percentile have risen sharply over the last three decades. In the United States and the United Kingdom they more than doubled from 1980 to 2010. In other English-speaking countries, there is also a tendency for more concentration in income at the top, though less marked. The global crisis in 2008 has brought about a fall in top income shares though in many countries, this fall appears to be of temporary nature. The impact of the crisis on top incomes is further discussed in Box 2 below.

\section{Figure 3. Trends in top 1\% income shares in English-speaking countries}

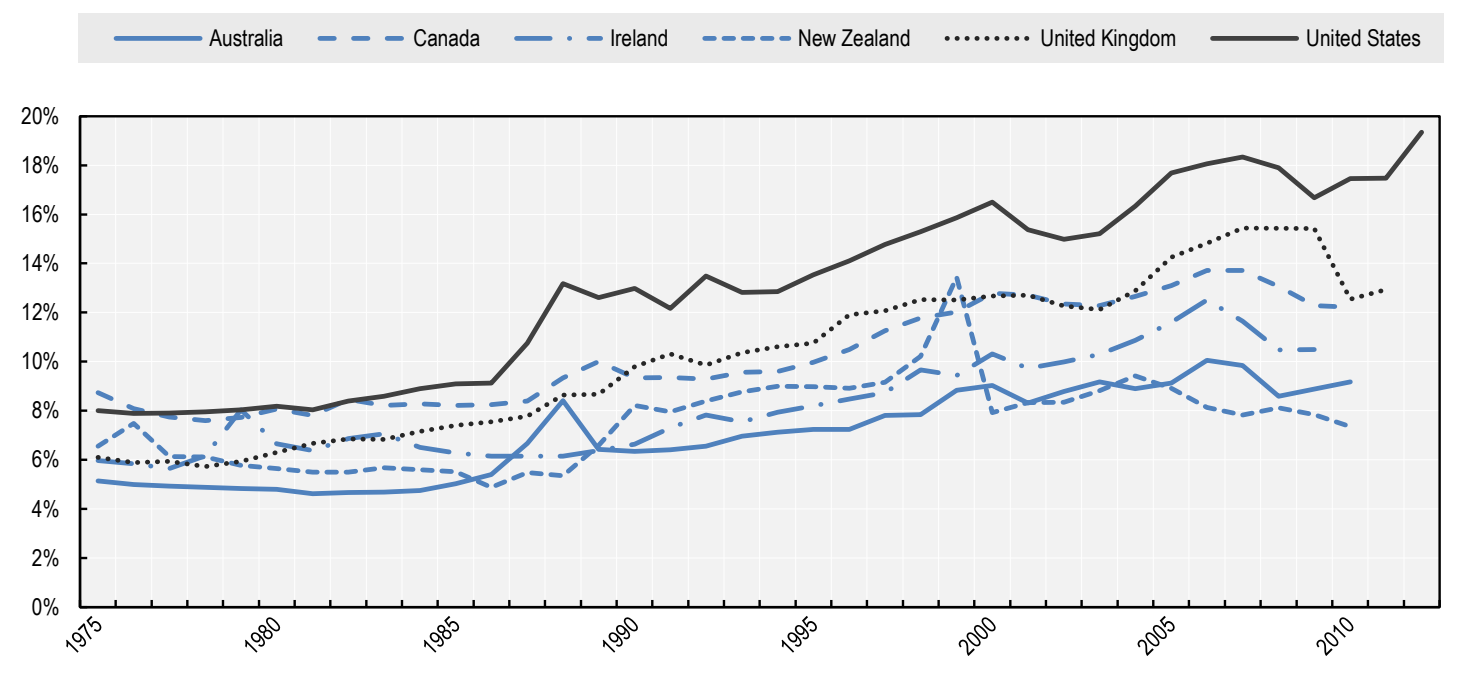

Note: Incomes refer to pre-tax incomes. Capital gains are excluded.

Source: World Top Incomes Database

11. The cross-country variation among the English-speaking countries has increased since the mid1970s. The top percentile income share has grown at a quicker pace in the United States and in the United Kingdom than in the other countries. While in 1975 the top 1\% income share was three percentage points higher in the US than in Australia, the difference is more than eight points in 2010. The increase in top 1\% income shares started in the mid-1980s in the United States and the United Kingdom, but only in the 1990s in Canada and Ireland.

\section{Box 1. Data on top incomes}

This report makes extensive use of data from the World Top Incomes Database prepared by Facundo Alvaredo, Tony Atkinson, Thomas Piketty, Emmanuel Saez and various collaborators. The World top incomes database (http://topincomes.g-mond.parisschoolofeconomics.eu/) includes data on top incomes for 18 OECD countries (Australia, Canada, Denmark, Finland, France, Germany, Ireland, Italy, Japan, Netherlands, New Zealand, Norway, Portugal, Spain, Sweden, Switzerland, United Kingdom and United States.)

Atkinson, Piketty and Saez (2011) explain comprehensively the methodology followed so as to estimate income shares using data from tax returns. Tabulations published by tax authorities typically report the number of tax payers per income bracket and their corresponding income, which are usually broken down by income source. Tax data must then be combined with external estimates of the total population and the total income to estimate income shares. This work involved a number of steps: 
- First, the number of tax payers has to be related to the size of the adult population. At the beginning of the $20^{\text {th }}$ century (when income tax was implemented in most European countries) only a small fraction of the population was subject to the income tax (around 0.05\% in the UK in 1911-1912, for instance). In countries where the tax unit is the individual (this is the case for Canada, New Zealand from 1963, or the United Kingdom from 1990), the natural control is the adult population. In countries where the tax unit is the family, the control should be the number of families.

- The income of taxpayers (the numerator of the top income share) needs to be related to the total household income (the denominator of the top income share). Different methods of imputation are used, which may have an effect on comparability across countries and over time. However, the rise in the share of individuals in recent decades that file tax returns makes this less of a problem.

- As the raw data usually display the number of taxpayers in each income group, which generally do not correspond to the percentage groups (like, say, the top percentile), some method of interpolation is needed to get statistics such as top income shares. The usual statistic approach is to assume that the income distribution follows a Pareto distribution. This law is known to approximate very well the top tail of the income distribution. Typically, errors are very small if the number of brackets is large enough, so this step is not a major source of concern.

The main limitation of tax data is that tax-exempt income is typically not reported and consequently left out of the analysis. This is likely to affect the analysis of top incomes as a growing share of capital income is tax exempted or a withholding tax is levied (and therefore not reported) nowadays (Atkinson et al., 2011). Therefore, considerable care is needed in comparing top income shares between countries and over time in a single country. Measurement issues include cross-country differences (and changes over time) in the concept of income that is measured; the availability of data for income measures; the extent of tax planning and tax evasion; and the definition of the tax unit. More detailed information is described in Annex A1.

12. Figure 4 (Panels A and B) displays the top percentile shares for Nordic and Southern European countries. The data show a clear upward trend albeit less marked than in English-speaking countries. There has been indeed a modest but significant increase in the top percentile shares in total income from the early 1980s onwards in both southern European and Nordic countries. The top 1\% shares increased by a factor of 1.7 from 1980 to the late 2000s in Finland, Norway ${ }^{1}$ and Sweden. In the Nordic countries, the growth in top incomes occurred particularly during the 1990s.

13. Top 1\% shares also rose steadily in the Southern European countries since the early 1980s and up to the crisis. The top 1\% share increased in Spain from $7.5 \%$ in 1981 to $9 \%$ in 2006, i.e. by about 20\%, but has since then declined progressively. A similar trend can be observed for Italy where the top $1 \%$ share increased by $40 \%$ since 1980 and is slightly falling since 2008. In Portugal, the share increased steadily from below 7\% in 1989 to close to 10\% in 2005 (no more recent data are available).

14. The tendency for increasingly growing top income shares is less marked in the remaining OECD countries covered by data. Figure 4 (Panel C) shows the top percentile group's share for France, Germany, Japan, the Netherlands and Switzerland. In contrast to English speaking countries there is no clear constant upward trend over the whole period. That said, top percentile shares have gone up modestly from the mid 1990 up to the crisis in France (by 15\%), and in Japan and Switzerland (by 30\%). Unfortunately, no comparable data are available for Germany beyond 1999. That said, available estimates on an alternative and more comprehensive income definition (namely including capital gains) suggest that top $1 \%$ income shares have remained rather stable at a relatively high level (10-12\%) in Germany ${ }^{2}$.

1 See section 1.3 for a discussion on the top income share fluctuations for Norway.

2 For comparison, top 1\% shares were around 1 percentage point higher in Germany in 1998 when assessed including capital gains than on the standard definition which excludes capital gains. 
Figure 4. Top $1 \%$ income shares in other OECD countries

\section{Panel A}

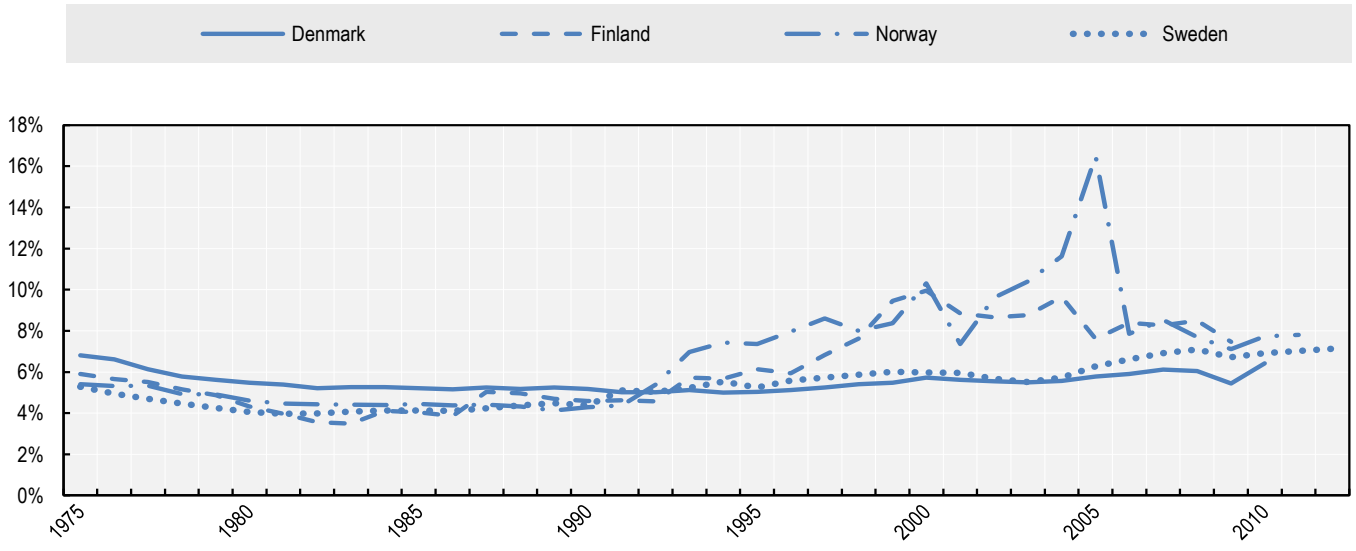

Panel B

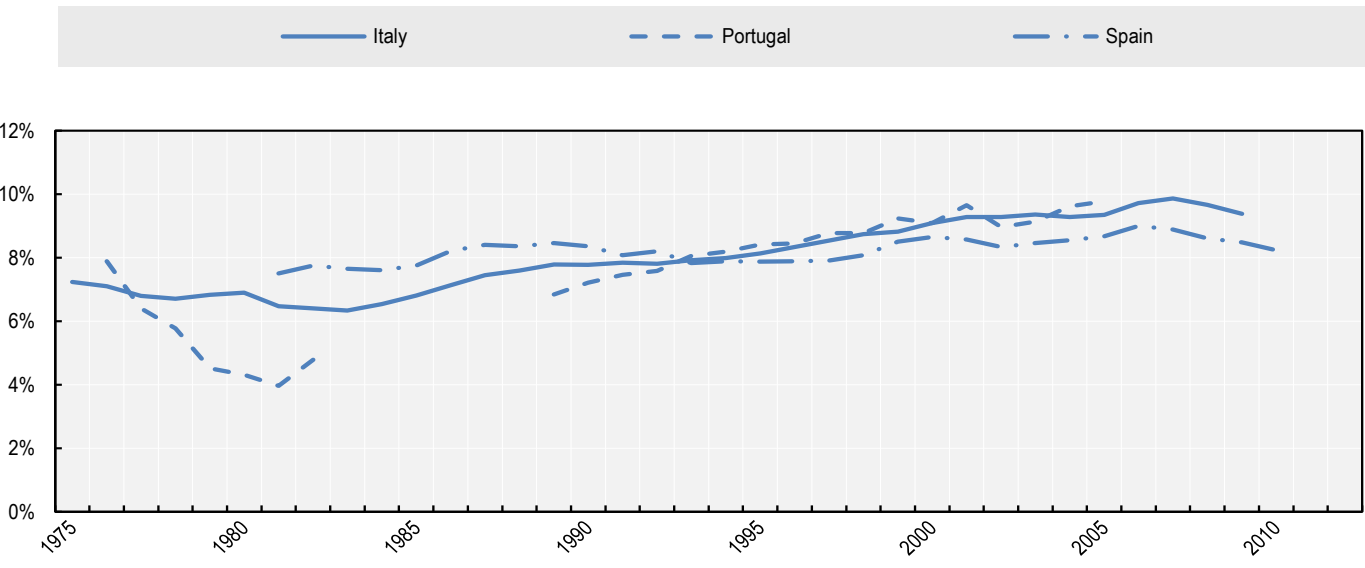

Panel C

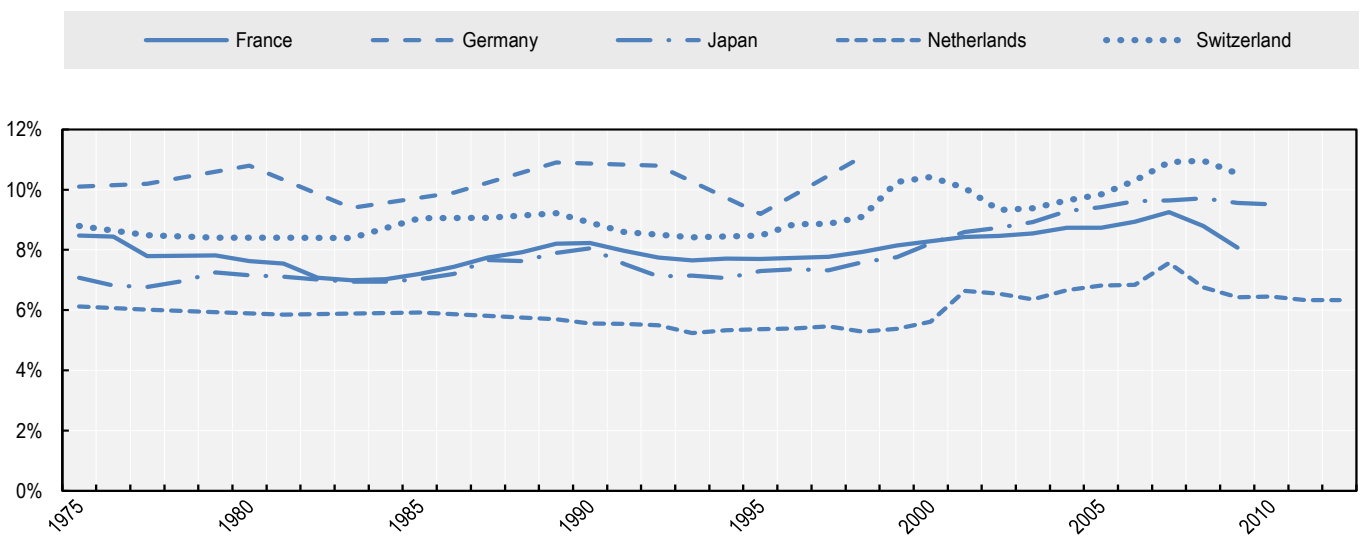

Note: Incomes refer to pre-tax incomes. Capital gains are excluded.

Source: World Top Incomes Database 


\subsection{Trends within the top percentile}

15. Increased dispersion of income occurred in recent decades in a number of OECD countries in which the share of income accruing to the top percentile has risen dramatically. In order to fully grasp the distributional changes that took place in the last three decades, it is worth looking at what happened within the top percentile.

16. In the mid-1970s, between 1 and 3 percent of total income accrued to the top $0.1 \%$ of earners in countries for which data are available (Figure 5). There was no significant difference between Englishspeaking countries and the European countries at that time, while the share of total income going to very high earners is today much higher in the English-speaking countries than in other OECD countries

Figure 5. Top $0.1 \%$ income shares
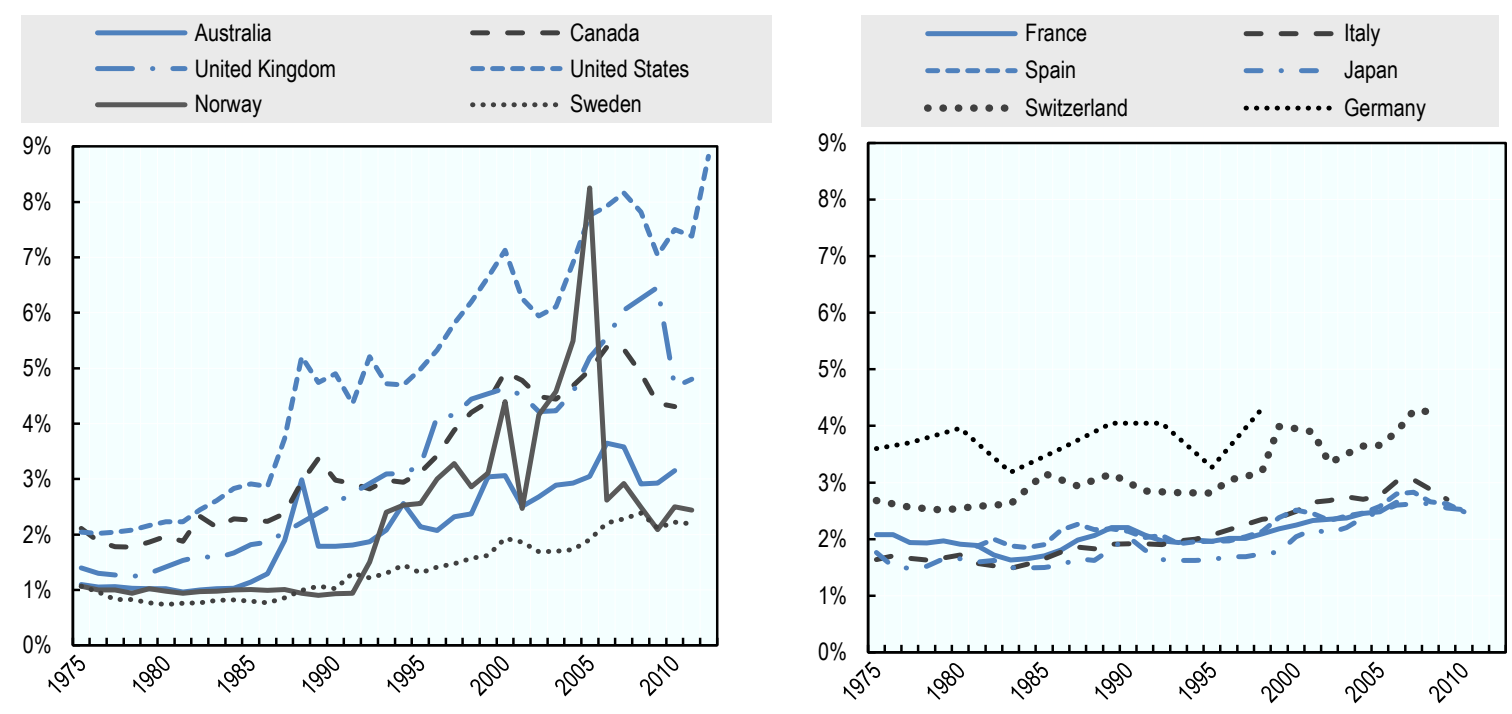

Note: Incomes refer to pre-tax incomes. Capital gains are excluded.

Source: World Top Incomes Database

17. From the early 1980s onwards the English-speaking countries have seen a dramatic rise in the share of total income accruing to the very top of the income distribution. Over the last three decades, the top $0.1 \%$ income share has been multiplied by about four in the United Kingdom and the United States, and by more than three in Australia. In the remaining countries the trend is less marked but still significant in some countries. The share accruing to the top $0.1 \%$ has doubled in the Nordic countries over the period, and has gone up in the other countries, albeit to a lesser extent. In these countries, the top $0.1 \%$ share starts growing typically in the early 1990s while in all English speaking countries the rise starts in the late 1980s.

18. The increase in top $0.01 \%$ income share is even more pronounced than for other income groups. This is shown in Figure 6. The share of income accruing to this group has been multiplied by more than 6 in the United States. Even in France, where the top percentile and top 0.1 shares have been relatively stable over the period, the share going to the top $0.01 \%$ has gone up by $50 \%$. The very top of the income distribution seems to benefit the most from increasing concentration of income. Growth of income shares has been much more rapid for this group than for any other, resulting in increased concentration of income at the very top of the income distribution. 
Figure 6. Trends in Top $0.01 \%$ income shares
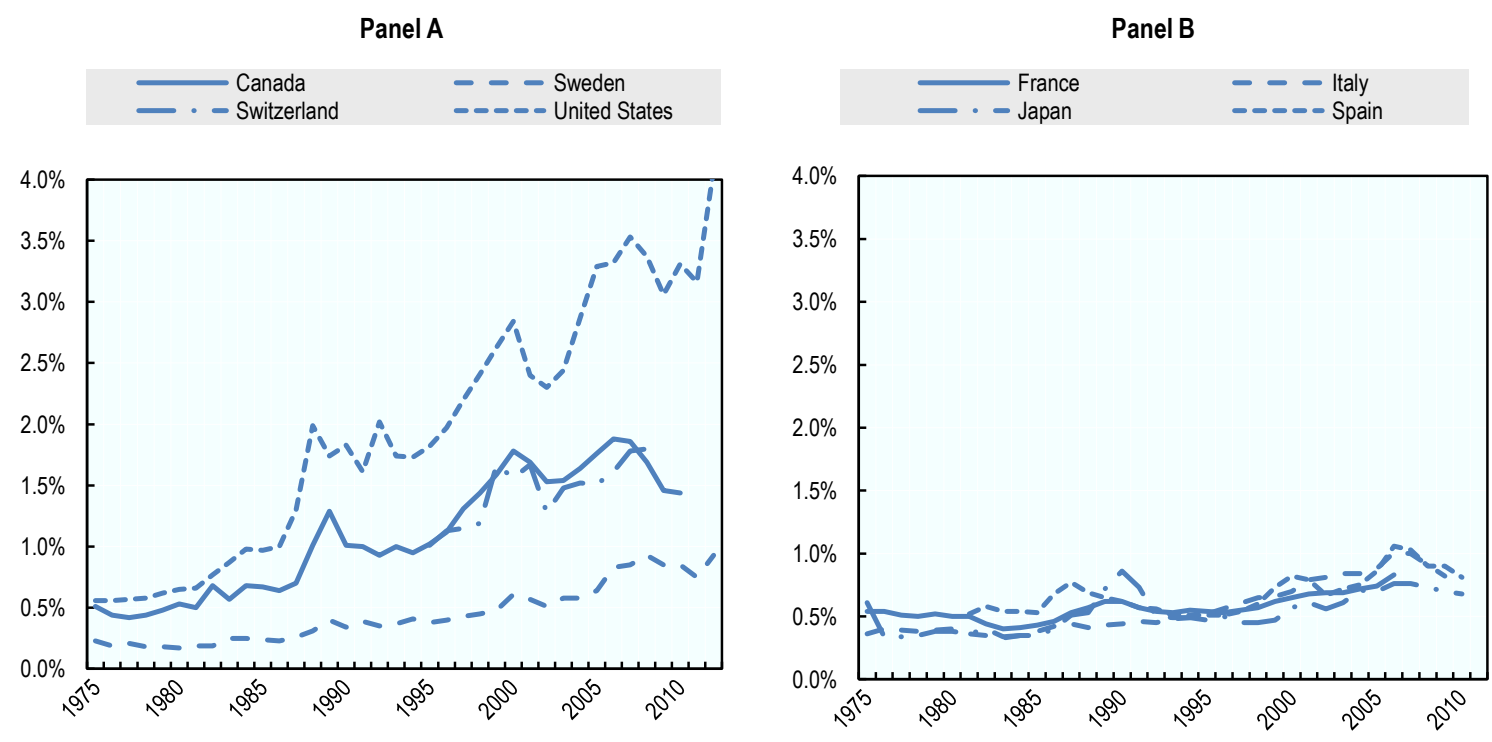

Note: Incomes refer to pre-tax incomes. Capital gains are excluded.

Source: World Top Incomes Database

19. The top percentile is not a homogenous group and the increase in the top percentile income share may be driven by the rise in the share going to the very top earners. Figure 7 splits the top percentile into three sub-groups - the richest $0.01 \%$, the top $0.1-0.01 \%$ and the top $1-0.1 \%$ of earners (in other words, the "bottom 90\%" of the top percentile ) - and displays the evolution of those sub-groups over the last four decades. Figures are normalised to the starting year $(1970=100)$.

20. Growth was similar for the three sub-groups in the 1970s up to the early 1980s. Growth rates generally started to diverge when the income share going to top percentile started rising. In countries where the increase in the top percentile has been the most pronounced (e.g. the United States, Canada, and to a lesser extent, Sweden), the fraction of total income flowing to very top groups (top $0.1-0.01 \%$ and top $0.01 \%$ ) has grown much more rapidly than the share going to the bottom of the top percentile. Even in countries where the growth in top incomes remains moderate, such as Italy, France or Spain, the fraction of income going to the very top of the distribution started to increase from the mid-1990s onwards. In Japan, the share of income accruing to the three sub-groups appears to have evolved similarly, though the top $0.01 \%$ income share is more volatile. In general, the richest benefited the most from increased top $1 \%$ income share. To a certain extent, the increase in the top percentile income share seems to be substantially driven by concentration of income at the very top of the top percentile. 
Figure 7. Growth of income shares of different groups within the top $1 \%$ percent (base year $=100$ )

- Top $1-0.1 \%$

Canada
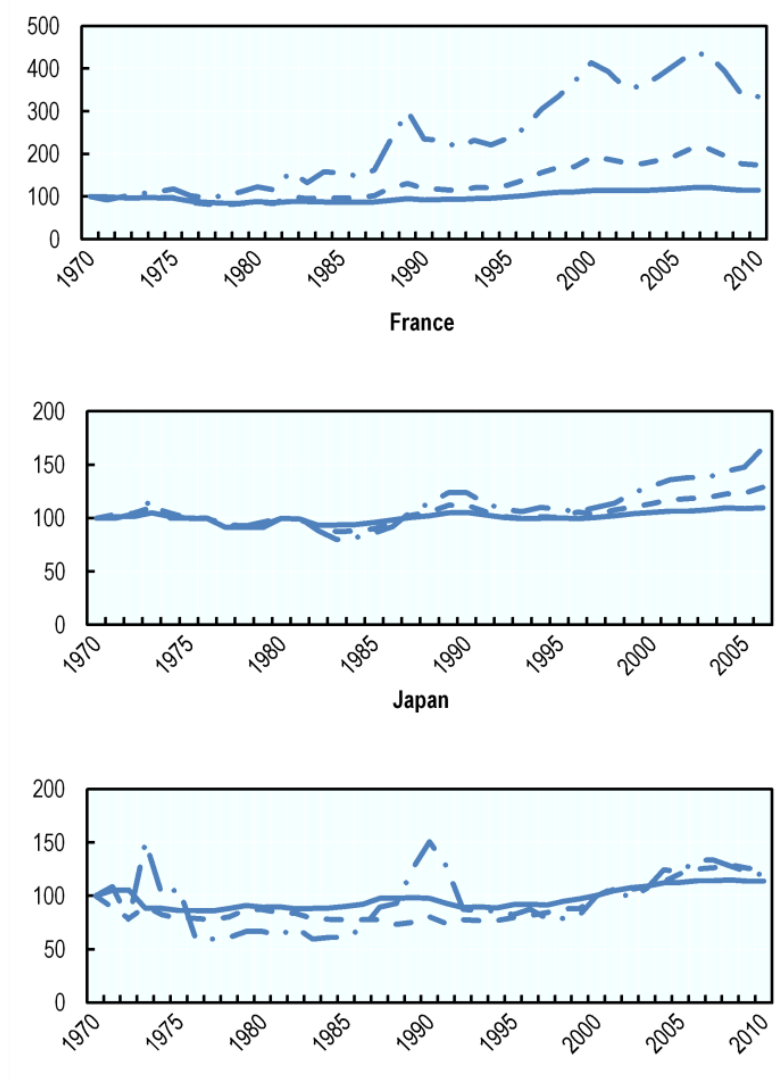

Sweden

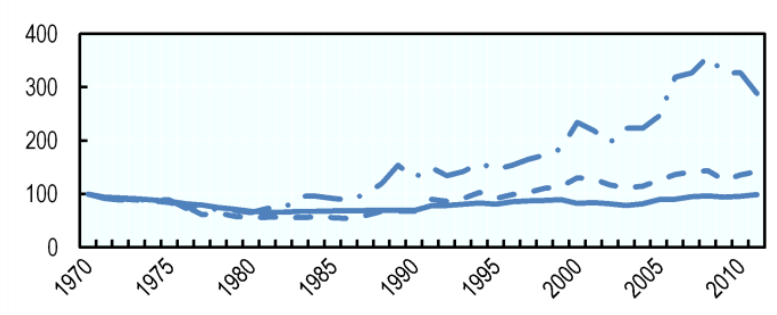

Denmark

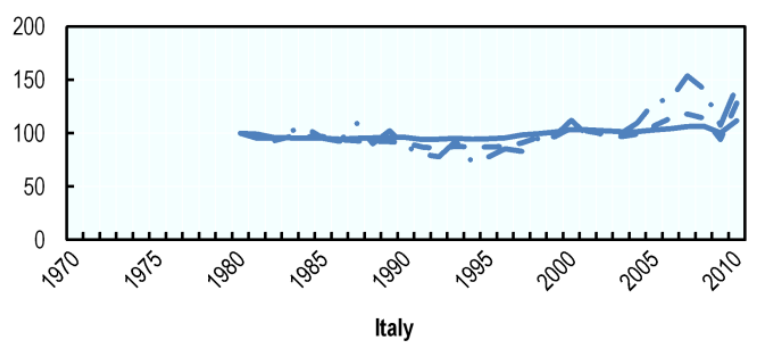

Italy
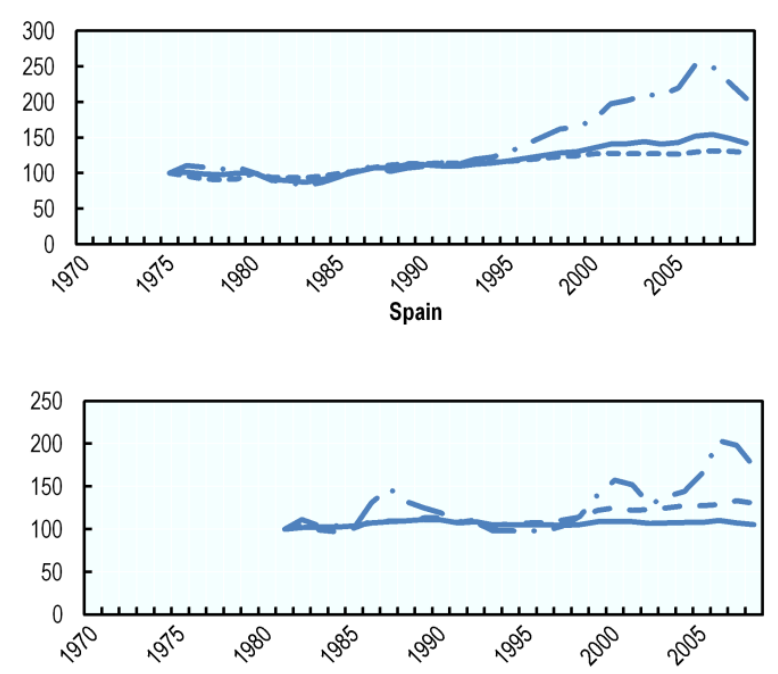

Switzerland

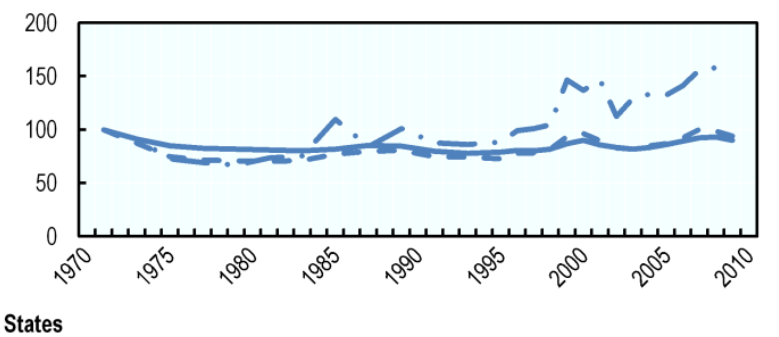

United States

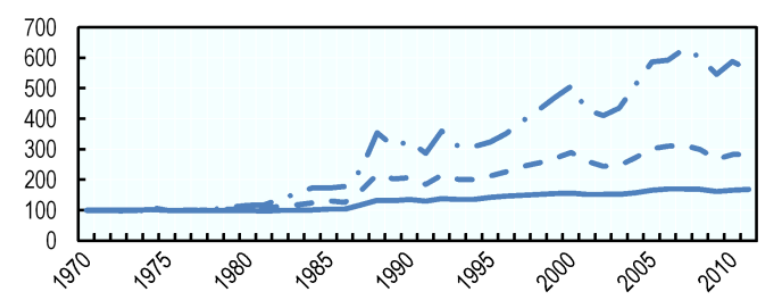

Note: Incomes refer to pre-tax incomes. Income shares are set to 100 in 1970 or in the first available year.

Source: World Top Incomes Database 


\subsection{Volatility of top incomes and cyclical fluctuations}

21. While undoubtedly following an upward trend in many countries, the top $1 \%$ income share did not grow at a continuous rate over the whole period. The income received by the top earners generally tends to be volatile and there is quite a large year-to-year variability in many countries, as for instance in New Zealand where the top 1\% jumps up from about $10 \%$ in 1998 to over $13.5 \%$ in 1999, before falling down to $8.3 \%$ in 2000. This holds not only for English-speaking countries but also for the bulk of European countries ${ }^{3}$. For instance, the top $1 \%$ share fluctuates widely in Norway and, to a lesser extent, in Finland. In the United States the top $1 \%$ share goes up sharply in the mid-1980s before remaining fairly constant in the early 1990s. It then goes up at a steady pace until the early 2000s, experiencing then a drop followed by a strong recovery in the 2000s until the financial crisis. Despite the upward trend, the income share going to the top $1 \%$ seems to vary cyclically.

22. Figure 8 shows that income of top earners tends to be more volatile than those of the rest of the population. The year-to-year variability is generally higher (in absolute value) for the top percentile than for the rest of the population. While differences in variability were less apparent in the 1970s, from the early 1980s onwards - or even later in some countries like Norway - the incomes of top earners have been fluctuating widely. Indeed, the average income of the top percentile goes up (down) at a faster pace than the rest of the population in period of economic expansion (contraction). This pattern is observed in all countries for which data are available.

23. Volatility may partly be related with changes in the income tax structure, as the data that are used measure taxable income. Changes in the tax structure trigger indeed a set of behavioural responses that are likely to affect reported income. Those behavioural responses are generally concentrated in the top of the income distribution, since high earners are usually affected more strongly by tax changes and at the same time have more opportunities to shelter income from the personal income tax ${ }^{4}$. Aaberge and Atkinson (2010) show that the top income share's fluctuations in the early 2000s in Norway are to be put down to income shifting, i.e. reclassification of income aiming at minimising the tax burden. The implementation of a permanent tax on dividends from 2006 gave strong incentives for managers to increase dividends in 2005 , resulting in a dramatic increase in the average income of top earners in 2005 and subsequently a sharp drop in 2006. Goolsbee (2000) shows that for executives an important part of the response to the 1993 tax rate increase in the US was due to a timing in the realisation of stock options. Similarly, Slemrod (1996) and Gordon and Slemrod (2000) hold that the dramatic rise in top income growth in the late 1980s was due primarily to a shift of taxable income from the corporate sector to the individual income tax base as the Tax Reform Act of 1986 reduced income tax rates.

24. High volatility may also be due to the income of top earners being disproportionally affected by business cycles. Studying top incomes in the United States, Parker and Vissing-Jorgensen (2010) highlight that over the last three decades the incomes of top earners have become more sensitive to economic expansions and recessions than those of average earners. Before the 1980s, the cyclicality of top incomes was slightly less than average. The picture looks different after 1982. According to their computations, the incomes of the top percentile were on average 2.4 times more cyclical than those of average earners. Figure 8 shows that in the United States the average income of the top percentile grew at a quicker pace than the average income of the rest of the population during economic expansions (the late 1990s and the period after the dot-com bubble burst and until the financial crisis) and conversely decreased more sharply during downturns.

\footnotetext{
$3 \quad$ For the Netherlands, Germany and Switzerland it is less obvious, but data are partly only available every 3 to 4 years, which hinders grasping the year-to-year variability.

$4 \quad$ This will be further investigated in the section devoted on the impact of taxation on top incomes.
} 
DELSA/ELSA/WD/SEM(2014)5

Figure 8. Growth rate of the income of the top percentile and the rest of the population

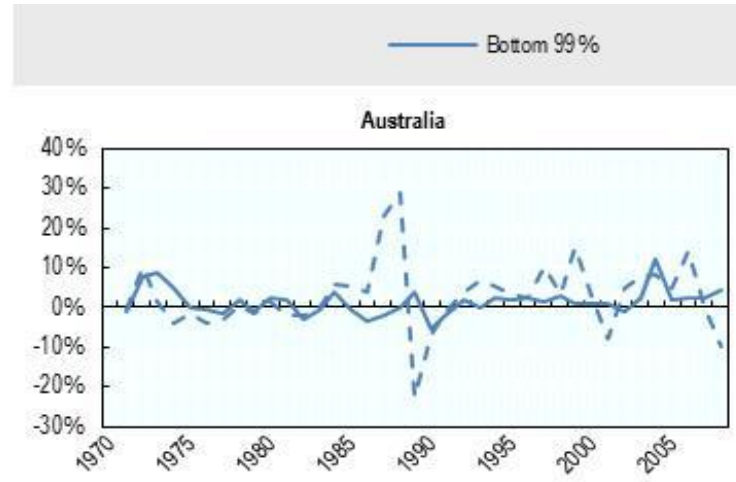

- - - Top $1 \%$
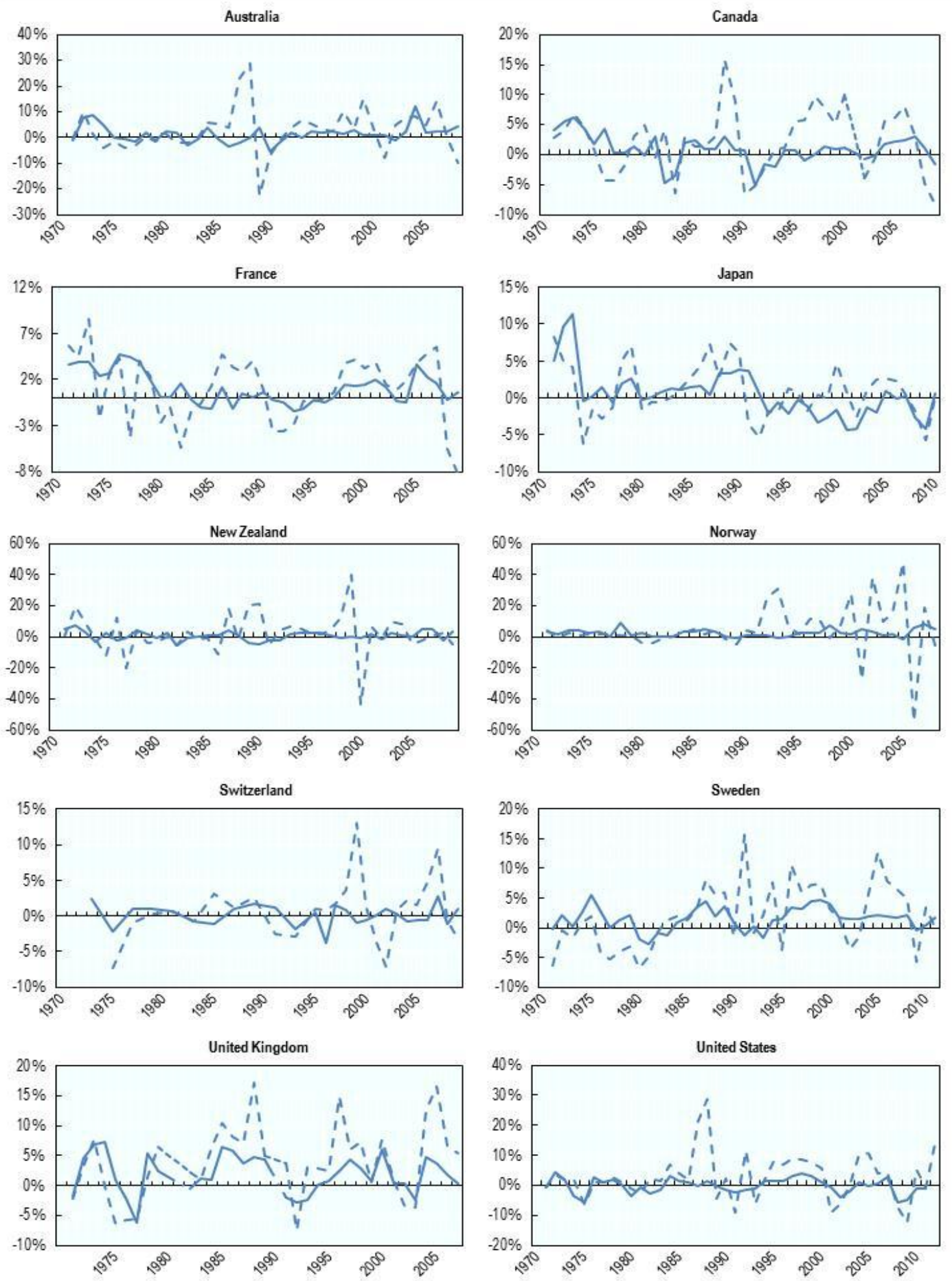

Source: World Top Incomes Database

20 
25. As high earners receive a large part of their pre-tax income from capital income, shocks are likely to affect their income more strongly than the rest of the population's. Capital income tends to be prone to cyclical variation, while wages are usually more rigid in the short run. Unsurprisingly, including capital gains in the definition of income increases volatility (see Figure 25, section 5). The impact is less noticeable in Canada than for the other three countries that have data available.

26. High cyclicality cannot however be put down solely to capital income fluctuations. A growing fraction of the income of top earners comes from wages and salaries (in many countries, bonuses are counted within wage income). However, over the last three decades wage and salary income of top earners has also been highly cyclical in the US. Parker and Vissing-Jorgensen (2010) show that while wage income of top earners was almost acyclical before 1982, it has become highly cyclical since the 1980s. Sensitivity to business cycles is therefore not driven entirely by capital income, but is also due to fluctuations in wages income.

27. The fluctuation of top income shares is even more striking when looking at groups further up on the income ladder. Figure 9 shows the annual income growth for the top $0.01 \%$ of earners and the rest of the top percentile. The incomes of the top $0.01 \%$ of earners fluctuate even more widely than those of the top $1-0.01 \%$. In Canada and in the US, the top $1-0.01 \%$ grows at a more steady pace and seem to be less affected by business cycles, in contrast with the share of taxable income flowing to the top $0.01 \%$ which is extremely sensitive to business cycle and tax reforms. In this respect, the top $1-0.01 \%$ are more similar to the $99 \%$ of the population than to the very top of the income distribution. The volatility of the top percentile seems to be primarily driven by what is happening at the very top of the distribution. 
Figure 9. Average real income growth within the top percentile
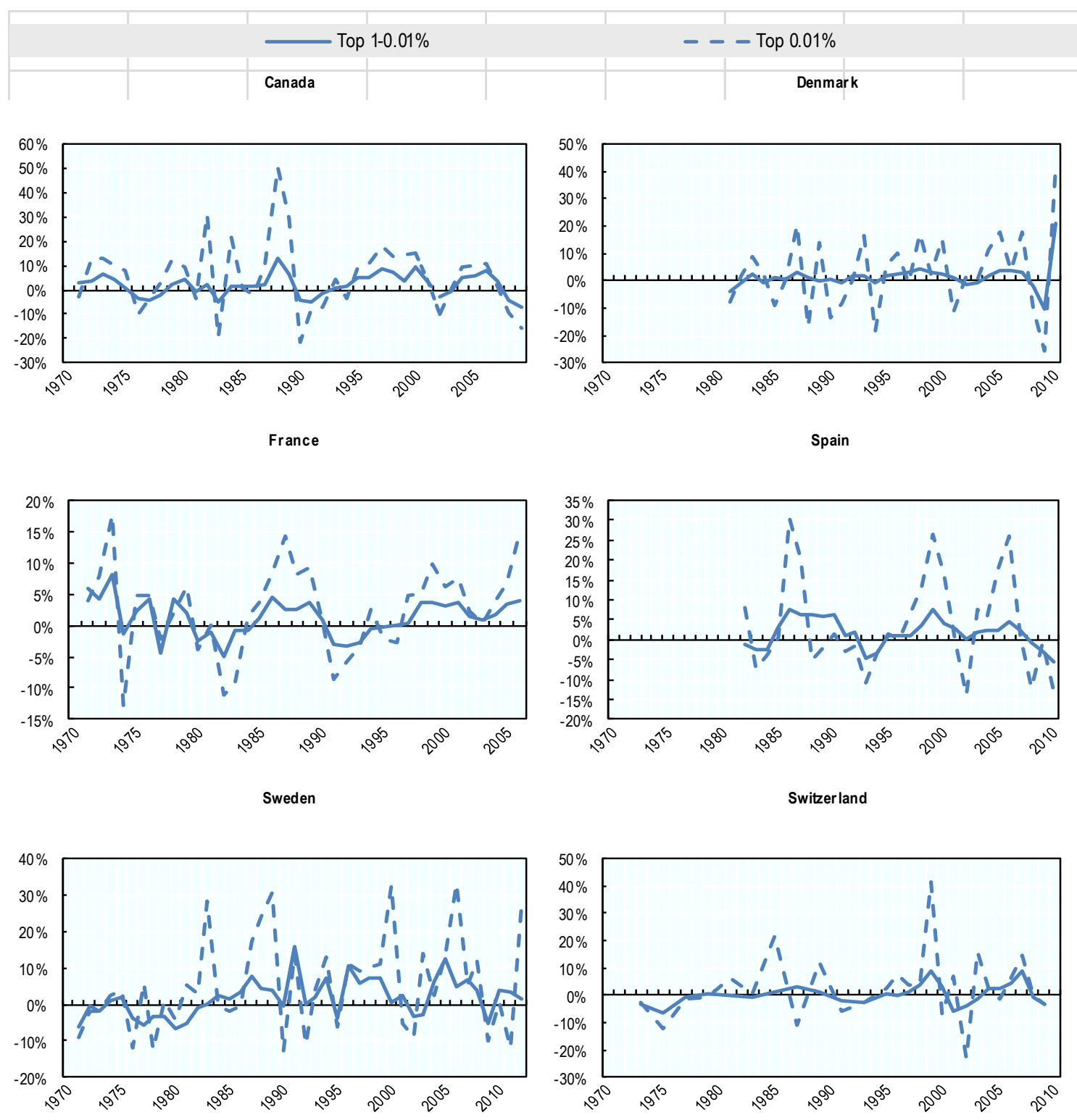

United States

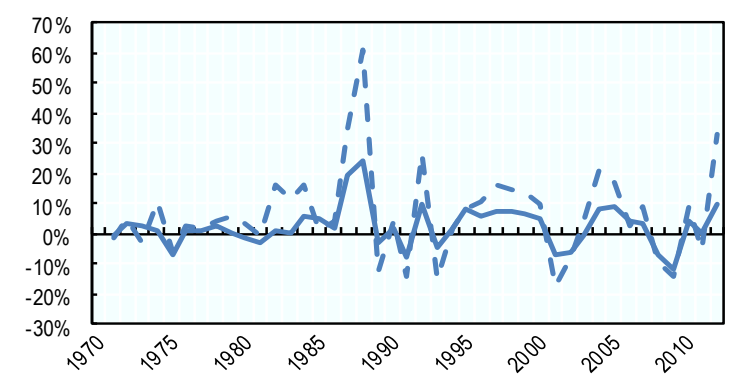

Note: Incomes refer to pre-tax incomes.

Source: World Top Income Database 


\section{Box 2. The impact of the crisis on top incomes}

The period before the 2008 financial crisis saw an increase in the share of total income flowing to high earners in most countries. Over the years 2008 and 2009 the top 1\% share decreased significantly in countries for which data are available. The average incomes of top $1 \%$ of earners declined fiercely. As shown in figure 10, top earners experienced indeed a higher income shock than the bulk of the population, thereby reinforcing the idea that top incomes are more cyclically sensitive than others.

Figure 10. Annual income growth during the 2008-2009 financial crisis

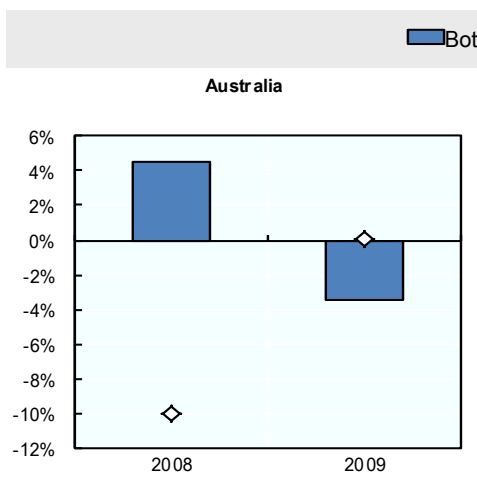

\section{$\diamond$ Top $1 \%$}
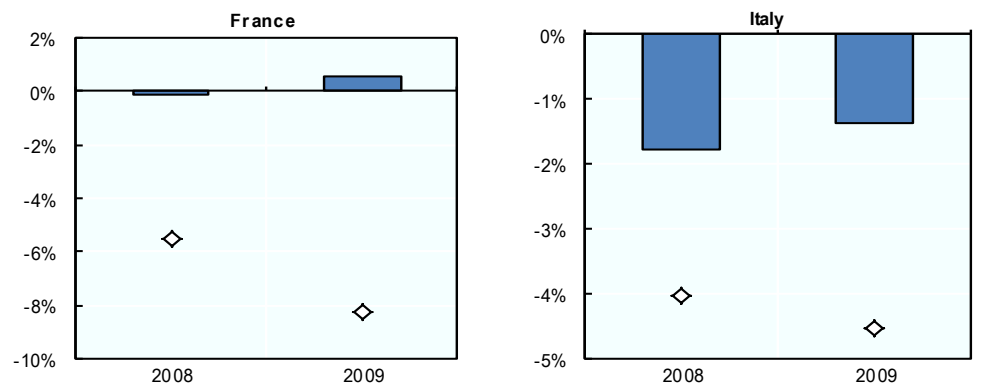

Canada
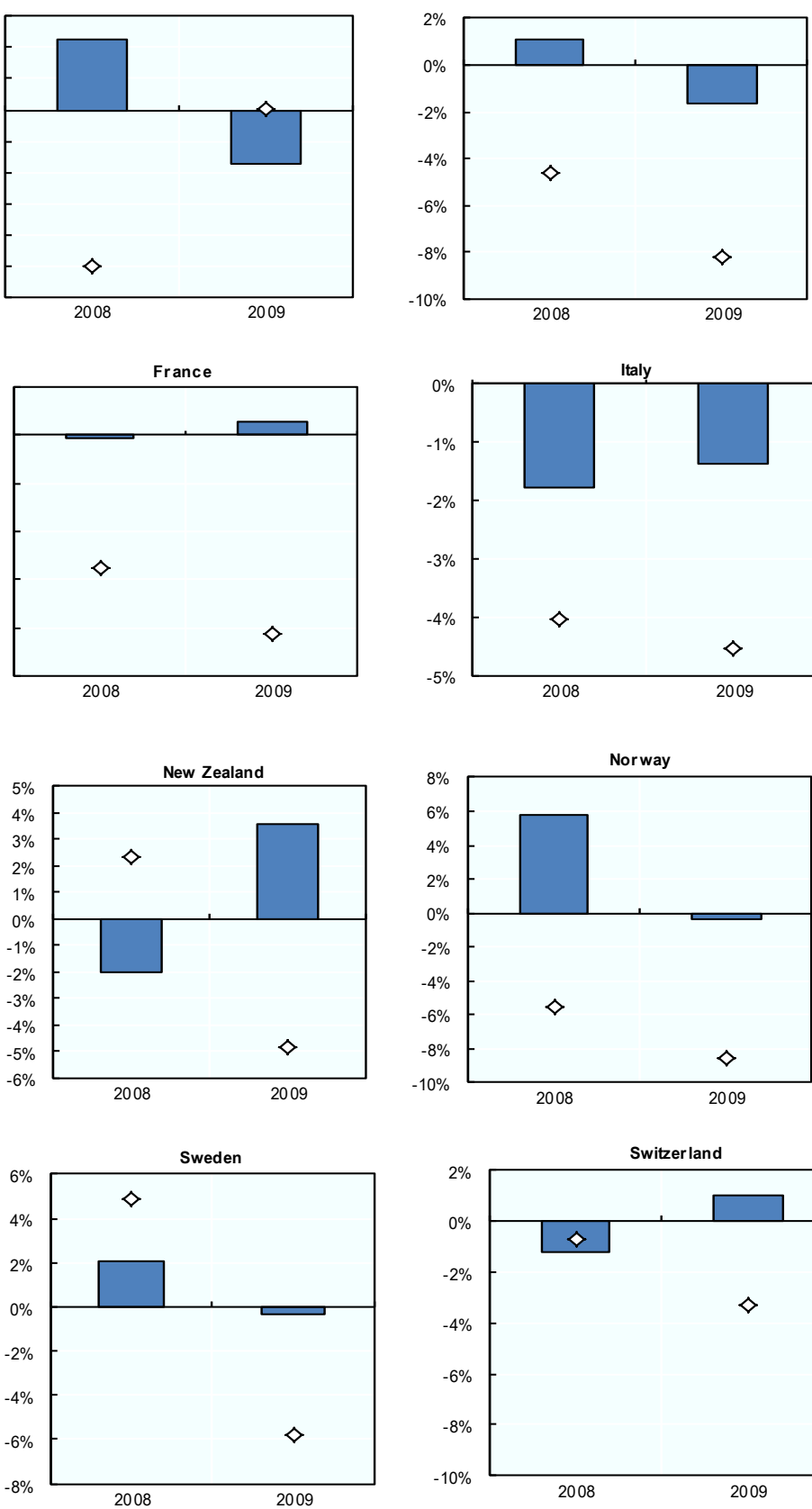

Norway

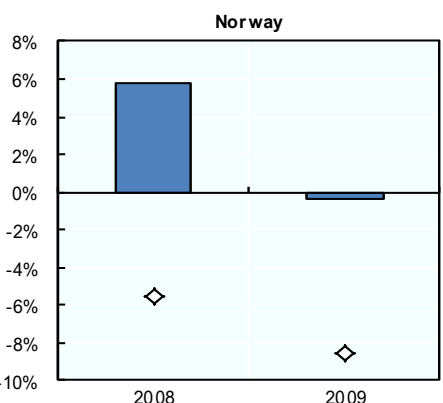

Switzer land

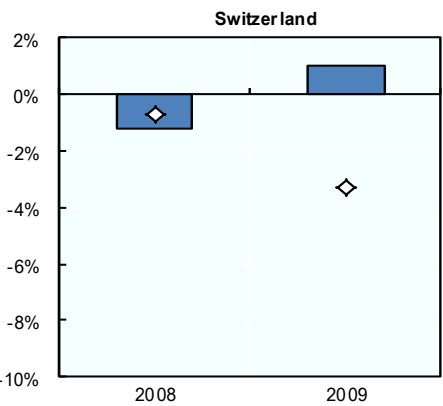

Denmark
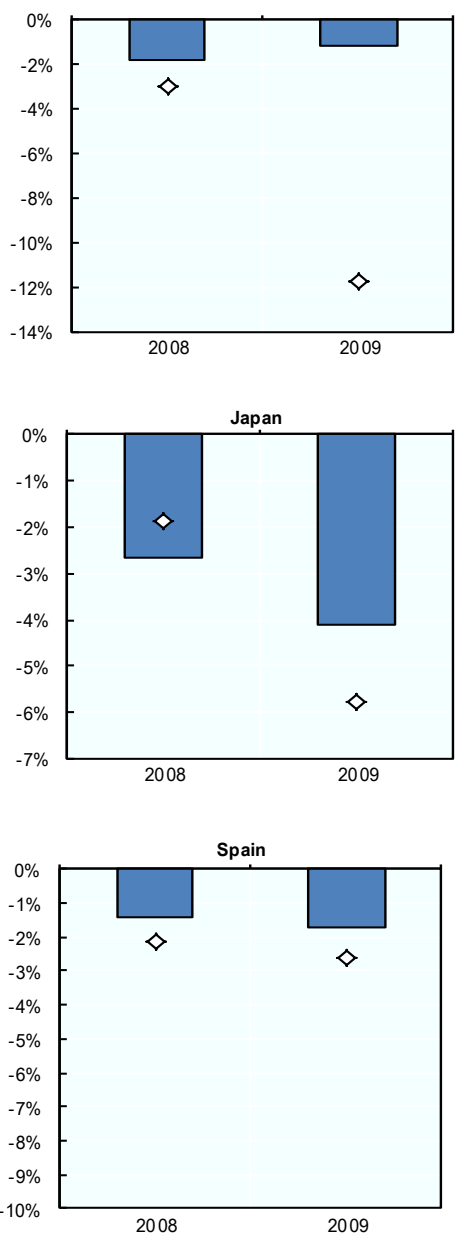

United States

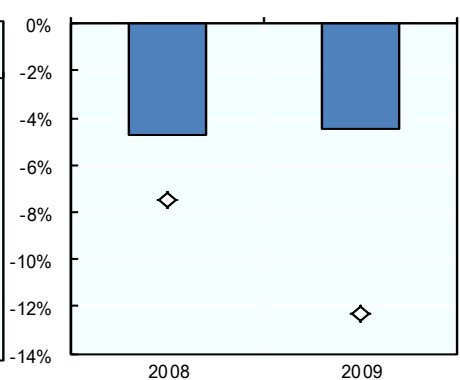

Source: World Top Incomes Database 
In 2009 the incomes of the top percentile fell by 8 to 9 points more than the for rest of the population in France, New Zealand, Norway and the United States, more than 10 points in Denmark, 6.6 points in Canada, and 5.5 points in Sweden. This does not mean that the crisis did not hit strongly the bulk of the population, which might have suffered higher welfare losses than the top $1 \%$ of earners, since they are more vulnerable to income shocks, especially in countries without strong safety net programmes. But the 2008 financial crisis temporarily put an end to growing top $1 \%$ income shares.

An important question is whether the crisis is likely to affect permanently the income distribution. The study by Roine, Vlachos and Waldenström (2009) using data for 16 countries over the $20^{\text {th }}$ century holds that a banking crisis is predicted to reduce permanently the share of income accruing to the top $1 \%$ by about 0.2 percentage points, on average. Atkinson and Morelli (2011), analysing the banking crises over the $20^{\text {th }}$ century, show that crises very often result in changing the direction of trends in inequality, but in either direction. Banking crises do not systematically translate into rising or declining inequality, even though in the majority of cases inequality increased after a crisis. But banking crises have no mechanical or clear-cut permanent effect on top incomes.

Figure 11 displays how the top $1 \%$ and top $0.01 \%$ income shares have evolved since 2007 . In all countries but Sweden the crisis impact on top income shares was noticeable in 2008: the 2008 crisis has put (temporarily) an end to the increase in the share of national income flowing to the top percentile and groups further up the income ladder. The crisis effect is larger for very high income earners than for those in the top percentile. In Japan, the crisis seems to have had no impact on the top percentile income share. But looking at the top $0.01 \%$, an effect (though relatively moderate) may be observed.

Figure 11. Top income shares since the crisis
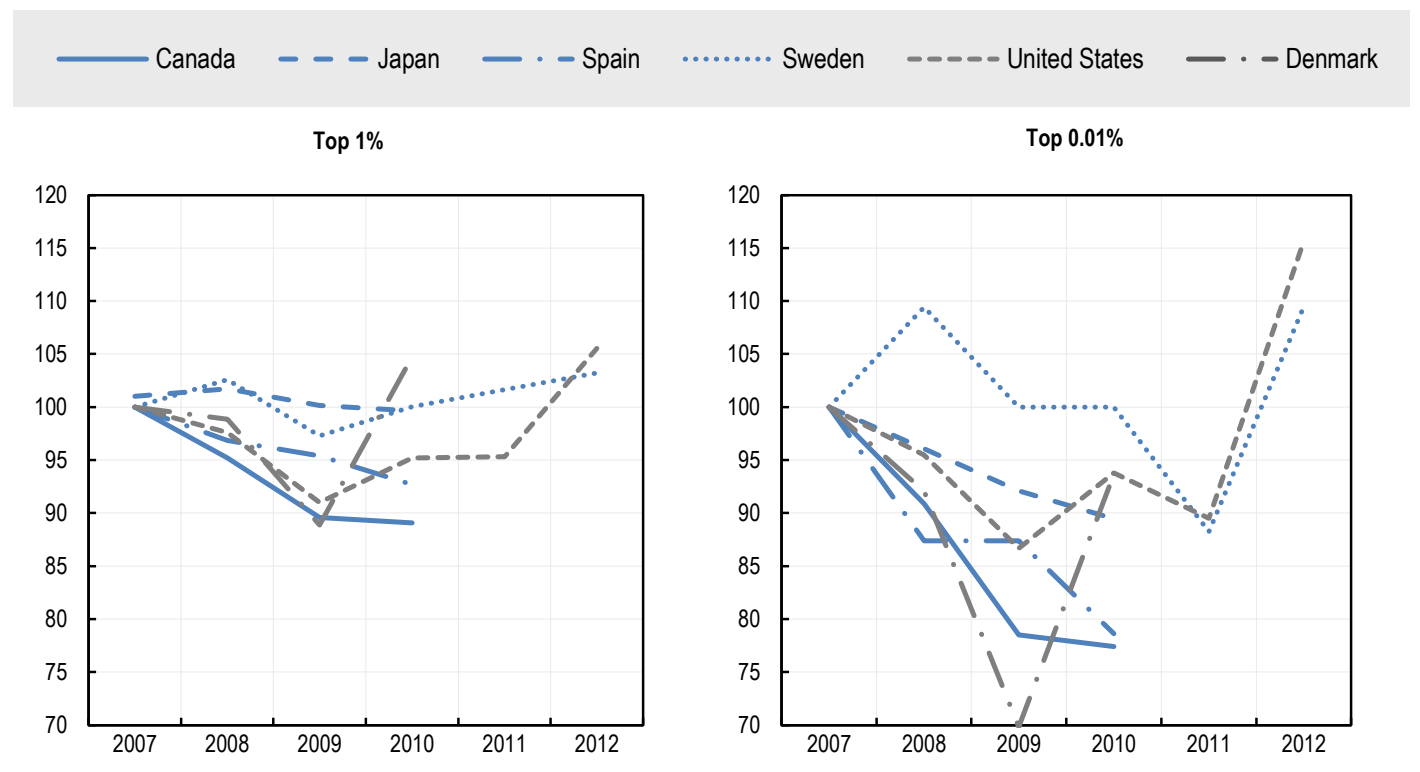

Source: World Top Incomes Database

Recovery seems, however, to have started in Denmark, Sweden and the United States ${ }^{5}$, as well as in Australia and Norway (no data on top $0.01 \%$ shares available in these two countries) ${ }^{2}$, while in Canada, Japan and Spain the top income shares were still declining in 2010. In the past, the 2000-2001 recession turned out to have no medium run impact on income concentration at the top. Top income shares recovered rapidly after the end of the 2001 crisis and had been rising strongly until the 2008 financial crisis (Saez, 2012). Though there is not enough hindsight yet to measure the long-term consequences of the crisis on income inequality, one may reasonably think that the crisis will not reverse the trend for increasing top income shares, unless new policies aiming at reducing inequality are implemented. Saez (2012) argues that economic downturns have no long-run impact on concentration of income unless regulation and tax policy are implemented, preventing income concentration from increasing again.

5 Part of the surge of top $1 \%$ incomes in the US in 2012 is likely to be due to income retiming to benefit from lower top tax rates in 2012 relative to 2013 (Saez 2013). 


\section{Top incomes and inequality}

28. The previous section has shown that the share of top incomes in total pre-tax incomes has increased significantly in a number of OECD countries. How has this affected overall income distribution? The effect will depend on how the average annual growth is distributed between the different fractions of the population. This section presents first which fraction of total annual income growth is "captured" by the top $1 \%$ and by the remaining fractions of the income distribution. Given the high volatility of top income shares illustrated in box 2, this part focuses on the 30-years period up to the crisis. In a second step, the section examines the relation between changes in top income shares and overall inequality as measured by the Gini coefficient.

\subsection{Income growth and top incomes}

29. Table 1 shows that between 1975 and 2007 the average income of the top $1 \%$ of earners has grown at a quicker pace than the average income of the rest of the population in all countries but Denmark and Portugal. Unsurprisingly, given the surge in top incomes in those countries, the difference in average annual growth between the top percentile and the rest of the population is much more pronounced in the English-speaking countries than in other OECD countries. In some countries, average income growth is driven up significantly by the top $1 \%$ income growth.

30. An alternative way to look at the issue is to calculate how much of the overall income growth over a given period has been "captured" by income groups at the top. ${ }^{6}$ Over the last thirty years a very large fraction of growth has been captured by the top percentile in English speaking countries, particularly in North America - around $47 \%$ of total growth has benefited the top 1\% in the United States, 37\% in Canada and around 23-24\% in Australia and the United Kingdom. Compared to these countries, the bottom 99\% of the population in Nordic countries but also in Portugal, Spain and France benefited more significantly from income growth, receiving about $90 \%$ of the total pre-tax income growth.

Table 1. Income growth and top percentile share from 1975 to 2007

\begin{tabular}{l|c|c|c|c}
\hline & $\begin{array}{c}\text { Average annual } \\
\text { real income growth }\end{array}$ & $\begin{array}{c}\text { Top 1\% annual } \\
\text { real income } \\
\text { growth }\end{array}$ & $\begin{array}{c}\text { Bottom 99\% } \\
\text { annual real } \\
\text { income growth }\end{array}$ & $\begin{array}{c}\text { Fraction of total } \\
\text { growth captured } \\
\text { by top 1\% }\end{array}$ \\
\hline Australia & $1.1 \%$ & $3.5 \%$ & $0.9 \%$ & $22.5 \%$ \\
Canada & $0.7 \%$ & $2.5 \%$ & $0.5 \%$ & $37.3 \%$ \\
Denmark & $0.7 \%$ & $0.4 \%$ & $0.7 \%$ & $2.5 \%$ \\
France & $0.8 \%$ & $1.1 \%$ & $0.8 \%$ & $11.4 \%$ \\
Italy & $1.5 \%$ & $2.2 \%$ & $1.4 \%$ & $11.5 \%$ \\
New Zealand & $0.8 \%$ & $2.3 \%$ & $0.8 \%$ & $14.3 \%$ \\
Norway & $2.4 \%$ & $5.6 \%$ & $2.3 \%$ & $11.7 \%$ \\
Portugal & $1.5 \%$ & $1.2 \%$ & $1.5 \%$ & $7.5 \%$ \\
Spain & $2.0 \%$ & $2.4 \%$ & $1.9 \%$ & $10.1 \%$ \\
Sweden & $1.6 \%$ & $2.5 \%$ & $1.5 \%$ & $8.8 \%$ \\
United Kingdom & $1.9 \%$ & $4.5 \%$ & $1.6 \%$ & $24.3 \%$ \\
United States & $1.0 \%$ & $3.9 \%$ & $0.6 \%$ & $46.9 \%$ \\
\hline
\end{tabular}

Note: France 1976-2005; Portugal: 1976-2005, New Zealand: 1976-2007, Italy: 1975-2005. Incomes refer to pre-tax incomes.

Source: World Top Incomes Database 
31. As highlighted by Atkinson et al. (2011), the surge in top incomes can have an impact on measured and perceived real income growth. In the United States, average income grew at an annual rate of $1 \%$ over the 30 years period. However, when excluding the top percentile, the annual growth rate falls to only $0.6 \%$. This helps understand why the official growth rate does not quite match the experience of most people whose incomes grew by much less than the average income growth. Excluding the top percentile may change considerably the country ranking in terms of annual income growth. For instance, average real income growth is lower in France than in the US over the period, but the picture is reversed when looking only at the bottom $99 \%$.

Figure 12. Share of income growth captured by income groups from 1975 to 2007

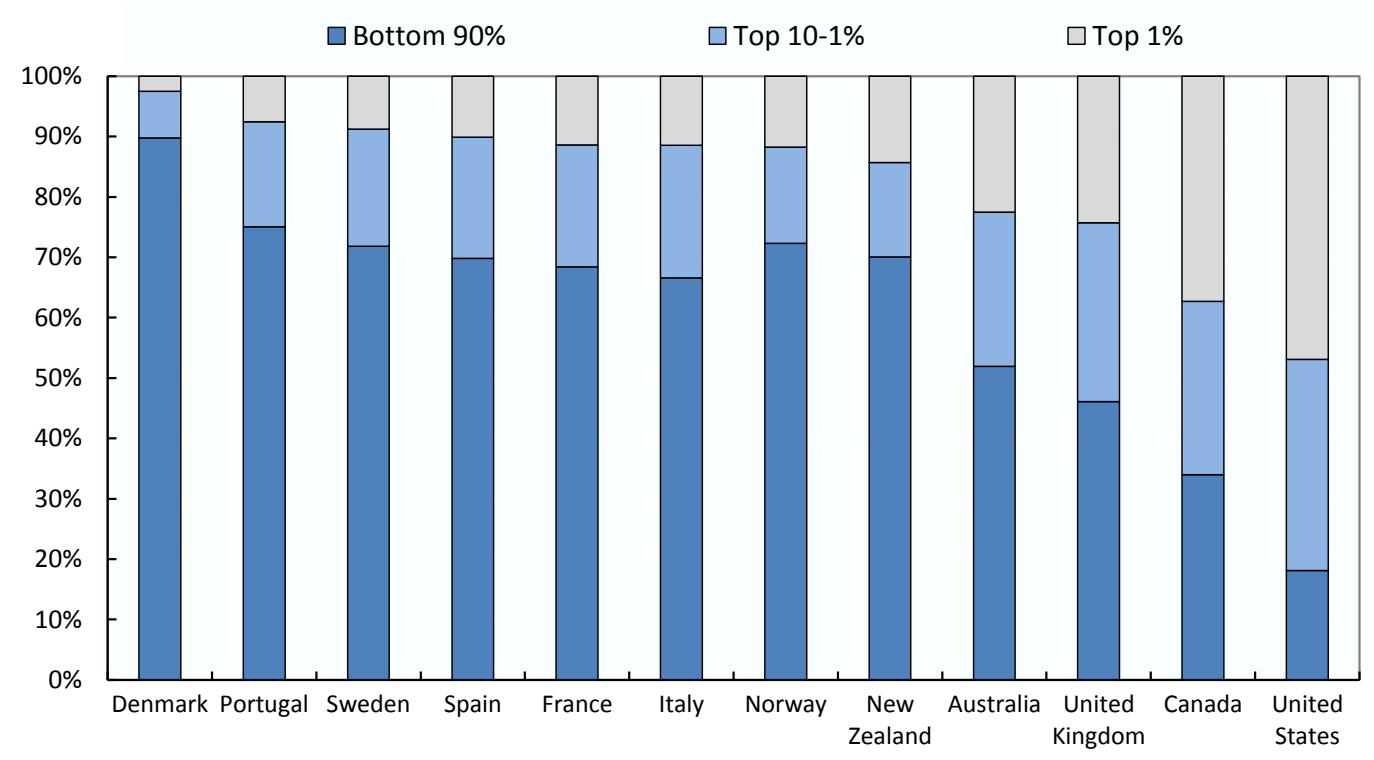

Note: Portugal: 1976-2005, New Zealand: 1976-2007, Italy: 1975-2005. Incomes refer to pre-tax incomes.

Source: World top incomes Database

32. The remaining $99 \%$ is not a homogenous group and hides a wide disparity. Figure 12 splits the "bottom 99\%" group into two subgroups, the upper-middle class (top 10-1\%) and the rest of the population (the bottom 90\%). About $80 \%$ of total income growth has been captured by the top decile in the United States, and around 65\% in Canada. In Australia and the United Kingdom, the bottom $90 \%$ benefited from more or less half of the income growth over the 30 year period. Income growth was shared more equally in other OECD countries for which data are available, albeit the top of the distribution benefited from growth proportionally more than the rest of the population.

33. Breaking down the top percentile into several sub-groups may help paint a more complete picture, since the fruits of growth may also not have been equally distributed within the top percentile. Unfortunately, data are available only for a limited number of countries. 
DELSA/ELSA/WD/SEM(2014)5

Table 2. Top percentile growth and income concentration between 1976 and 2007

\begin{tabular}{l|cccc|ccc}
\hline & \multicolumn{4}{|c|}{ real annual income growth of } & \multicolumn{3}{c}{ Fraction of top 1\% growth } \\
& \multicolumn{1}{|c}{ captured by } \\
\cline { 2 - 8 } & Top 1\% & $\begin{array}{c}\text { Top 1- } \\
0.1 \%\end{array}$ & $\begin{array}{c}\text { Top 0.1- } \\
0.01 \%\end{array}$ & $\begin{array}{c}\text { Top } \\
0.01 \%\end{array}$ & $\begin{array}{c}\text { Top 1- } \\
0.1 \%\end{array}$ & $\begin{array}{c}\text { Top 0.1- } \\
0.01 \%\end{array}$ & $\begin{array}{c}\text { Top } \\
0.01 \%\end{array}$ \\
\hline Canada & $2.4 \%$ & $1.5 \%$ & $3.8 \%$ & $7.0 \%$ & $46.2 \%$ & $31.1 \%$ & $22.6 \%$ \\
France & $1.0 \%$ & $0.7 \%$ & $1.4 \%$ & $2.4 \%$ & $55.4 \%$ & $27.1 \%$ & $17.5 \%$ \\
Sweden & $2.5 \%$ & $2.0 \%$ & $3.7 \%$ & $6.6 \%$ & $54.8 \%$ & $25.2 \%$ & $20.0 \%$ \\
US & $3.9 \%$ & $2.8 \%$ & $5.2 \%$ & $7.9 \%$ & $46.0 \%$ & $29.3 \%$ & $24.7 \%$ \\
\hline
\end{tabular}

Note: Incomes refer to pre-tax incomes.

Source: World top incomes Database

34. Table 2 displays the annual average income growth for subgroups within the top percentile. In all four countries, real income grew at a faster pace for higher income groups, even in France where the top income growth was limited. Unsurprisingly, in Canada and the United States top 0.01\% exhibit very high growth rates, but this is also the case for Sweden. Top $0.01 \%$ average income explains by and large $25 \%$ of the growth in top $1 \%$ average income in Northern American countries, slightly less in Sweden and in France. In all four countries, the richest are benefiting disproportionally more from income growth than the rest of the top percentile, meaning that concentration of income is happening also within the top percentile. The distribution of income growth within the top percentile roughly follows the same pattern in all four countries, despite the fact that the fraction of total growth captured by the top 1 percent differs widely from one country to another. As a result, given the larger fraction of income growth was captured by the top $1 \%$ of earners in Canada and the United States than in Sweden and France, the share of total growth going to the top $0.01 \%$ differ ranges from less than two percent in France and Sweden to almost 12 percent in the United States (See Annex A2 for a more detailed figure).

\subsection{Top incomes and overall pre-tax inequality}

35. An important issue is to identify how top income shares relate to overall income inequality. Top income shares measure the concentration of pre-tax income at the top of the distribution. Therefore, they do not provide any information on the shape of the middle and the bottom of the income distribution. The share of income accruing to high earners is obviously not the only factor driving the dispersion of earnings and incomes across the population. Income inequality is also strongly related to the income distribution among the rest of the population and, in particular, developments at the lower tail of the income distribution. 


\section{Box 3. Top incomes share and the axiomatic approach to inequality measurement}

As stated by Leigh (2009), a way to look at whether top income shares are a good inequality measure is to turn to theory. Cowell (1995) brings out five axioms that inequality measures should satisfy. Anonymity (or symmetry) entails that the inequality metric be not affected by other characteristics than income. All that matters is the distribution of income, not the characteristics of the individuals. Income scale independence requires the inequality measure to be independent from the aggregate level of income, meaning that multiplying everyone's income by a constant should not change the inequality measure. Similarly, the principle of population (or homogeneity) states that the inequality measure has to be independent from the size of the population. The inequality measure should be the same for any replication of the population. The weak principle of transfer implies that an income transfer from a rich person to a poor person should reduce inequality. Decomposability requires that increasing inequality in a given subgroup should result into increasing overall inequality. Overall inequality should be broken down in within-group inequality and betweengroup inequality.

Do top income shares satisfy those axioms? It is straightforward to see that, by construction they satisfy the first three principles (anonymity, income scale independence, and the principle of population). If the aggregate income is multiplied by a constant it obviously means that both the numerator (income accruing to top earners) and the denominator (total income) are multiplied by the same constant which consequently cancels out. The same holds if the population is replicated. As top income shares focus only on the income distribution, the anonymity principle is therefore satisfied.

However, top income shares satisfy only partly the weak principle of transfer. While a transfer from a high earner to a poor person will reduce (or at least not increase) the top income share, a transfer between two individuals belonging to the top income group or two individuals outside this group has no effect on the top income share. Further, top income shares may not be decomposed into within-group inequality and between-group inequality, since they are measuring the fraction of income accruing to one specific group.

Top income shares do not satisfy all the desirable properties of a "perfect" inequality measure. However, neither does the most commonly used inequality measure, the Gini coefficient. As theory does not provide clear-cut conclusions about the pertinence of using top income shares as an inequality measure it is useful to examine the empirical correlation between top income shares and other inequality measures.

36. Figure 13 plots the share of pre-tax income accruing to the top percentile and the Gini coefficient of income concentration in those OECD countries where both information is available, in the late $2000 \mathrm{~s}^{7}$. In order to look at roughly comparable income concepts, the Gini coefficient corresponds to incomes before taxes and transfers, rather than the common measure which refers to disposable (post tax) incomes. The Gini coefficient is commonly used to measure income inequality and takes into account the whole income distribution (though being over-sensitive to the middle of the distribution). The two inequality measures seems to be only loosely related, albeit positively. ${ }^{8}$ Some countries, as France and the United States display similar pre-tax Gini coefficients but very different shares of the top 1 percent income. Likewise, the share of income flowing to the top $1 \%$ of earners is similar in Norway and Portugal while the Gini coefficient is nine points higher in Portugal than in Norway. Italy, Japan and Portugal have some of the highest pre-tax and transfer Gini coefficients among OECD countries but the top percentile shares are relatively small compared to the United States or the United Kingdom. The two measures provide different country rankings in term of inequality.

7. It should, however, be kept in mind that the two measures are calculated using different data sources. The top income shares are derived from tax returns while the Gini coefficients are computed using household survey data. However, in contrast to most countries where data from tax returns are available only for a fraction of the population, income tax data in Denmark offer a full coverage of the Danish population. Atkinson and Sorgaard (2013) use Danish income tax data to compute the Gini coefficient and top income shares and show that the development in the Gini coefficient follows closely that of the top $10 \%$ income shares in Denmark.

8. The correlation coefficient is 0.42 
Figure 13. Top percentile income shares and pre-tax Gini coefficients in the late 2000s

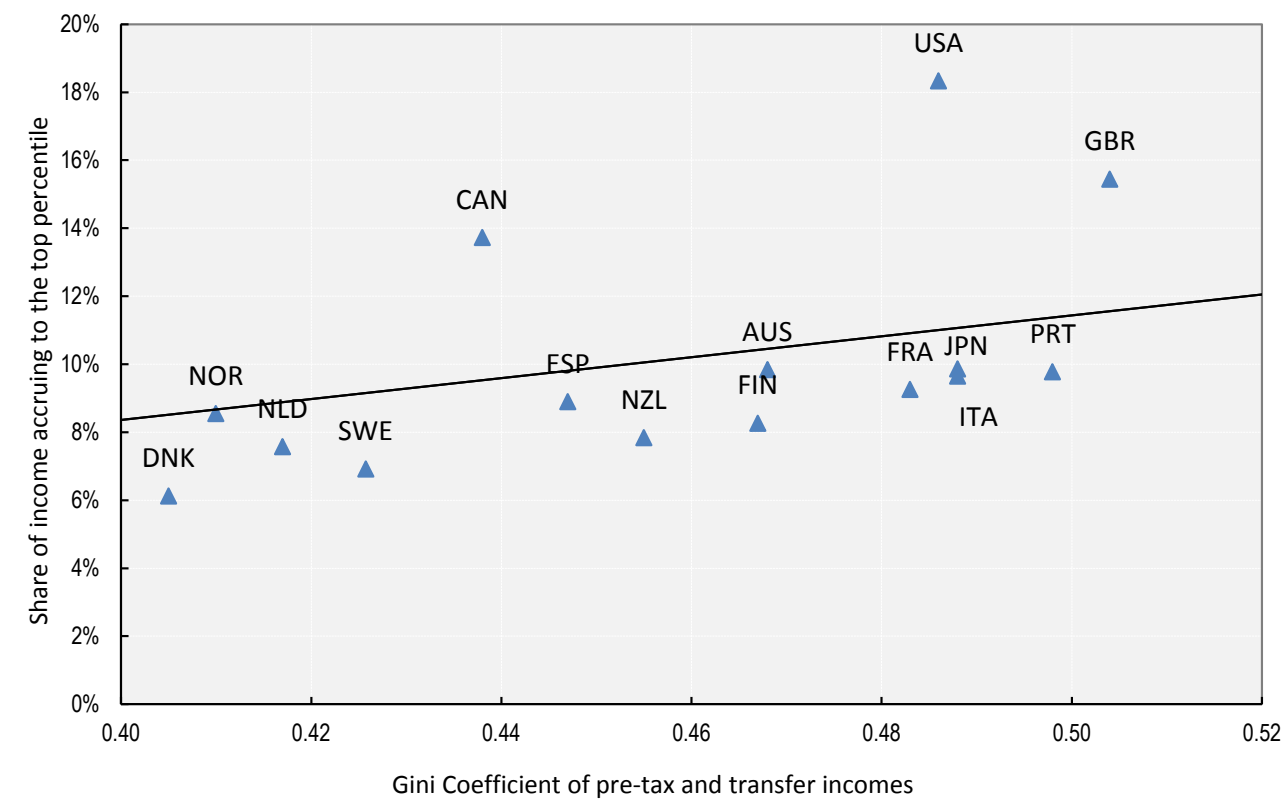

Source: World Top Income Database for top 1\% pre-tax income share, OECD Income Distribution Database for pre-tax Gini coefficient.

37. Even though the data used for computing the two measures are not fully comparable, there may be other reasons for such differences. First, the surveys which underlie the calculations of the Gini coefficient typically tend to under-sample high earners ${ }^{9}$ (Moore, Stinson and Welniak 2000). Second, even if the share of income flowing to the top $1 \%$ of earners remained constant, a higher concentration of the remaining 99\% around the median income would lower the Gini index. Third, by construction, the Gini coefficient is more sensitive to income transfers at the middle than at the tails of the distribution -because it indicates the spread of the income distribution or deviation from the mean - while top income shares do not tell anything about the middle and the bottom of the income distribution. Although the two indexes are only partially overlapping in term of what is measured, their trends are positively associated (see Leigh 2007 for an in-depth analysis), suggesting that the same factors affect both the top of the other parts of the income distribution. ${ }^{10}$ However, the impact of top income shares on disposable income inequality is far from being mechanical, since the tax and transfer system typically reduces income disparity significantly. As the redistributive impact of the tax system can change over time, changes in the top income shares do not systematically reflect changes in overall inequality in terms of disposable income. ${ }^{11}$

9. A random sample of the population is selected for household surveys but this may differ from the final sample used if not all intended households are interviewed. High-income earners may be difficult to contact and to be persuaded to participate, making the results more biased towards the lower income groups. While estimation weights may be used to correct for sampling error, they can correct estimates of totals but might not be sufficiently accurate for this particular group In addition, item non-response for income tends to be high in household surveys and this can be higher for particular income sources. Data accuracy may suffer from recall issues, misreporting or unwillingness to provide full information because they respondents may also be uncomfortable discussing income overtly.

10. These factors are reviewed in section 4 .

11. The econometric analysis from Leight (2007) of the relation between top income shares and inequality measures is based on disposable income for the latter. 
38. Alvaredo (2010) gives a general formula of the relationship between top income shares and the Gini coefficient. As survey data suffer from under-reporting at the top, his proposal is to improve the Gini coefficient computed using survey data by incorporating top incomes share estimates coming from tax data. Taking the case of the United States, he computes the Gini coefficient for the bottom $99 \%$ of the population using CPS data and then corrects this estimate using the top 1\% share from tax data. Results are summarised in the table below.

Table 3. Top income shares and the pre-tax Gini coefficient in the United States, 1976 and 2006

\begin{tabular}{|c|c|c|c|c|}
\hline & $\begin{array}{c}\text { Gini } \\
\text { coefficient - } \\
\text { CPS data }\end{array}$ & $\begin{array}{c}\text { Gini } \\
\text { Coefficient - } \\
\text { bottom } 99 \%\end{array}$ & $\begin{array}{c}\text { Gini coefficient } \\
\text { corrected with } \\
\text { tax-based top } 1 \% \\
\text { (excluding capital } \\
\text { gains) }\end{array}$ & $\begin{array}{l}\text { Gini coefficient } \\
\text { corrected with } \\
\text { tax-based top } 1 \% \\
\text { (including capital } \\
\text { gains) }\end{array}$ \\
\hline$\overline{1976}$ & 0.503 & 0.482 & 0.509 & 0.514 \\
\hline 2006 & 0.588 & 0.540 & 0.609 & 0.632 \\
\hline Point increase & 0.085 & 0.058 & 0.100 & 0.118 \\
\hline $\begin{array}{l}\text { Point increase } \\
\text { removing the } 92- \\
93 \text { CPS } \\
\text { discontinuity }\end{array}$ & 0.062 & 0.058 & & \\
\hline
\end{tabular}

Note: Incomes refer to pre-tax incomes.

Source: F. Alvaredo (2010)

39. The "corrected" Gini (including capital gains) is higher than the officially reported Gini by about 1 percentage point in 1976 but 4 percentage points in 2006. The Gini coefficient computed using only survey data, which does not measure top incomes properly, therefore underestimates the increase in overall inequality that took place over the last three decades. With an increase of almost 12 points, the increase in the Gini coefficient corrected with the tax based top $1 \%$ income share (including capital gains) is almost twice as large as the 6.2 percentage points increase recorded using the CPS data only. This confirms that top incomes play an important role in driving the increase in overall inequality in the United States. Ignoring top incomes on the pretext that they are only a small fraction of the income distribution may lead to underplaying the magnitude of the changes in overall inequality.

\section{Characteristics of top earners}

40. This section looks at three different aspects of characterising top earners. It first presents the composition of income for top income earners in various OECD countries and compares its evolution over time. The section then discusses in which occupations top incomes are primarily found and whether there is substantial stability in the composition of top incomes or not. Unfortunately, information on these characteristics is available only for a handful of OECD countries.

\subsection{Income components of top earners}

41. While the market income of the bulk of the population is mostly from labour, high earners tend to have multiple sources of income. Figure 14 shows the income composition of four income groups for five OECD countries where this information is available. Considerable care is needed when comparing the income composition of top income groups across countries, since the labelling of income strongly depends 
on country-specific factors. While distinguishing labour from capital income is not difficult, the distinction between capital income and business income on the one hand, and between wages and business income on the other may turn out to be difficult as the labelling of income may be affected by national corporate law and tax legislation.

42. In all countries but Canada, the further up on the income ladder, the smaller the share of wage income. The largest part of the upper middle class' income (the top 10-1\%) comes from wages and pensions, ranging from $70 \%$ in Italy to more than $85 \%$ in Canada. In this respect, this income group is more similar to the bottom $90 \%$ than to the top percentile. In figure 14, the top percentile is broken down into three sub-groups. In all five countries the share of capital income is the largest for the top $0.01 \%$ but there is considerable cross-country variation in the size of this share, ranging from about $20 \%$ in Canada up to almost $60 \%$ in France.

43. In Italy, business income represents around $45 \%$ of the total income of the top $0.1 \%-0.01 \%$ and top $0.01 \%$, suggesting that a large share of top earners in Italy are business owners. In Canada, wage income constitutes the bulk of top earners' income, even at the very top of the distribution, as more $70 \%$ of the income of the top $0.01 \%$ is made up of wages and pension, suggesting that in Canada a substantial fraction of top earners are very well-paid executives. The picture looks very different in France where less than $30 \%$ of the top $0.01 \%$ 's income is made up of wages while next to $60 \%$ stems from capital income. Regarding top incomes composition, Spain and the United States look fairly similar, with a declining share of wage income while going further up on the income ladder.

44. Over the last decades, income composition of top earners evolved differently across countries. The most striking changes took place at the very top of the distribution (typically the top $0.1-0.01 \%$ and top $0.01 \%$ ) Decomposing the income into its different components may help understand what is driving the top incomes growth that has been occurring over the last three decades in a number of OECD countries. An increase in the share of a given income component, say wages, may be due to the increasing number of individuals within the top percentile deriving most of their income from wages but also to rising wages of taxpayers belonging to the top percentile. The two factors may obviously happen simultaneously, and are hard to disentangle. 
Figure 14. Income composition of top income groups in the late 2000 s

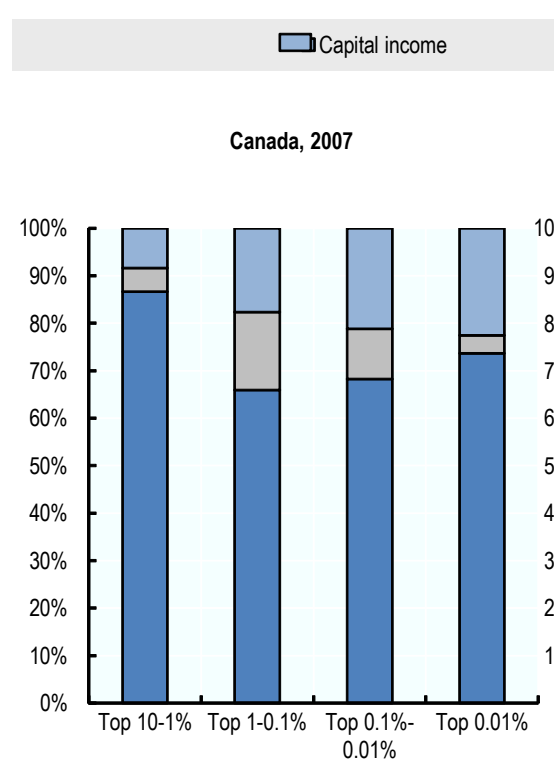
$\square$ Business income
$\square$ Salaries

France, 2005

Italy, 2007
United States, 2007

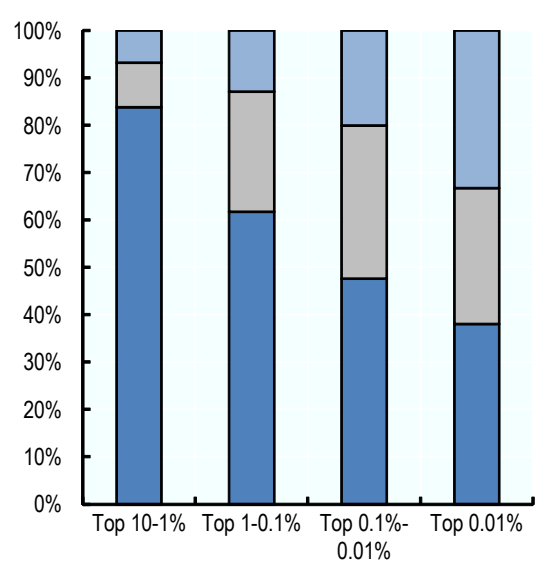

Spain, 2007

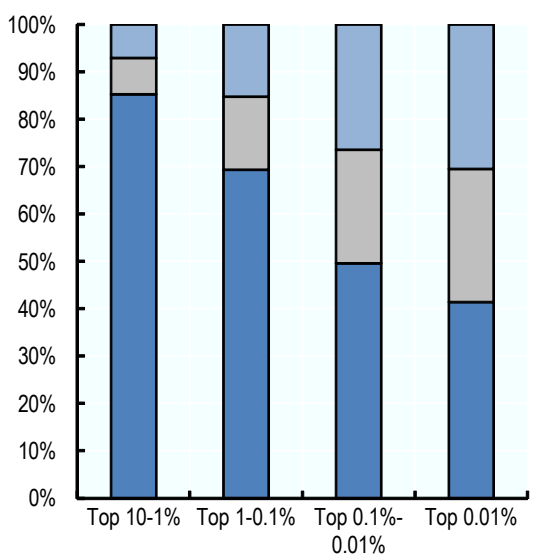

Note: Business income includes self-employment income, partnership income and income derived from closely-held businesses. Incomes refer to pre-tax incomes.

Source: WTID

45. Is the increase in top income shares observed in recent decades in some OECD countries related to a change in the income composition of top earners? Figure 15 presents the top $0.1 \%$ income share and composition in four OECD countries from the early 1970s to the late 2000s. First, the figure shows that the share of gross income accruing to the top $0.1 \%$ rose dramatically in Canada and the United States countries from the early 1970 to the late 2000 s and a less marked but steady increase in Italy. The top $0.1 \%$ share in France does not show a clear upward trend over the entire period. However, from 1996 to 2005 the top $0.1 \%$ income share has gone up by more than 25\%. Second, Saez and Veall (2005) argue that that increasing income shares are primarily due to the rise in the pay of highly paid executives (which may stem from stock-options' development). The data confirm an increase in the share of wages and business income out of total income of high earners in Canada and the United States (but only until the early 2000s 
for the US), suggesting that labour compensation has played a key role in income growth at the top of the distribution. Similarly, In Italy, the growing shares of both business income and wages seem to be behind the steady increase in top $0.1 \%$ income share. At the same time, the increase in France seems to have been driven by both growing wages and capital income. Furthermore, in the more recent years (since the early 2000s), most of the growth in top income shares in the United States may be put down to a rising capital income share.

Figure 15. Top $0.1 \%$ income share and income composition in recent decades

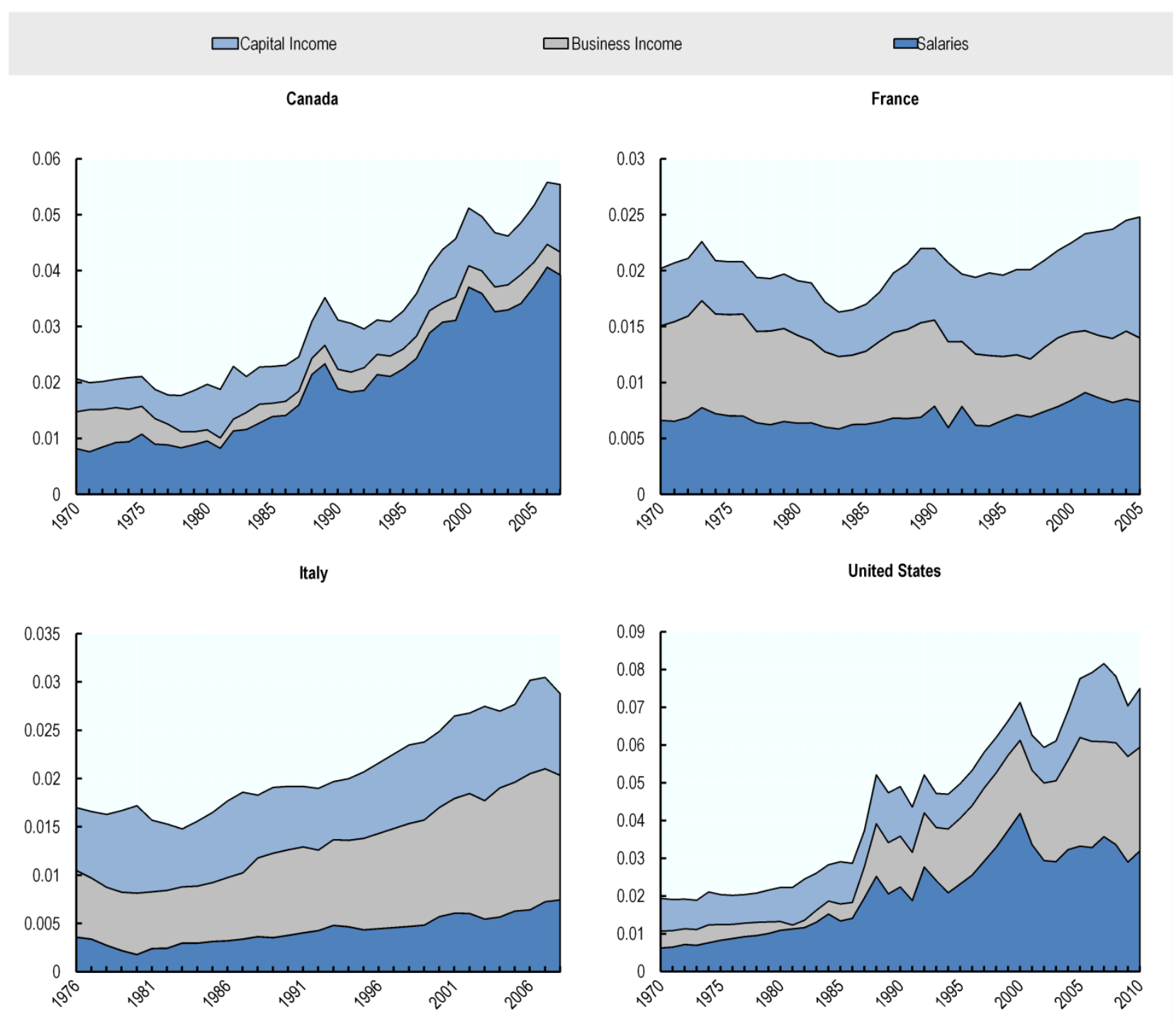

Note: Incomes refer to pre-tax incomes.

Source: World Top Incomes Database

46. In summary, the surge in the top income shares over the recent decades seems related to increasing labour compensation, except in the United States where the top 0.1\% income share over the last decade was driven mostly by growing capital and business income. But it must be kept in mind that in some countries capital income may be underreported, as some types of capital income are not subject to the income tax and consequently not reported in the tax files. 


\subsection{Top earners' occupations}

47. Bakija, Cole and Heim (2012) present statistics on the occupations of taxpayers in the top percentile of the national income distribution in the United States. Note that not all the individual income may come from the declared occupation, but may stem also, for instance, from capital income. Table 4 shows that executives, managers, medical and financial professionals make a large part of the top percentile, and even more so when looking at the top $0.1 \%{ }^{12}$. The major change in occupations of top earners between 1979 and 2005 is the rising share of financial professionals, from 8 to 14\%. There are also more real estate professionals in the top $1 \%$ group in 2005 than in 1979, but they make up only a small overall fraction of the top percentile.

Table 4. Occupation of taxpayers in the top percentile in the United States

\begin{tabular}{l|c|c}
\hline & 1979 & 2005 \\
\hline $\begin{array}{l}\text { Executives, managers, } \\
\text { supervisors (non-finance) }\end{array}$ & $36.0 \%$ & $31.0 \%$ \\
Medical & $16.8 \%$ & $15.7 \%$ \\
$\begin{array}{l}\text { Financial professions, } \\
\text { including management }\end{array}$ & $7.7 \%$ & $13.9 \%$ \\
$\begin{array}{l}\text { Lawyers } \\
\text { Computer, math, } \\
\text { engineering }\end{array}$ & $7.0 \%$ & $8.4 \%$ \\
Real estate & $3.8 \%$ & $4.6 \%$ \\
Other & $1.9 \%$ & $3.2 \%$ \\
\hline
\end{tabular}

Source: Bakija, Cole and Heim (2012)

48. According to the authors' calculation, executives, managers and financial professionals captured $60 \%$ of the increase in the top $1 \%$ share from 1979 to 2005 ( $70 \%$ of the top $0.1 \%$ share's). This results from the rate of income growth between 1979 and 2005 differing widely across occupations within the top incomes groups ${ }^{13}$. Real estate and financial professionals within the top $0.1 \%$ group experienced higher annual income growth (around 6\%) than people in other occupations (such as lawyers or medical professionals), leading to a growing divergence of average incomes across professions among the top $0.1 \%$. Unfortunately, no evidence on occupations of top income earners is available for other countries.

\subsection{Income Mobility}

49. Mobility in and out of top income groups is a crucial issue as income inequality would be somewhat less of a concern if there were significant potential for people to move up the income ladder.

\footnotetext{
12. See Annex A3.

13. The authors examine how the mean real income in each occupation in a given income group would have evolved over the period, had the occupational composition in top quartiles remained the same. By doing so, they control for the composition effect that could otherwise bias the results.
} 
Income mobility may occur within the individual life or between generations. If there was perfect income mobility, everyone would eventually benefit from high income over their life cycles.

\section{Individual mobility}

50. As underlined by OECD (2011a), there are several factors, such as life-cycle effects on employment outcomes and fluctuations of financial markets that may partly explain income inequality and leave room for natural income mobility ${ }^{14}$. A significant amount of mobility may be related to age effects: earnings typically follow an inverted U-shaped curve, rising as work and career develops, then falling at retirement. Illnesses and periods out of the labour market also impact on life-cycle reasons for mobility. Regarding the impact of age, Solard (2004) shows that the average age of the household head in France is 50 years in the $90 \%$ poorer households, and 53.5/55.3 years in households belonging respectively to the top $1-0.1 \%$ and to the top $0.01 \%$. However, income concentration at the top of the distribution is likely not to be driven solely by life-cycle effects.

51. Looking at exit rates of top income groups is another way to measure individual income mobility. Table 5 displays the exit rate of the top percentile between 2006 and 2007. Mobility out of the top 1\% is significantly higher in Australia and Norway than in Canada and the United States. Mobility is higher for individuals belonging to the top $0.01 \%$ in all countries data are available for, suggesting that incomes of very top groups are more likely to fluctuate, partly related to the fact that a higher fraction of their income is derived from business and capital incomes. Annual turnover for the top 0.01\% is lower in France than in Australia and the United States. This variation may partly be explained by differences in the income composition of top earners. Capital income accounts for about $60 \%$ of the top $0.01 \%$ total income in France, compared with one third only in the United States. Exit rates of top groups should be higher if capital gains were to be included in the definition of total income as there is higher volatility in capital gains income.

Table 5. Exit rate of the top groups in 2007

\begin{tabular}{l|ccccc} 
& Australia & Canada & France & Norway & $\begin{array}{c}\text { United } \\
\text { States }\end{array}$ \\
\hline Top $1 \%$ & $37.0 \%$ & $28.9 \%$ & $30.0 \%$ & $36.3 \%$ & $26.4 \%$ \\
Top $0.01 \%$ & $67.0 \%$ & $\ldots$ & $44.0 \%$ & $\ldots$ & $71.0 \%$ \\
\hline
\end{tabular}

Top 1\% of household for France.

Source: Australia, Canada, Norway and United States: OECD (2011a); France: Solard (2008)

52. Somewhat surprisingly, given the trend increase in income shares of top earners, exit rates remained rather stable over the past 15 years. Figure 16 shows that, although mobility out of the top percentile seems to have increased slightly in Norway (except for a peak in 2006) and the United States, there is no clear trend visible over the past 15 years.

14. One extreme case would be that of a pure life-cycle model, in which all income inequality is due to differences in age. 
Figure 16. Exit rate from the top percentile over time

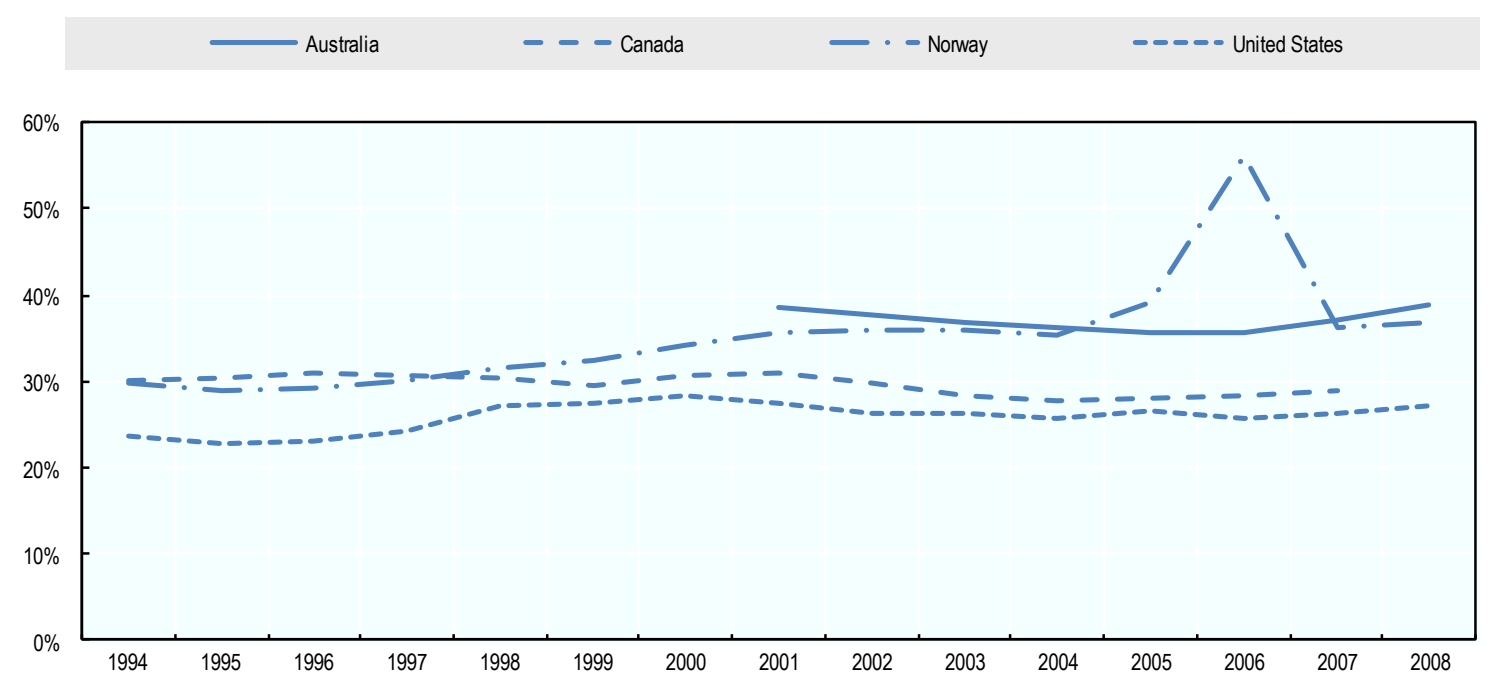

Source: OECD (2011a)

53. Few studies look at income mobility in and out of top income groups, primarily because highquality longitudinal datasets are rare and typically difficult to access. Saez and Veal (2004) use a Canadian longitudinal administrative dataset of individual tax returns to analyse mobility at the top. The probability of staying in the top $0.1 \%$ group is around $60 \%$ one year later, $50 \%$ two years later and about $40 \%$ three years later. They find that mobility does not vary much between the early 1980s and 2000. Using data from panels of individual tax returns, Auten and Gee (2009) show that there was a more substantial overall income mobility in the United States over the 1987-1996 and 1996-2005 periods, with half of the taxpayers moving to another income quintile within the period. Mobility was also substantial for the top of distribution with a large change in the composition of the top income groups. The percentage of individuals remaining in the top quintile is $87 \%$, while it is around $41 \%$ for the individuals in the top percentile. ${ }^{15}$ Mobility within the top percentile is even larger. However, they find no change occurred in mobility at the top when comparing the 1987-1996 and 1996-2005 periods.

\section{Intergenerational mobility}

54. Analysing intergenerational mobility at the top of the income distribution is crucial for evaluating the recent increase in income inequality. The social acceptance of rising income concentration at the top is often deemed to depend chiefly on the reasons why those at the top of the income distribution got there. Economic success based on personal merit is usually more tolerated than wealth derived from inheritance (Fong 2001). Few studies examine intergenerational income mobility at the top of the income distribution. Using a large dataset of matched father-son pairs, Björklund, Roine and Waldenstöm (2012) investigate intergenerational income mobility in Sweden and find that intergenerational transmission is very strong at the extreme top of the distribution (Figure 17).

15. However, this does not necessarily imply that those individuals remained in the top $1 \%$ for 9 consecutive years. 
Figure 17. Income transmission across the distribution in Sweden

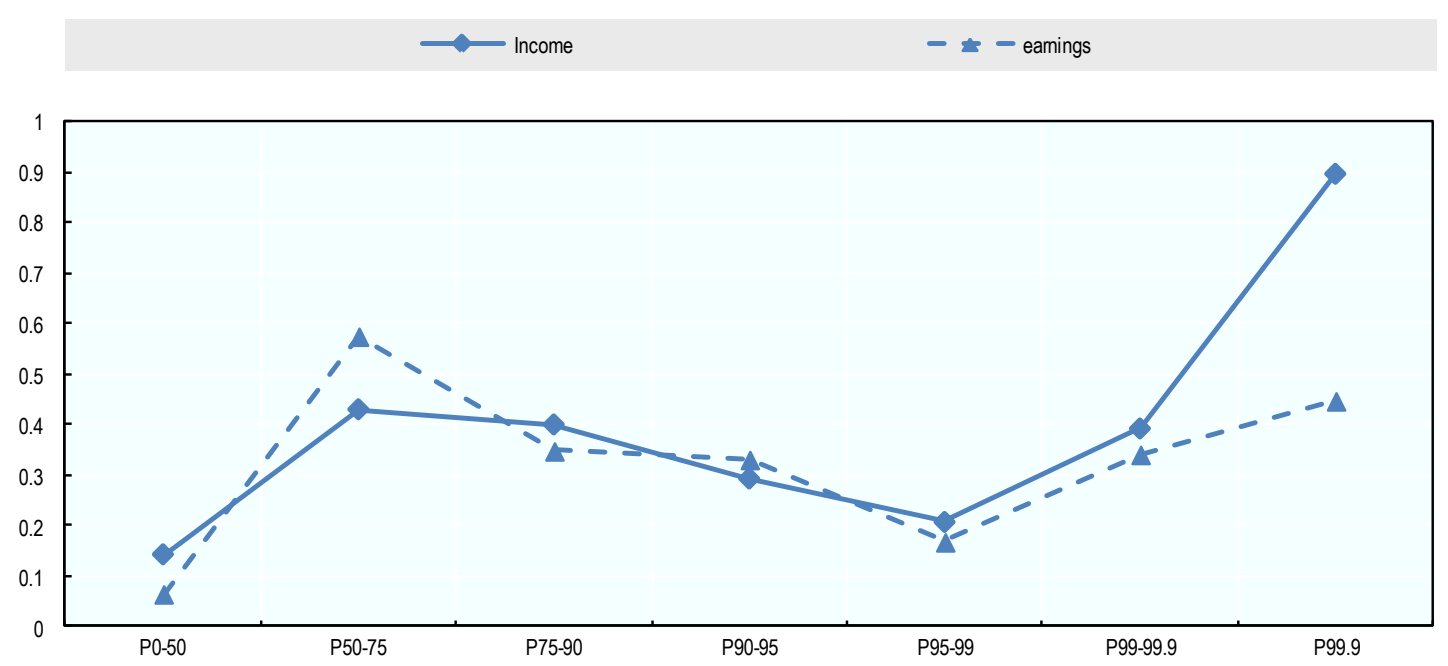

Note: The lines represent the coefficient of linear spline regressions is presented above. It measures the elasticity of the sons' expected earnings/income with respect to the earnings/income of their fathers, given that the father belongs to a given fractile group.

Source: Björklund, Roine and Waldenstöm (2012)

55. Figure 17 shows that income earnings and income transmission (that is the intergenerational income elasticity) varies across the income distribution. A $10 \%$ differential in earnings ${ }^{16}$ among fathers belonging to the top $0.1 \%$ is transmitted into a $4.5 \%$ differential among sons, while a $10 \%$ income differential among fathers is expected to translate into a $9 \%$ income differential among sons. The gap between income transmission and earnings transmission suggests that at the top of the distribution capital income is largely derived from inherited wealth, since earnings transmission is much lower than income transmission. Because of transmitted capital income, income mobility at the very top is very low, while being relatively high among low-income earners. Hussain, Bonke and Munk (2011) report similar findings for Denmark: income mobility is lower among top income earners than among the rest of the population. However, income transmission at the top seems lower than in Sweden. It is likely that in countries where equality of opportunity is much weaker than in Sweden or Denmark intergenerational income and earnings transmission impacts even more strongly the income distribution, suggesting that intergenerational top income mobility is quite low.

56. The results from those two studies suggest that intergenerational income mobility is significantly lower at the very top than for the rest of the distribution, despite the fact that Scandinavian countries have very large overall intergenerational earnings mobility compared with other OECD countries (OECD 2011a). To date, there is no similar study using matched father-son pairs for other countries ${ }^{17}$. Using a longitudinal administrative dataset of individual tax returns, Finnie and Irvine (2006) find that in Canada those in the top $0.1 \%$ income group come very disproportionately (around 55\%) from families with income in the top decile, but, owing to data limitations, the authors cannot estimate the intergenerational income elasticity.

\footnotetext{
16. If one individual belonging to the top $0.1 \%$ has earnings $10 \%$ higher than another individual belonging to the top $0.1 \%$, their respective sons' earnings are expected to differ by $4.5 \%$.

17. Few countries have tax datasets allowing for matching fathers and sons.
} 


\section{Explaining the trends in top incomes}

57. Both the academic literature and the public at large have been debating the reasons for the sharp increase in top income shares over the last three decades. As wages and business income now account for a growing fraction of the income of top earners in countries where top incomes grew the most, most explanations focus on the changes in the compensation of labour. Some of them posit that the increase in top income shares is related to market driven changes, while others emphasis the role of changes in regulations and institutions.

\subsection{Market driven explanations}

58. One of the most common explanations of the general rise in income inequality is that increasing globalisation has reduced the prices for goods that are intensive in low-skilled labour (because of increasing competition with countries well-endowed with low-skilled labour) while increasing the demand for high-skilled labour and capital in developed countries. The distributional consequences of globalisation are complex, but according to the standard Hecksher-Ohlin trade theory, openness in capital and highskilled rich countries is expected to result in rising inequality, since high-skilled workers and capital owners benefit the most from the changes in factors prices. A second popular hypothesis is that technical change over the last decades has been skill-biased (see Katz and Murphy 1992) in the sense that modern technology works as complement with high-skilled workers and as substitute for low-skilled workers, thereby increasing the demand for high-skilled labour while reducing the demand for low-skilled workers. This has arguably increased the relative wages of skilled workers compared to unskilled workers ${ }^{18}$. Though these two explanations may partially help understand the trends toward rising inequality for the bottom 99\% (see OECD, 2011a), they fail to explain the dramatic concentration of income at the very top of the distribution and the disjuncture between the top percentile and the rest of the population. A substantial fraction of the population is made up of high-skilled workers in OECD countries and most of them did not see their income growing at the same pace as the income of top earners.

59. The "superstars" theory (Rosen 1981) may help explain the rise in income concentration among high-skilled workers. The main idea is that the very best performers' compensation is determined not only according to their absolute skills but also by their relative quality. Employers want to hire not only skilled workers but the best of them. According to this theory, there is quite a large wage gap between the very best workers and those who are ranked just below them in term of skills. Atkinson (2008) argues that advancing globalisation and progress in information technology have helped make the market for top performers global, increasing therefore the demand for such very skilled and performing workers, whose earnings have increased accordingly.

60. The key problem with these hypotheses is that they fail to explain why top income shares have only grown modestly in countries such as Japan or France which are affected by those global changes as well as English-speaking countries.

61. The change in compensation practices for top executives and financial professionals and the global market for talent may explain to some extent the rise in the income of top earners. As shown by Bakija, Cole and Heim (2012), in 2005 executives, managers and financial professionals account for over 45 percent of the taxpayers in the top percentile (60\% in the top 0.1 percent) and captured $60 \%$ of the increase in the top $1 \%$ share from 1979 to 2005 . This means that they play a key role in the increased top income shares. In English-speaking countries an increasing share of the income of CEO and top executives comes in the form of stock-options, which are considered as wages and salaries in tax returns. Stock

18. For a detailed discussion of the underlying roles of globalisation and technological progress for increasing earnings inequality, see OECD 2011a. 
options were initially designed to align the interest of employees and shareholders and thereby improve efficiency and profitability of firms. There is however a growing concern that stock options are not a completely efficient compensation practice.

62. Another stream of explanations refer to the financialisation of markets. The rise in the share of total income flowing to top earners in English-speaking countries happens to coincide with the rapid development of the financial sector. Philippon and Reshef (2009) show that the skill intensity of jobs in the financial sector has increased dramatically since the early 1980s, resulting in growing wages. This accounts however only partially for the difference between financial sector wages and wages in other industries. They argue that over the past ten years 30 to 50 percent of wage differentials may be put down to rents. However, as shown by Bakija, Cole and Heim (2012) in 2005 financial professionals account for merely $14 \%$ of earners in the top percentile (and receive $16 \%$ of income accruing to the top percentile), which obviously means that rising wages in the financial sector cannot account for the lion's share of the increased top income shares. However, top earners working in other industries may be affected by the financial sector development, partly through the increasingly important role of stock options in top executives' remuneration.

\subsection{Institutional changes}

63. Social norms regarding pay disparity may have quite an important impact on inequality in general and on trends in top income shares in particular. Describing a labour market where individual utility depends not only on income but also on reputation (i.e. conformity with a social code) Akerlof (1980) shows that there may be a long-run equilibrium with a non-market clearing wage. Atkinson (2008) lays out a model in which a pay norm may be (or not) followed by employees and employers, who have to preserve their reputation. Following the norm helps maintain reputation. This leads potentially to two distinct equilibria: one with modest wage differentials if the pay norm is widely accepted and the other with larger income disparity when the bulk of workers and employers do not adhere to the pay norm. The pay norm which used to limit wages disparity in the "Golden Age" has been eroded in the past decades. As a result, a trend toward more unequal distribution of income is observed in a number of OECD countries. Atkinson (2008) argues that such a change might be due to employers attaching more weight to short-run profits than to long-run objectives, including reputation.

64. Some of the cross-country variation may be explained by countries having different pay norms. In Continental European countries public opinion and policy makers are prone to frown on very high compensation of top executive and managers. Acceptability of high salaries at the top has recently come under discussion with the recent economic downturn. Several countries have discussed capping top executive pay and Switzerland, for instance, agreed in a referendum in 2013 to pass a measure that requires listed companies to offer shareholders a binding vote on senior managers' pay and appointments at each annual general meeting.

65. In his study of France, Piketty $(2001,2003)$ underlines the role of progressive taxation in driving the large decrease of top income shares that occurred from the 1920s onwards. Progressive income and inheritance taxation made it difficult for rich people to maintain their wealth and hinder accumulation of new fortunes. Atkinson, Piketty and Saez (2011) survey the main factors behind the decline of top income shares during the 1914-1945 period. The substantial reduction in top rates of personal income tax that occurred over the last three decades in almost all OECD countries (though to a different extent) happens to coincide with rising top income shares. The decline in top rates of income tax leads to a reduction in the tax burden carried by high earners, increasing therefore their post-tax income. Higher disposable income facilitates capital accumulation which down the road results into higher income. Reducing top rates of income tax is also deemed to affect pre-tax income - as measured in tax return. Changes in top tax rates 
trigger a set of behavioural responses that may affect reported income. These reactions go through several channels that will be explored extensively in the following section.

66. Figure 18 suggests that there is a strong negative correlation between the top marginal income tax rate and the share of pre-tax income accruing to the top percentile in almost all OECD countries for which data are available. In all countries the top marginal rate of personal income tax fell over past decades. In 1975 the top tax rates were equal to or above $70 \%$ in half the countries displayed in figure 18 . The tax rate was even above $80 \%$ in the United Kingdom. From 1975 to the mid-2000s top marginal tax rates were reduced in almost all countries, and halved in many countries, including the United States, the United Kingdom and Japan. Along with this spectacular drop in tax rates the share of top earners in total income increased strongly in a number of OECD countries. Even though the two changes seem to be related at first sight, some countries, as Japan and the United States, display similar changes for tax rates but different trends in top income shares.

67. More generally, all forms of taxation affect the income distribution, not only by redistributing income but also by distorting prices and incentives. However, the impact of the different forms of taxation is likely to vary across the income distribution. For instance, VAT changes are deemed to affect less strongly top earners than the rest of the population, while the cost of an increase in inheritance tax rate would typically be borne by the richest. When analysing the impact of taxation on top incomes, attention should be paid to the different components of tax systems. 
Figure 18. Top marginal tax rate and top percentile income share
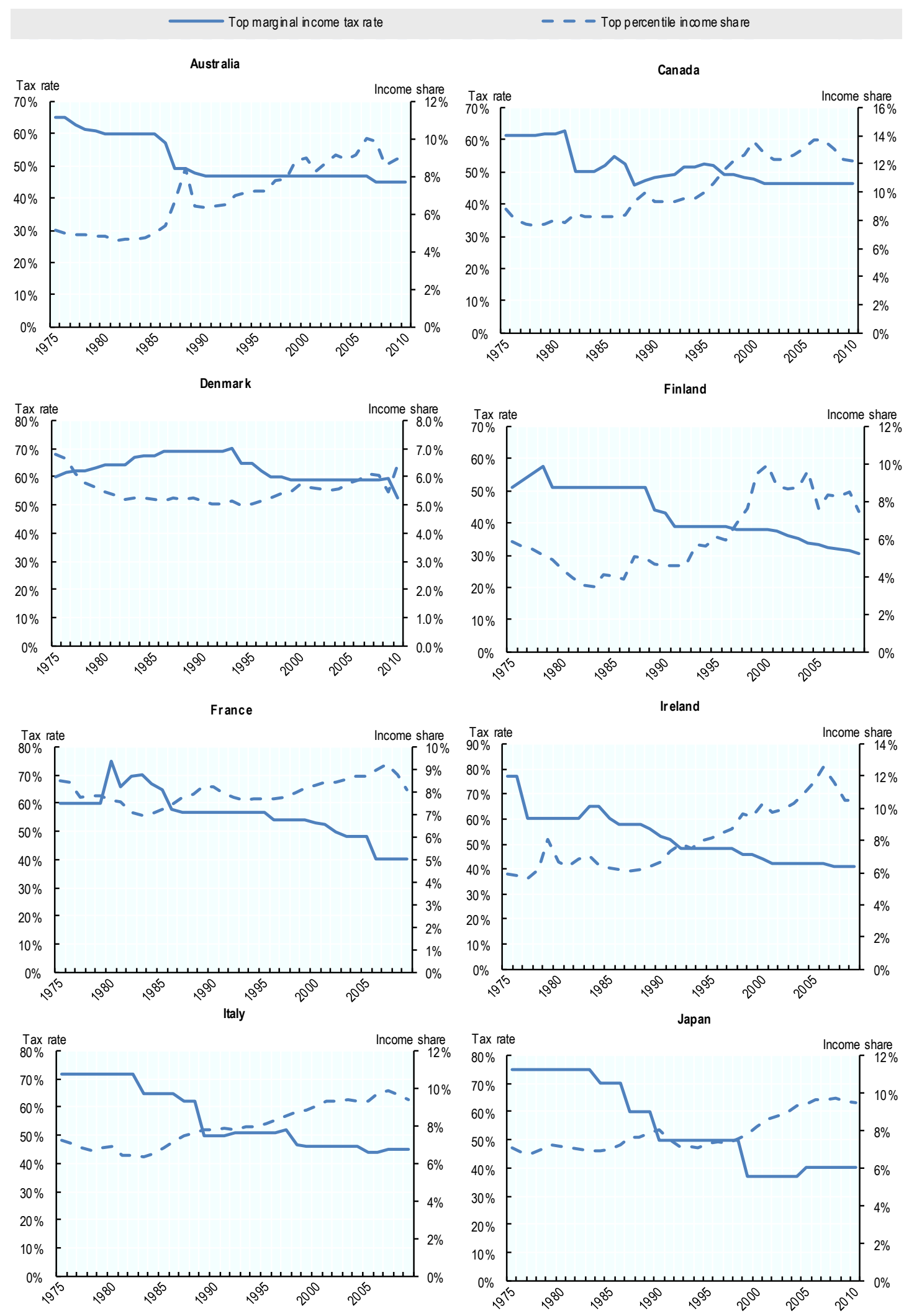
Figure 18 (cont.) Top marginal tax rate and top percentile income share
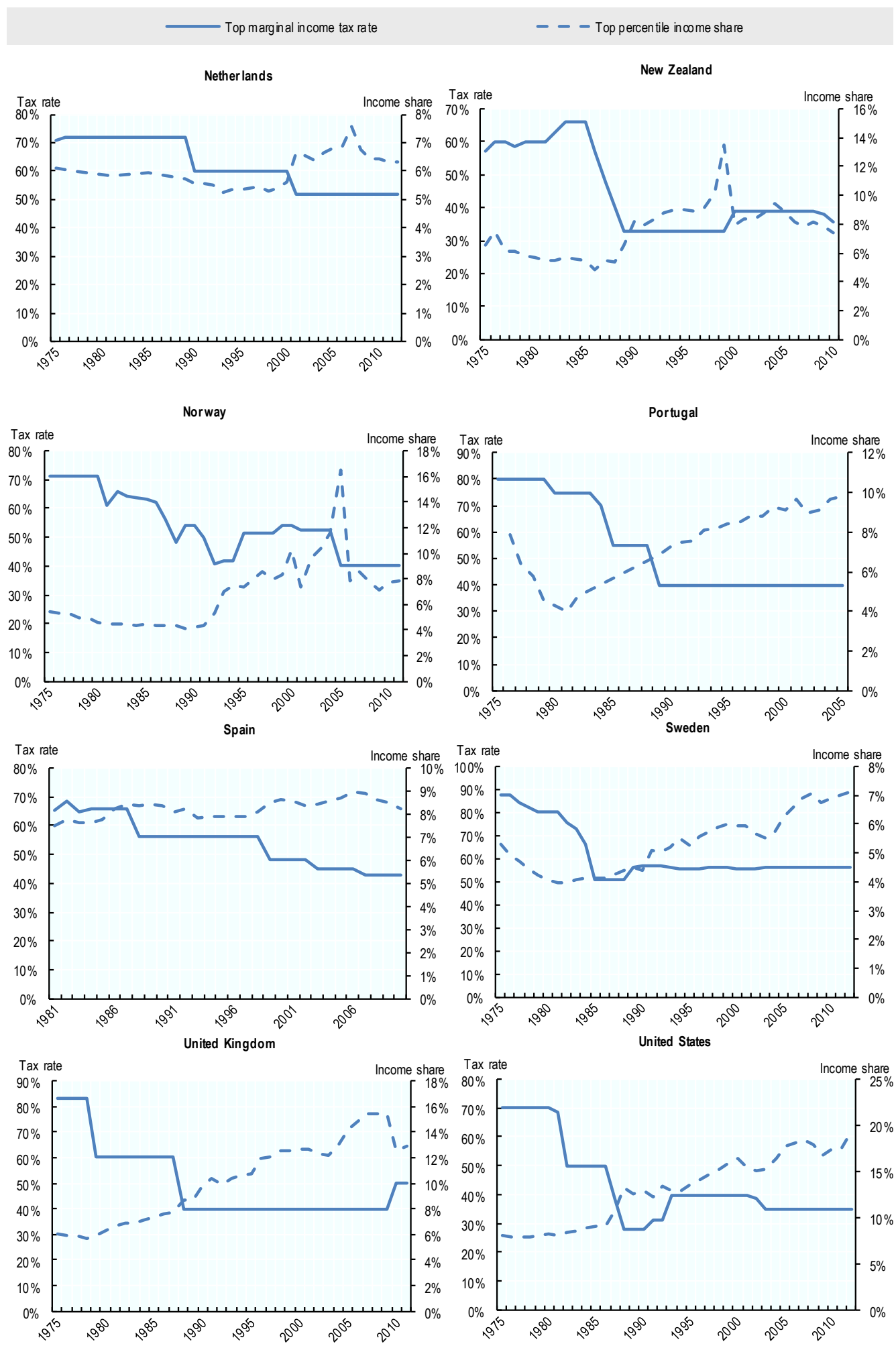

Note: Incomes refer to pre-tax incomes.

Source: tax rates: OECD CTPA; Top percentile income shares: WTID 


\section{Characteristics and trends of taxes affecting top incomes}

68. This section discusses trends in different forms of taxation affecting top incomes. While it remains difficult to assess a causal effect of the changes in tax rates and the rise in top income shares, the previous section suggested an inverse association in many countries between declining top marginal tax rates and rising top income shares. Tax reforms may have induced behavioural changes among top earners, for instance through tax planning responses or through income-shifting across the different income components.

69. The overall income tax burden of high income earners depends on the taxation of the different income components -wages, earnings from self-employment and capital income. In addition, the effect of taxation depends not only on top statutory rates but also on the thresholds where they begin to apply, and is also affected by eligibility to non-standard income tax-reliefs and exemptions. ${ }^{19}$ Both will be discussed in the coming section. The discussion in this section draws heavily on two recent OECD reports prepared by the OECD Centre for Tax Policy and Administration (Brys, Matthews and Owens, 2011; OECD, 2012). Furthermore, this section also discusses capital gains and wealth taxation as wealth may also influence capital income accumulation for top earners.

\subsection{Trends in labour income tax}

\section{The long-term trend}

70. OECD countries have seen a general reduction in their top statutory personal income tax rates (PIT), inclusive of surtaxes and sub-central income taxes. ${ }^{20}$ The OECD-wide average top statutory rate decreased significantly in each of the last three decades: it declined from $65.7 \%$ in 1981 to $50.6 \%$ in 1990 and to $41.7 \%$ in 2010 (Figure 19). ${ }^{21}$ In the late 1970 s it was not uncommon to find top marginal personal income tax rates above $70 \%$ but by the mid-1990s significant cuts in top rates had been made. While the decline was most pronounced during the 1980's, reforms in the past decade resulted in a further reduction of top statutory rates of 7 percentage points or more in 12 countries.

71. The decline in the top statutory rate was not uniform across countries in the past decade. Both the Czech and the Slovak Republic moved to a single-rate PIT structure with their top statutory rate dropping from $32 \%$ to $15 \%$ in 2008 and from $42 \%$ in 2000 to $19 \%$ in 2004, respectively (OECD, 2012b). Five countries (Iceland, Ireland, Portugal, Sweden and the UK) had higher top statutory rates by 2010 while three countries (Austria, Greece and Japan) had identical top rates at the beginning and at the end of the decade.

$19 \quad$ Note that statutory rates differ from the actual rates that individuals pay and they may be higher or lower than average and marginal personal income tax rates. Local taxes, and national surtaxes can raise the actual marginal tax rates above the official stated rate. On the other hand, allowances, exemptions and tax credits can lower the actual marginal tax rate below statutory rates.

Some countries do not have a ceiling for social security contributions (SSC), implying that the SSC rates would be added to the top PIT rate. OECD declined by about three percentage points from $30.5 \%$ to $27.4 \%$ (OECD, 2012). 


\section{Changes during the crisis}

72. As part of measures taken since the economic downturn in 2008, several countries have increased PIT rates, mostly as a revenue-raising measure. If there is a high elasticity of taxable income of top income recipients (see section 6.1 below), the amount of additional revenue might have been limited. Since 2007, 18 OECD countries have increased their top PIT rate, while only 7 countries reduced it during the same period (see annex A.4). In certain countries (e.g. Portugal, France, Italy), the increase focused on highincome individuals by including a surtax on the rate in the highest income bracket. In addition, in 2013, 10 countries are raising their top PIT rates (OECD, 2013a). Japan is planning to increase the top statutory rate from $40 \%$ to $45 \%$ by 2015 . The UK, on the other hand, has reduced its top PIT rate from $50 \%$ to $45 \%$ in 2013, thereby partly reversing the increase implemented in 2010. Some countries have introduced base broadening measures (Australia, Austria, Denmark, the Netherlands), or a reduction in tax credits (France, Greece, the UK) but others have introduced measures that will reduce the PIT tax base through tax credits (e.g. Spain).

Figure 19. Top combined statutory personal income tax rate, 1981-2010

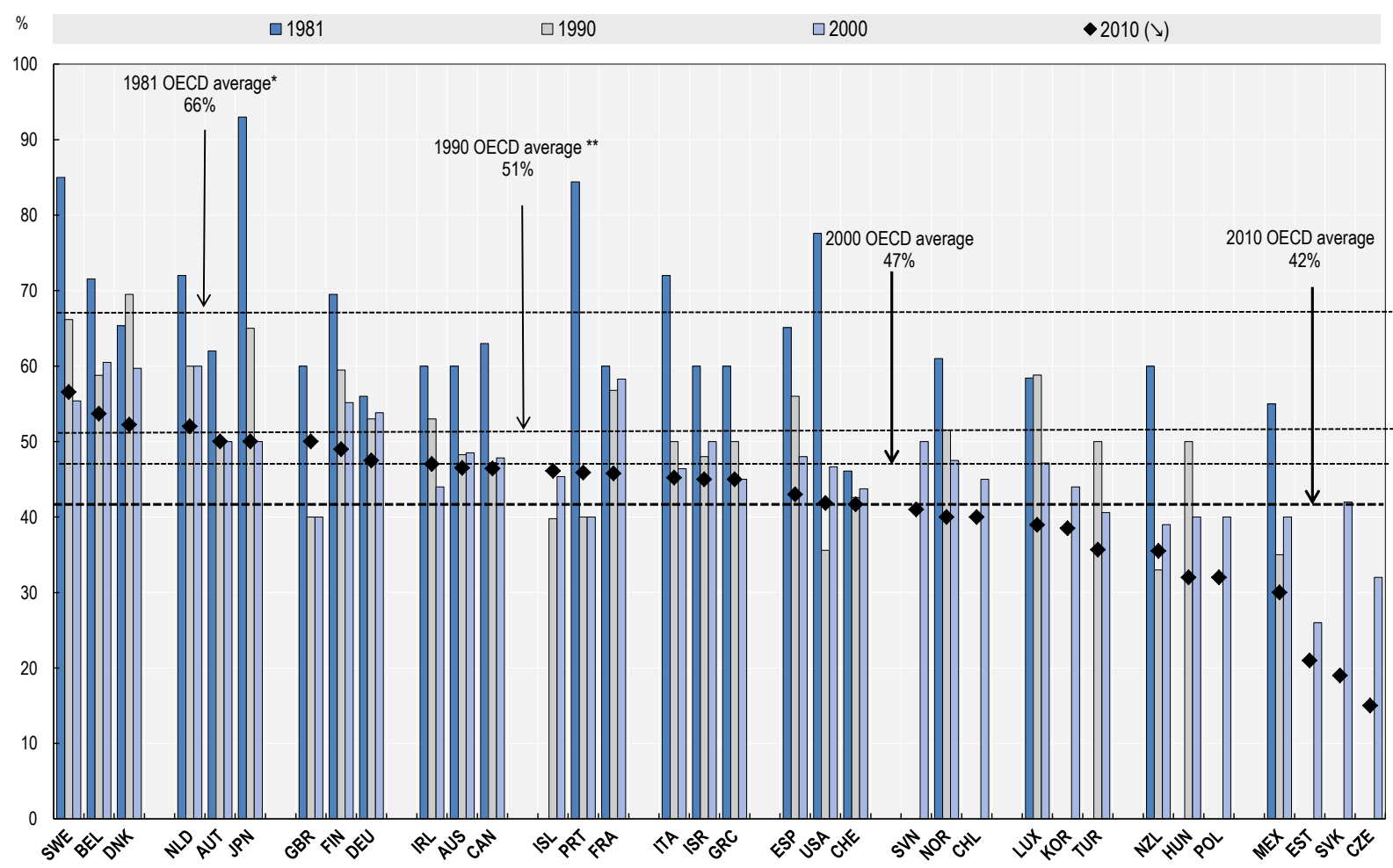

Notes: 1. The sum of the central and sub-central top rates in PIT rate schedule, inclusive of surtaxes and adjusted for the deductibility of sub-central or other income taxes from the central tax base where applicable. 2. Countries are ranked by decreasing top statutory rates in 2010. * Information on data for Israel: http://dx.doi.org/10.1787/888932315602.

* 24-country average. The top rate is not applicable in the Czech Republic, Estonia, Hungary, Poland, the Slovak Republic, Slovenia, and not available for Chile, Iceland, Korea and Turkey.

** 27-country average. The top rate is not applicable in the Czech Republic, Estonia, Poland, the Slovak Republic, Slovenia, and not available for Chile and Korea.

Source: Taxing Wages (2012), OECD 


\section{Changes in thresholds and tax brackets}

73. At the same time, more taxpayers have to pay the top statutory PIT rate on the top slice of their income, as its threshold has fallen in relation to average earnings, though in the majority it is still more than twice the average wage. Overall, the gross income threshold at which the top statutory rate begins to apply decreased from 2000 to 2010 in 20 OECD countries, increased in 11 countries and remained relatively stable in 3 countries. Yet, the threshold at which the top statutory rate applies remains high in countries such as Chile, Portugal and the United States (it applies at earnings more than 16.4 times, 9.7 times and 8.4 times the average wage, respectively). The largest absolute reduction was observed in Mexico from applying a threshold at 49.8 times in 2000 to 4.5 times the average wage in 2010. In relative and absolute terms, the threshold declined heavily in the Czech and Slovak Republic (by more than $80 \%$ ), in Slovenia and Turkey (by more than 60\%) and in Belgium, Korea, Luxembourg and Spain (by more than 40\%). Greece, Japan and Sweden experienced small changes while several countries increased the threshold at which the rate begins to apply (Germany, Ireland, Israel, Portugal and the United Kingdom).

74. Trends in top statutory rates, thresholds and tax brackets have tended to move in the same direction. The threshold at which the top combined statutory personal income tax rate begins to apply tends to be highest in countries with a large number of tax brackets. Many countries reduced the number of tax brackets significantly during the 1980s and 1990s and this trend has continued in the 2000s (Figure 20). The threshold for the top combined rate decreased in 11 of the 13 countries where the number of tax brackets was reduced between 2000 and 2010 while it increased in 6 of the 9 countries for which the number of central tax brackets increased (OECD, 2012b). There are, however, exceptions such as Australia, Canada, Denmark, Estonia, Germany, Hungary and Israel, where the threshold increased while the top rate decreased.

\section{Figure 20. Income threshold where the top combined statutory tax rate is levied}

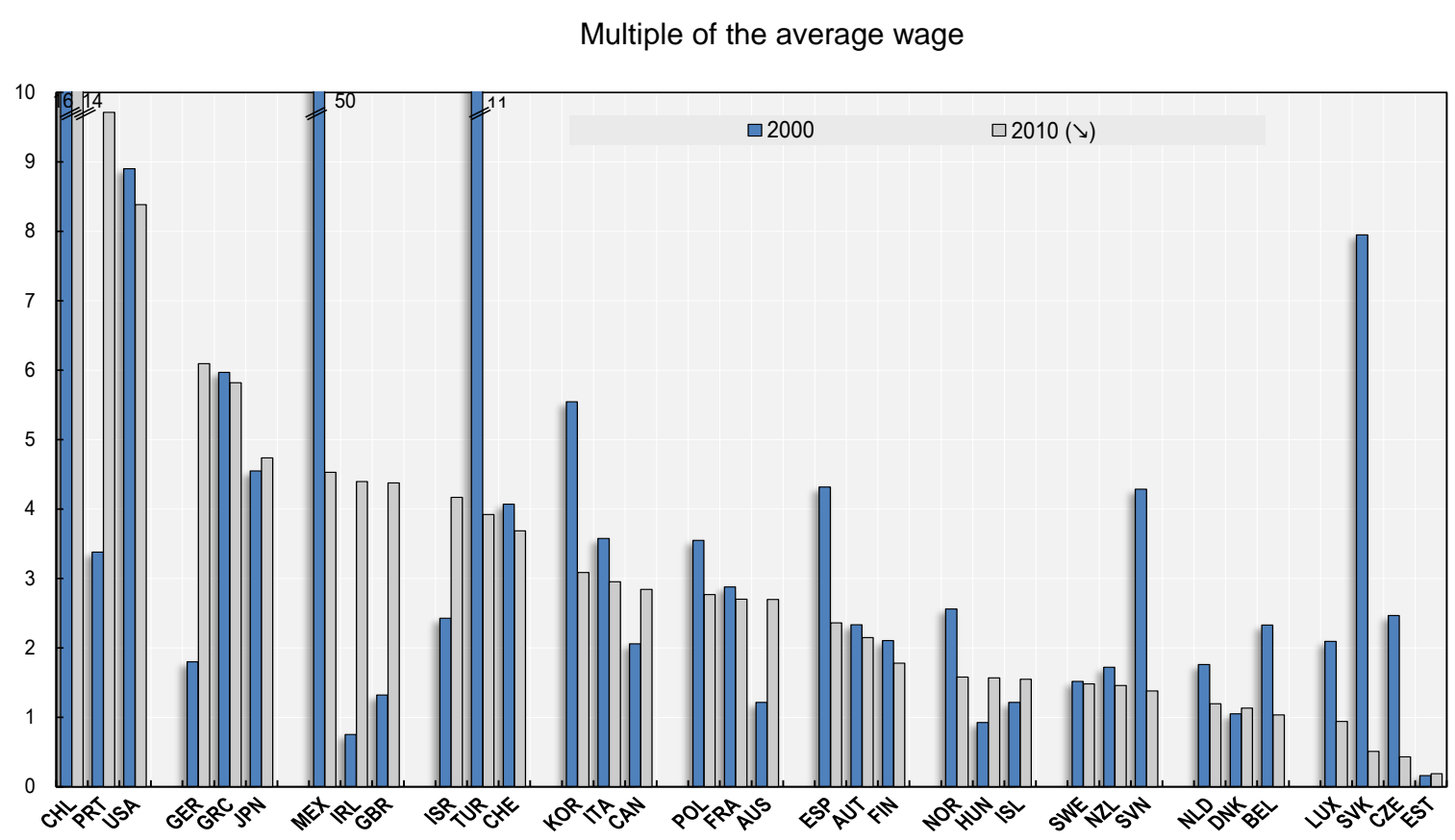

Notes: 1 . Multiple of the average wage where the top combined central and sub-central personal income tax rate begins to apply for a single individual claiming only standard tax allowances. For the Czech Republic, the 2010 figure denotes the threshold where a single taxpayer begins to pay tax. 2. Countries are ranked by decreasing threshold in 2010 . * Information on data for Israel: http://dx.doi.org/10.1787/888932315602.

Source: OECD Taxing Wages (2012) based on (www.oecd.org/ctp/taxdatabase). 


\subsection{Capital income tax}

75. For certain professions, it is possible to incorporate their activities and be considered as selfemployed rather than an employee; this choice is partly influenced by the relative taxation of wages versus distributed profits from a corporation. Likewise, capital income may be taxed at the individual and at the corporate level and the distribution may be influenced by double taxation of dividends and treating corporations and investors as separate entities. Imposing corporate income tax reduces the opportunities to shelter income from taxation and allows for the taxation of economic rents (OECD, 2008). Corporate tax reduces tax-induced incentives for businesses to incorporate and transform highly-taxed labour income into lower-taxed capital income. It also acts as a withholding tax on equity income earned by non-residents. Finally, if corporate taxes apply only to economic rents in excess of normal return, they will not create efficiency losses, although it is difficult to define what constitutes rents, and corporate taxes still influence profit-shifting decisions between high and lower-tax jurisdictions.

76. Increases in marginal tax rates for labour may result in shifts to other forms of taxable income such as corporate income, or deferred compensation; vice-versa, declines in the taxation of corporate income provide incentives for an increased declaration of part of income as capital or business income. For instance, there is some evidence that part of the increase in top individual incomes after the US Tax Reform Act of 1986 was due to a shift from the corporate sector toward labour income as individual income tax rates were reduced relative to corporate tax rates (Gordon and Slemrod, 2000). Atkinson and Leigh (2010) found that a 1 percent decrease in the median tax rate on capital income paid by the top percentile is associated with a 1.5 percent rise in the income share of the top percentile group.

77. Greater international mobility has increased tax competition and put downward pressure on other forms of taxation which affect the top income percentile. Corporate tax rates have declined, partly as a response to the greater mobility of investment and partly to reduce inefficiencies. The trend towards a reduction of corporate income tax rates started with the tax reforms in the United Kingdom and the United States in the mid-1980s which broadened the tax base and cut statutory tax rates (Brys et al., 2011). Statutory corporate income tax rates have declined by 30 or $40 \%$ in many countries since 1981 (Figure 21). In the past decade, the OECD-average rate dropped by 7 percentage points, being reduced in 31 countries and increased only in Chile and Hungary, while staying constant in Norway. At the same time, to compensate for revenues lost, most OECD countries have broadened their corporate tax bases through a reduction in the generosity of allowances, and the elimination of tax deductions and provisions. Average effective corporate tax rates have nonetheless declined over time. 
Figure 21. Statutory corporate income tax rates

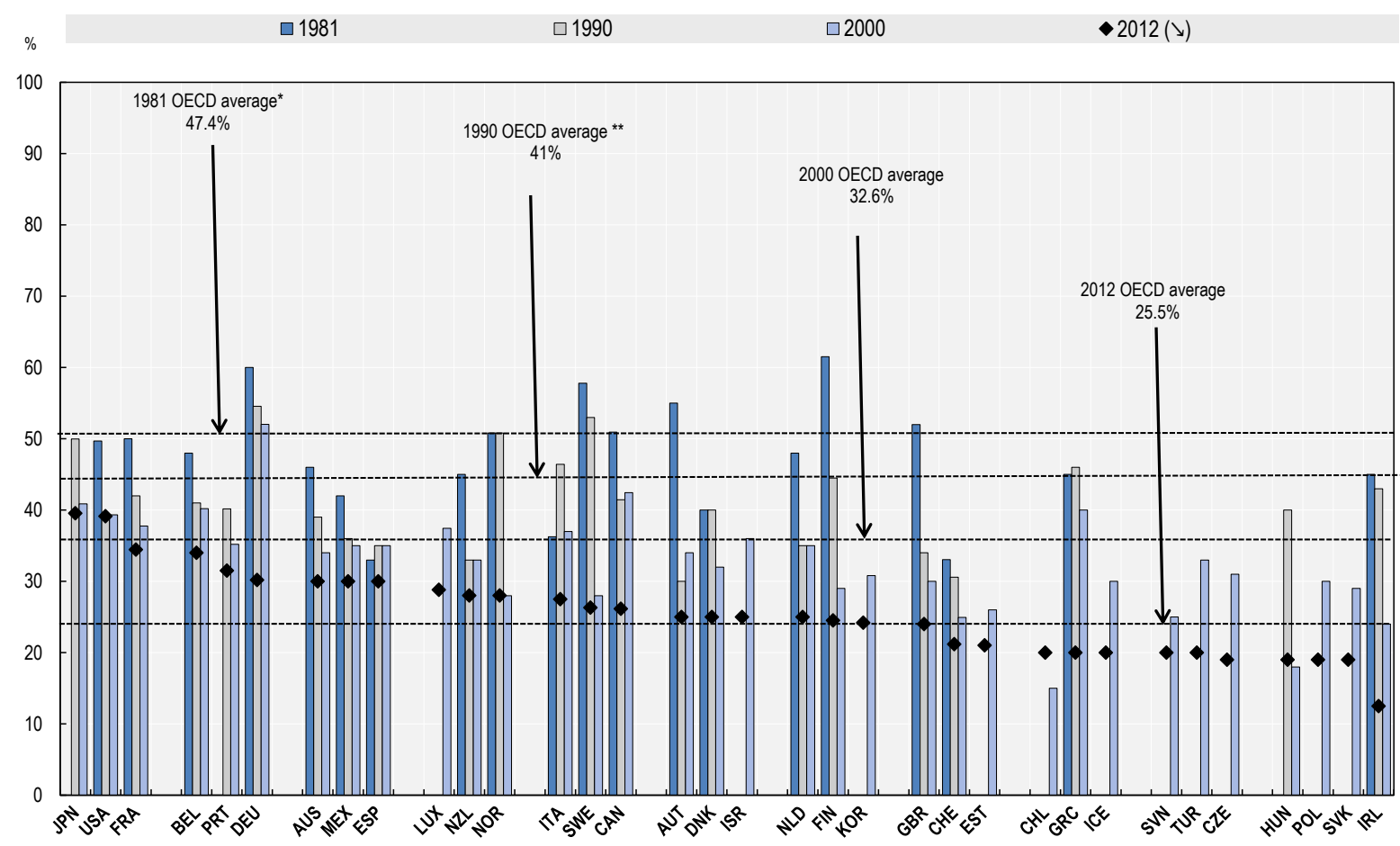

Note: The basic combined central and sub-central statutory corporate income tax rate. Data ranked by 2012 . Sub-central government taxes are also included; for the United States, it is based on a weighted average of state marginal corporate income tax rates.

* 21-country average. The top rate is not applicable in the Czech Republic and the Slovak Republic and not available for Chile, Estonia, Korea, Iceland, Israel, Hungary, Japan, Luxembourg, Poland, Slovenia, and Turkey.

** 23-country average. The top rate is not applicable in the Czech Republic and the Slovak Republic and not available for Chile, Estonia, Korea, Iceland, Israel, Luxembourg, Poland, Slovenia, and Turkey.

* Information on data for Israel: http://dx.doi.org/10.1787/888932315602.

Source: OECD Tax Database (www.oecd.org/ctp/taxdatabase).

78. Since the start of the recession, the downward trend on CIT rates has continued but slowed. On average, rates fell 0.8 percentage points per year from 2000 to 2007 , but only 0.4 percentage points per year since (OECD, 2013a). Some countries (e.g. Iceland, Portugal) have even increased corporate statutory tax rates in recent years. Nevertheless, a number of countries (19 in total) have continued to decrease rates since the crisis. Some countries have broadened their tax base (via restrictions on interest rate deductibility and loss carry-forwards) while others have introduced base-narrowing reforms (accelerated depreciation, enhanced incentives for research and development).

79. On the other hand, since the onset of the crisis, more than half of the OECD countries have increased personal income taxes on capital (e.g. France, Portugal, Spain, the US) while others are reducing ceilings for tax privileged savings (e.g. Ireland, the UK).

80. The rate of personal taxation on dividends has fallen in recent years, largely as a result of falls in corporate income tax rates, though there have also been cuts in the rates of personal income tax applied to dividends. Top marginal tax rates ${ }^{22}$ on dividends take into account the fact that profits are taxed both at the corporate level (where the assumption is that they bear the statutory corporation tax rate) and again when 
they are distributed as dividends. On average, the top marginal tax rate on dividends in OECD-countries was $75 \%$ in 1981 for the selection of countries for which information was available while the OECD-wide average was $42.5 \%$ in 2012 (Figure 22). Reductions have occurred throughout the past decades, although they were quite pronounced between the 1980s and the 1990s as it was not uncommon in 1981 to have overall statutory rates in excess of 70 or $80 \%$. In the past decade, rates on dividends have declined on average by slightly less than 7 percentage points.

Figure 22. Overall statutory rates on dividend income for distributions of domestic source profits

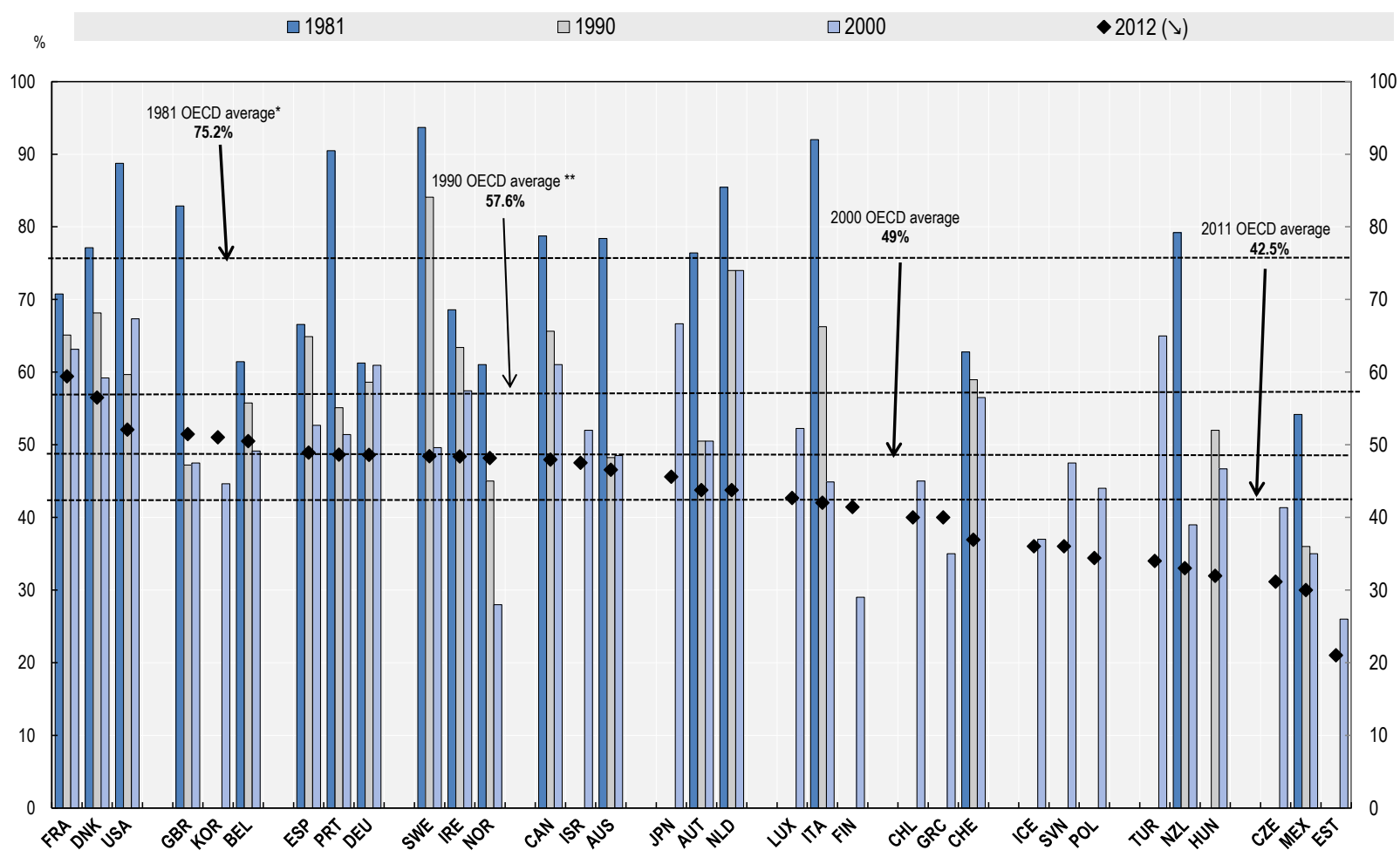

Notes: This tax rate is the overall top marginal tax rate (corporate and personal combined) on distributions of domestic source profits to a resident individual shareholder, taking account of imputation systems, dividend tax credits, etc. Sub-central government taxes are also included; for the United States, it is based on a weighted average of state marginal corporate income tax rates and state marginal income tax rates on dividend income.

* 19-country average. The top rate is not applicable in the Czech Republic, Finland, Greece, Hungary, Iceland, Japan, Korea, Luxembourg, Poland and Turkey and not available for Chile, Estonia, Israel, and Slovenia.

** 20-country average. The top rate is not applicable in the Czech Republic, Finland, Greece, Iceland, Japan, Korea, Luxembourg, Poland and Turkey and not available for Chile, Estonia, Israel, and Slovenia.

* Information on data for Israel: http://dx.doi.org/10.1787/888932315602.

Source: OECD Tax Database (www.oecd.org/ctp/taxdatabase).

\section{Taxes on dividend income from ordinary shares, interest and capital gains}

81. Many individuals do not generate capital income from their own business activity, but they may have capital income from holding funds in deposit accounts or bonds, and/or from the ownership of equity or real property. Preferential tax treatment of household capital income may underestimate the importance of capital income. Earnings on investments of pension funds and life insurance, and imputed rents on owner-occupied dwellings are often exempted from taxation, and, similarly, in some cases dividends and interest receipts may receive a preferential tax treatment (Carey and Rabesona, 2002). For the five countries - France, Germany, the Netherlands, Spain, the United Kingdom and the United States - for 
which data were available, it was estimated that taken together all adjustments for preferential tax treatment of personal capital income substantially reduce the capital income tax ratio -- by 8 percentage points, on average -- and significantly increase the labour income tax ratio -- by 4 percentage points, on average). These effects are especially large in Germany and the United Kingdom (Carey and Rabesona, 2002). The non-taxation of imputed rentals on owner-occupied housing, in particular, reduces the capital income tax ratio by an important percentage while adjusting for special tax treatment of household dividend income has implications for Germany and Norway and the United Kingdom.

82. New OECD analysis (OECD 2011b) has estimated the statutory tax rate on dividend income from ordinary shares and interest income from cash deposits and government bonds. The combined statutory tax rates on dividend income depend on the tax systems and rates that apply at the corporate and shareholder level as well as on the interaction between these tax systems. As dividends are taxed firstly as corporate income and then distributed to the shareholder where they may be taxed again as personal income, a critical factor in determining the overall rate of tax that applies will be the integration of corporate tax paid at the personal level (see OECD, 2011b for a detailed discussion on how taxation at the corporate and individual level are done). Figure 23 shows that the estimated tax rate on dividends ranges between $20 \%$ to over $50 \%$, while the tax rate on interest is sometimes $0 \%$ to up to $50 \%$. Personal tax rates on dividends, interest and gains have increased in a number of countries since the economic downturn.

Figure 23. Estimated tax rate on dividend income from ordinary shares and interest (2011)

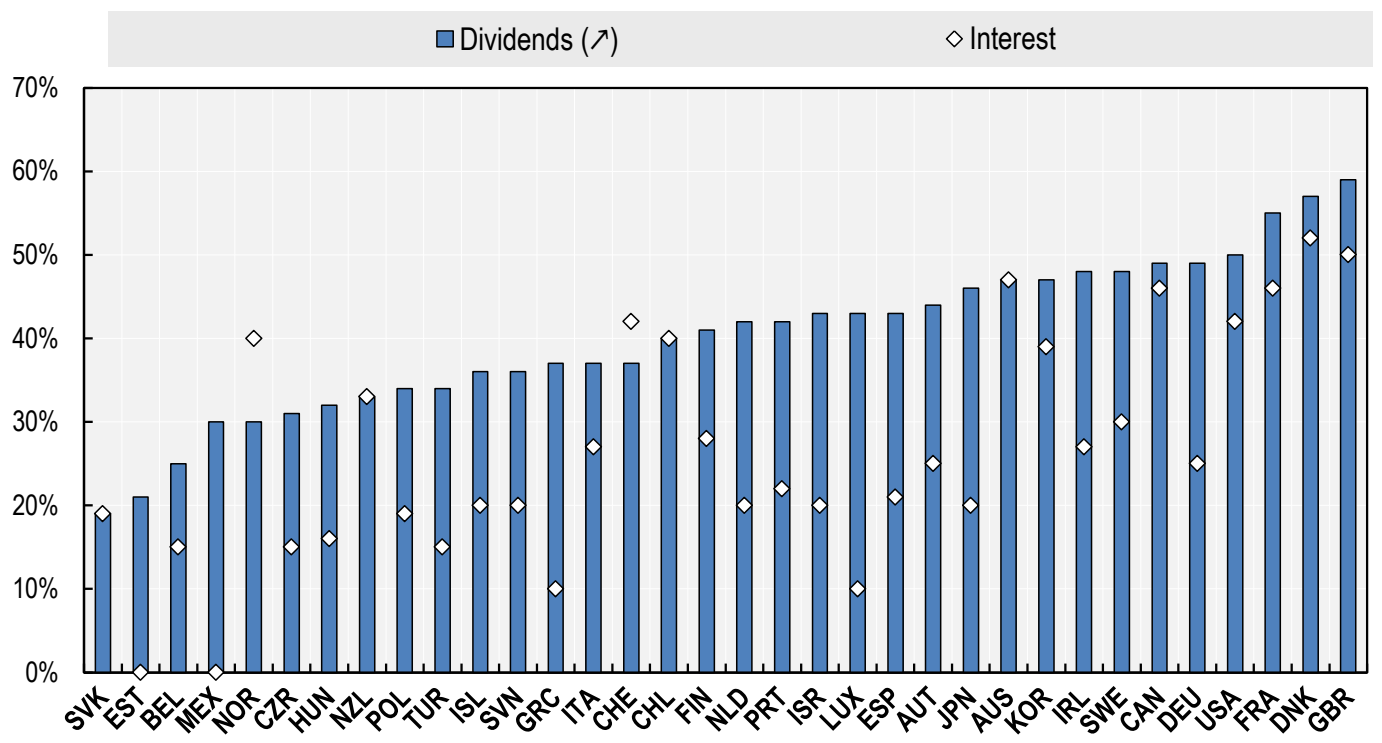

* Information on data for Israel: http://dx.doi.org/10.1787/888932315602.

Source: OECD, 2011b.

83. Figure 24 displays the estimated statutory tax rate on capital gains made on shares and real property. In OECD countries, capital gains are not taxed on accrual but on realisation of the gain, that is, when the asset is sold, gifted or bequeathed to another owner. The estimated effective tax rate on capital gains on shares takes into account both the corporate and personal tax payable on these gains. Effective tax rates on capital gains on shares vary considerably across OECD countries, ranging from $12 \%$ in Belgium to more than 55\% in Greece and Denmark. In around half of OECD countries, capital gains made on shares are only subject to the corporate income tax. As for dividend income, capital gains made on shares are taxed first at the shareholder level before being distributed to the shareholders. Corporate income tax rates range from $12 \%$ in Belgium to $39 \%$ in the United States. In most countries the effective tax rate is higher on capital gains made on shares than on property. Many countries do not tax capital gains made on 
property. Those are generally countries where the capital gains made on shares are not heavily taxed at the personal level. Notable exceptions are Korea, Norway and Switzerland, as in those countries capital gains made on property are more heavily taxed than gains made on shares. At the same time, several countries are planning modifications to the taxation of capital gains as of 2013. For instance, in France, capital gains on securities and capital income will be included in the PIT base, Spain will include capital gains derived between May and December 2012 in the general tax base, while Ireland, Portugal, Slovenia and the US have recently increased the rate on capital gains.

Figure 24. Estimated statutory tax rate on capital gains

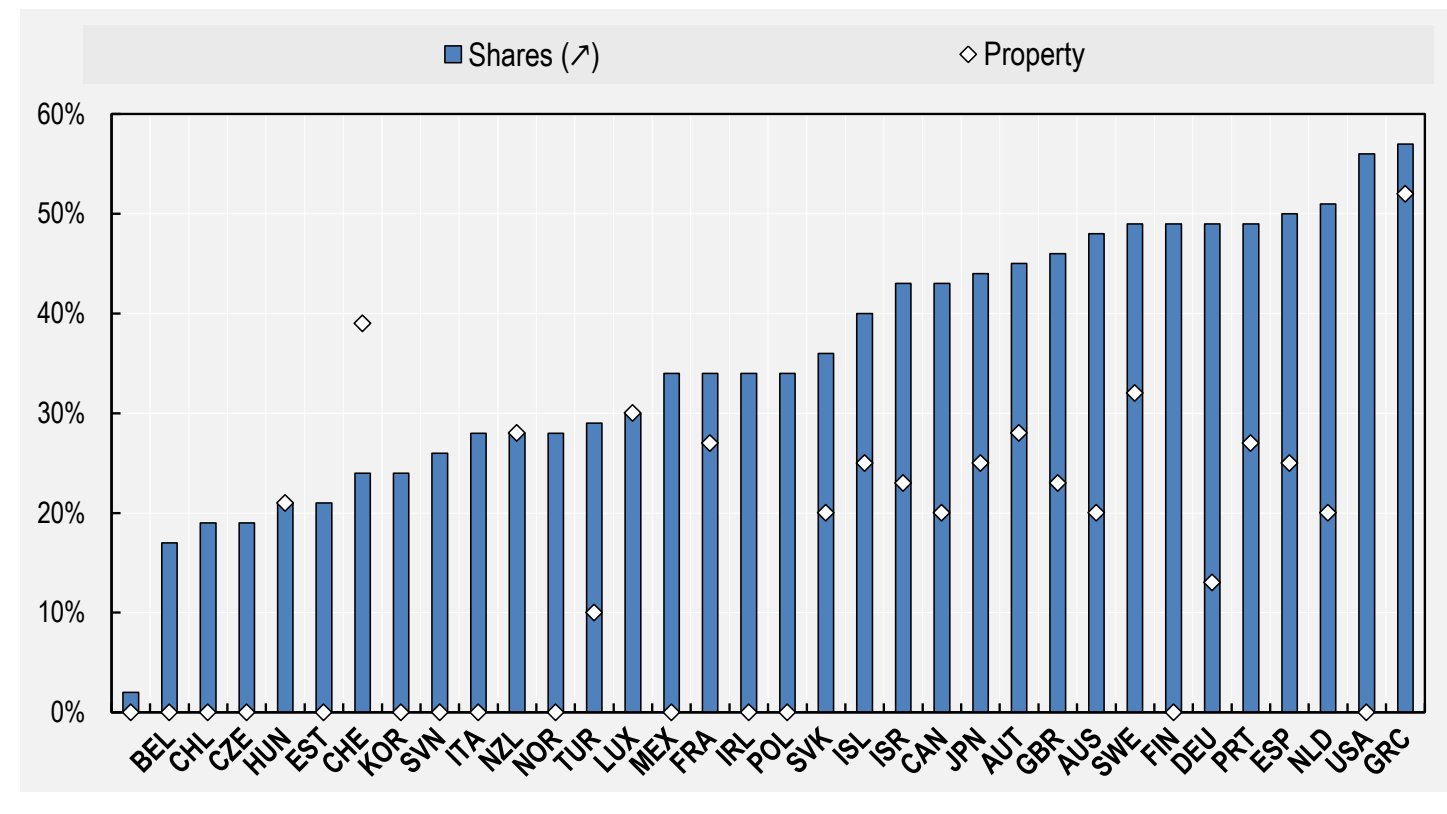

* Information on data for Israel: http://dx.doi.org/10.1787/888932315602.

Source: OECD, 2011b.

84. Taxes on capital gains affect primarily top income earners, as capital gains are concentrated at the top of the income distribution. However, estimating precisely the distribution of capital gains is challenging as capital gains are imperfectly measured in personal income tax returns. In many countries, capital gains are not taxed at the personal level and therefore are not reported in the individual tax return.

85. Most of the top income shares series documented above exclude capital gains from the definition of income. For five countries, two different series including or excluding realised capital gains are available. Figure 25 displays the evolution of the share of income accruing to the top 1\%, depending on whether capital gains are included in total income. Unsurprisingly, the share of income going to top groups is larger when income includes capital gains ${ }^{23}$. The top $1 \%$ shares including capital gains are also more volatile, as capital gains are very responsive to business cycles and changes in tax policy. For instance, capital gains realisation may be brought forward or postponed so as to benefit from more favourable taxation. The gap between series including and excluding capital gains varies across countries: it is much less pronounced in Canada than in Sweden or in the United States.

23. Ranking of individuals may dramatically change when including capital gains in the definition of income, since fractiles defined by total income including capital gains are not the same as those defined excluding capital gains. 
DELSA/ELSA/WD/SEM(2014)5

Figure 25. Top income shares including and excluding capital gains, 1970-2012

Top 1\% income share-excluding capital gains

Canada

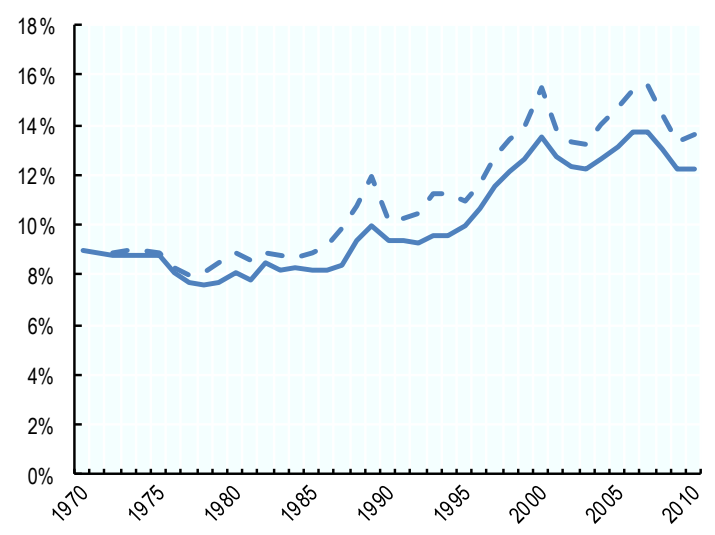

Japan

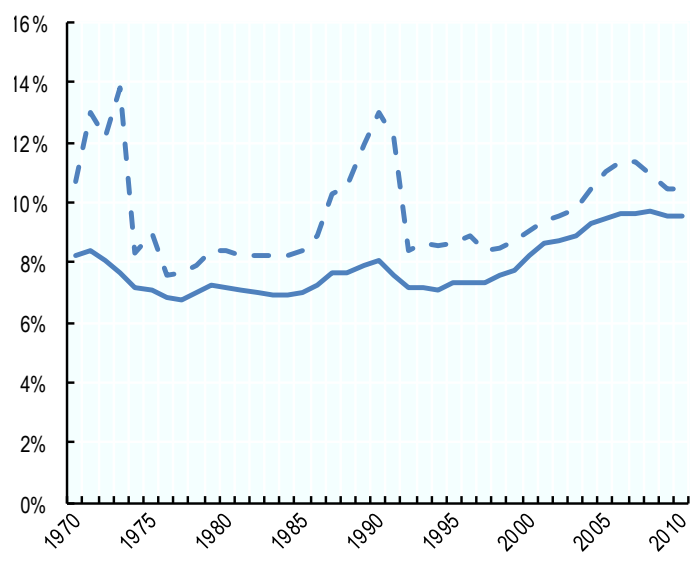

Sweden

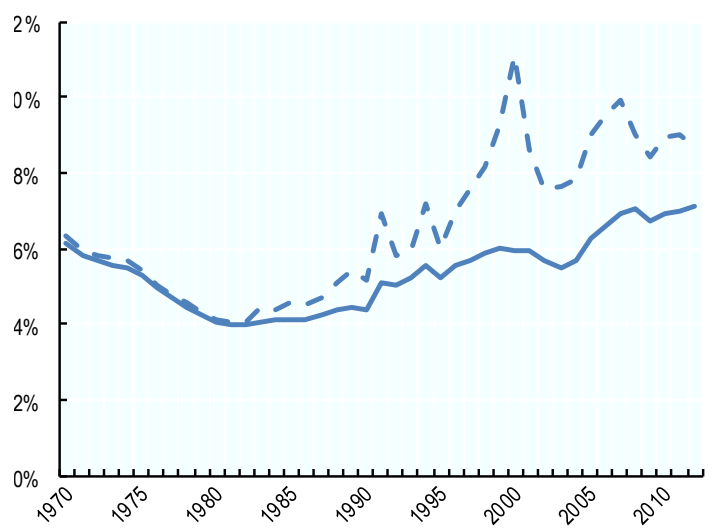

- - - Top $1 \%$ income share-including capital gains

Germany

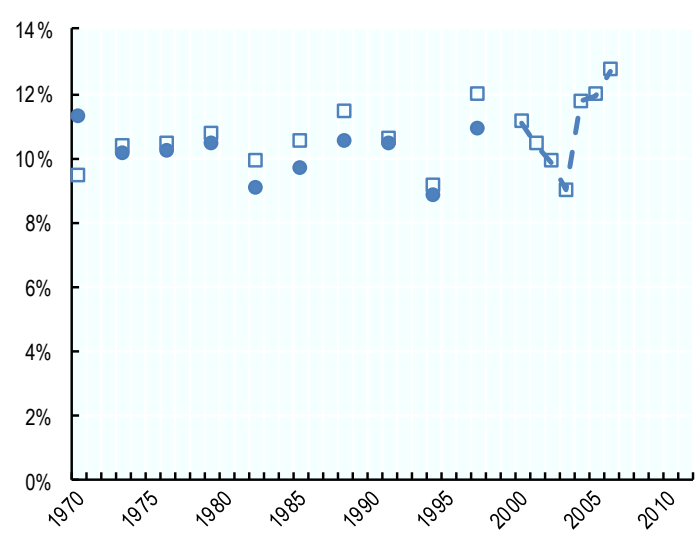

Spain

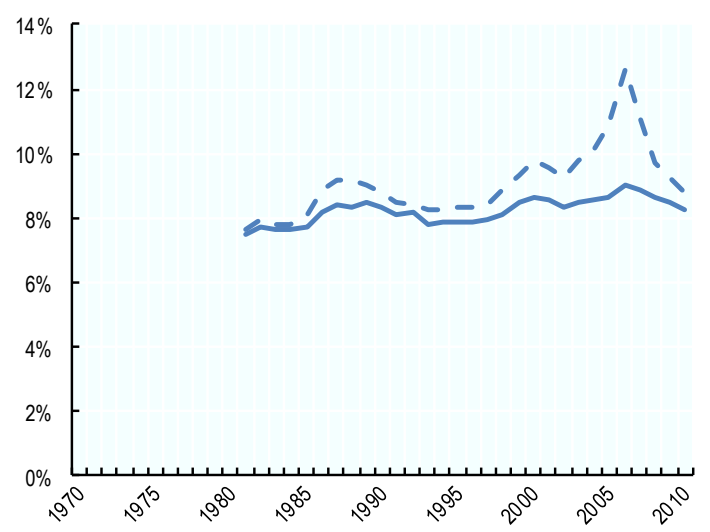

United States

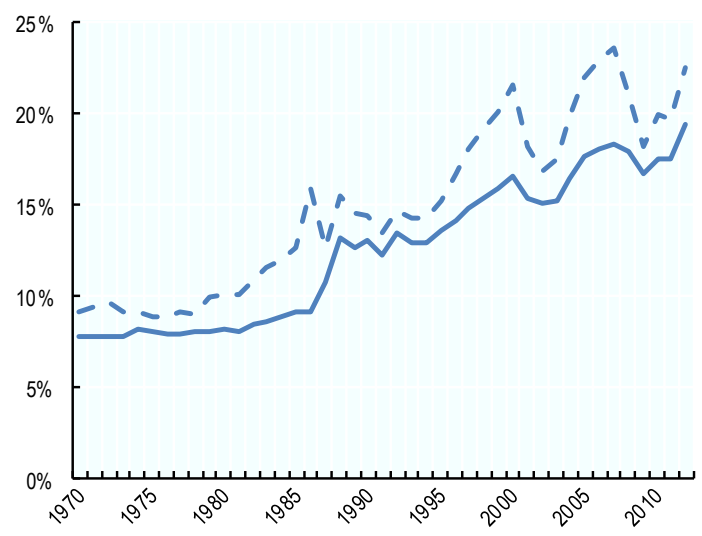

Note: Incomes refer to pretax incomes.

Source: World Top Incomes Database

51 
86. Figure 26 shows the share of capital gains in total income for the top percentile and the top $0.01 \%$ in Canada and the United States. In general, the share of capital gains is higher for the top 0.01\% than for the top percentile. The share of capital gains has evolved similarly for both groups over the recent decades. The impact of the 1986 tax reform, which increased the tax rate on realised capital gains, is striking. The tax reform resulted into a pike in 1986 followed by a dramatic decline in capital gains the years after the tax reform, suggesting that capital gains are highly sensitive to changes in the tax system. The share of capital gains in total income is also sensitive to business cycles, increasing in time of economic expansion and falling during recessions.

\section{Figure 26. Capital gains as a share of total income}

$\begin{array}{cc}\longrightarrow & --- \text { Top } 0.01 \% \\ \text { Canada } 1 \% & \text { United States }\end{array}$
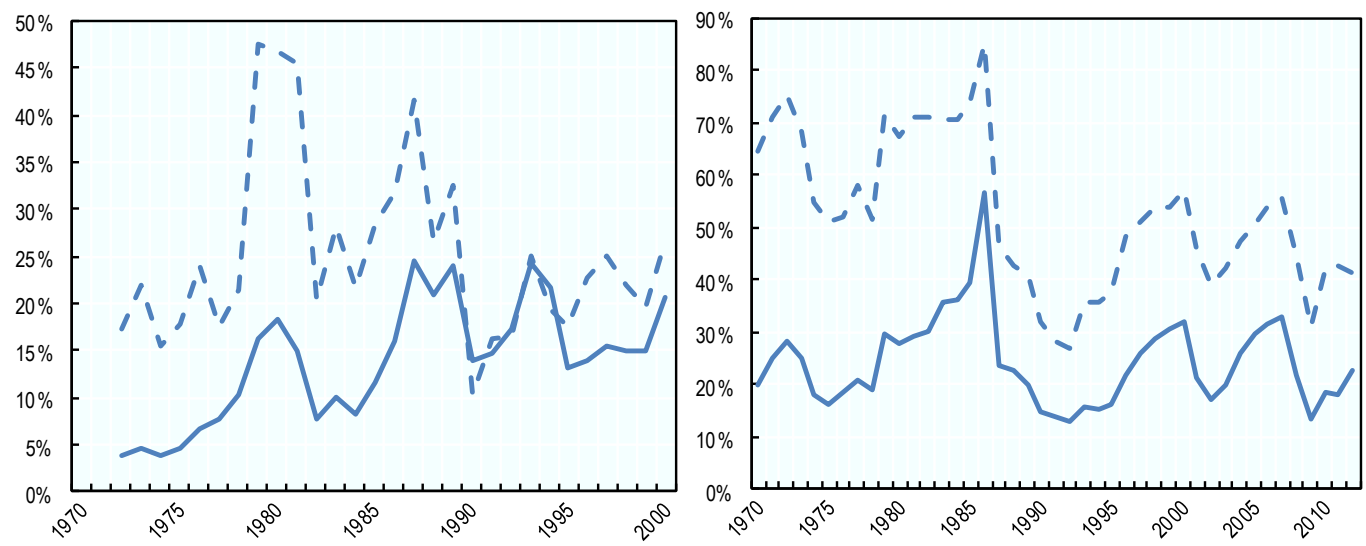

Note: Incomes refer to pre-tax incomes. Fractiles are defined by total income including capital gains.

Source: World Top Incomes Database.

\subsection{Beyond income: taxing wealth}

87. What is the relevance of looking at wealth-related taxes when analyzing the taxation of top income earners? One of the first rationales for wealth taxes relies on the assumption that in many countries not all income is taxed, particularly because some capital gains are not taxed or taxed at low rates when sold (Gale and Slemrod, 2001). Net wealth taxes can be a backup to personal income taxes since they provide tax authorities with information that enables them to identify inconsistencies between income flows and wealth held by taxpayers. In addition, the fact that marginal rates of income tax have fallen in OECD countries over recent years implies that top income groups are able to keep a higher proportion of their income. This means that it is easier for richer people to accumulate wealth, and this could lead to increases in their capital income in the future. Box 4 shows the share and the evolution of wealth concentration for a selected number of OECD countries for which data are available. 


\section{Box 4. Wealth Concentration}

Tax data on wealth distribution are much scarcer than data on income and unfortunately available only for a limited number of countries. Top wealth shares are generally computed with wealth or estate tax returns. Wealth distribution is admittedly more unequal than income distribution, as many people have little if any wealth at all. At the beginning of the twentieth century, wealth was highly concentrated at the top. At that time, the top percentile used to own around $65 \%$ of total wealth in France (Piketty, Postel-Vinay and Rosenthal 2006), 55\% in Sweden (Roine and Waldenström 2009), 38\% in the United States (Kopczuck and Saez 2004) and 47\% in Switzerland (Dell, Piketty and Saez, 2005). In many Western countries, there has been a sharp decline in wealth concentration over the first half of the twentieth century. The main factors driving this dramatic decline in wealth concentration are the destruction of physical capital caused by the two world wars, the fall in asset prices that took place in the 1930s and the introduction of progressive taxation. The decline in wealth concentration documented for other countries did not happen in Switzerland, where wealth concentration has been more or less constant over the twentieth century. This is not surprising, since Switzerland did not actively take part in any of the two world wars and did not impose very high income tax rates compared to most Western countries.

\section{Figure 27.Top $1 \%$ wealth share}

A. Wealth Concentration in 2000

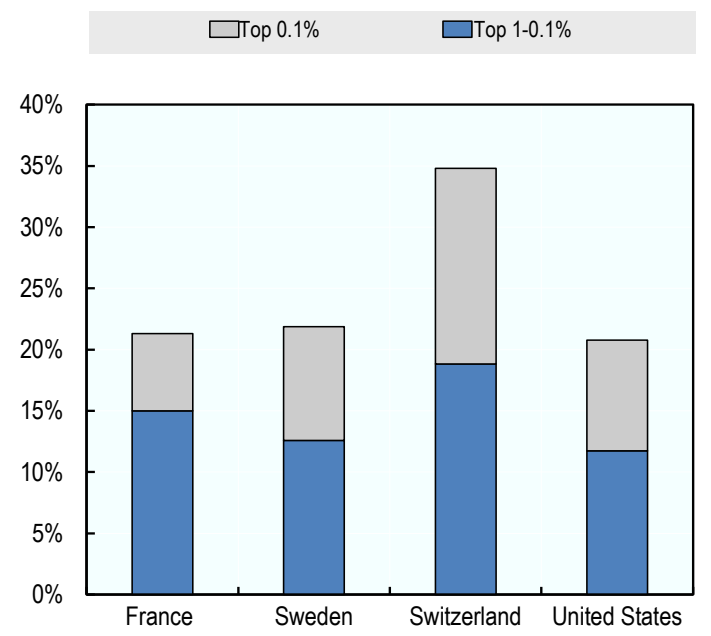

B. Top 1\% Wealth Share over Time

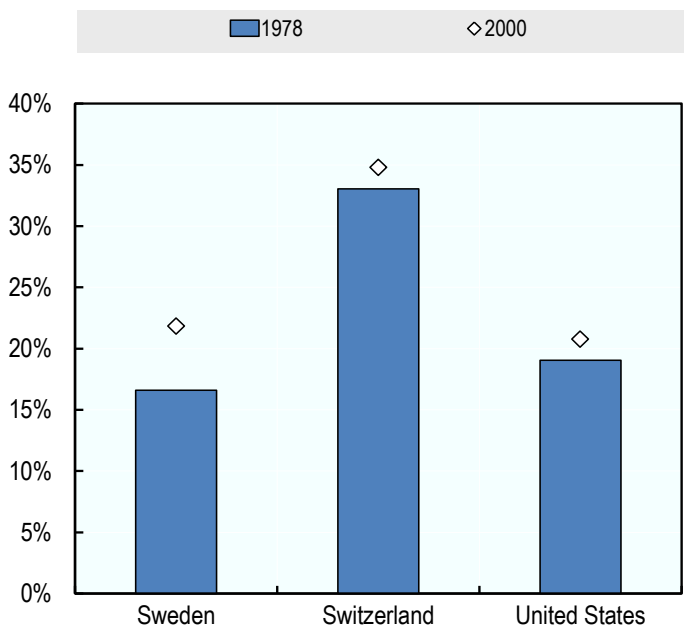

Notes: France 1994; Switzerland: 1981 and 1997

Source: France :Piketty \& ali (2006); Sweden : Roine \& Waldenstöm (2009); Switzerland: Dell \& ali (2005); United States : Kopczuk \& Saez (2004)

As shown by figures $A$ and $B$, the top $1 \%$ wealth share is much higher in Switzerland than in any other country for which data are available. In France, Sweden, and the United States the top $1 \%$ own between $20 \%$ and $25 \%$ of the total national wealth. These countries display similar wealth concentration, while income concentration at the top of the distribution is much more pronounced in the United States. In Switzerland and in the United States the top 1\% wealth share has been fairly constant over the past three decades (though it has increased slightly in the late 1980s in the United States), while income concentration has increased substantially in Sweden. One may wonder why wealth concentration has not increased that much in the United States while the top 1\% income share has gone up dramatically over the same period. Increasing income concentration at the top could entail large wealth accumulation and concentration, as the saving rate of top earners is typically much higher than of the average income earner. The absence of increased wealth concentration may be due to income mobility being relatively high: if many of those in the top percentile in a given year do not remain in this group the following year, then rising income disparity does not necessarily result into stronger wealth concentration. Exit rates from the top $1 \%$ were, however; lower in the US than in other countries (see section 3.3). Moreover, tax system progressivity may hinder wealth concentration. Piketty (2001) argues that progressive income tax slows down wealth accumulation (by decreasing the net-of-tax return on capital and the take-home pay) and may consequently prevent excessive wealth concentration at the top of the distribution. Progressive inheritance tax limits the development of capital dynasties. In the case of the US, another possible explanation is related to the fact that the rise in top incomes is linked to a growing share of labour and business earnings (though this trend ended in the US in the past decade). It is therefore possible that this new group has not had time to accumulate a large wealth stock because of low saving rates or too recent pay increases (Kopczuk and Saez, 2004). 
Unfortunately data on top wealth shares are available only up to 2000 . The picture may look differently today. Moreover, this discrepancy might stem from top wealth shares being computed using estate data: as those benefiting from increasing income growth are mostly top executives that have not died yet, estate Tax data may not yet reflect how the growing income concentration impacts the wealth distribution. This may hide a more considerable increase in wealth concentration in the medium-term.

88. Ideally, in order to assess the relation between income and wealth concentration over time, estimates of the joint distribution of (top) incomes and (top) wealth would be needed. Such analyses remain, however, rare and restricted to country-specific studies. Atkinson and Søgaard (2013), for instance, analyse the joint distribution of income and wealth in Denmark from the 1980s onwards by estimating the wealth-to-income ratios with individuals ranked according to their taxable income. Over the last three decades, the wealth-to-income ratio of the top 0.1 percent of taxpayers has declined from 6.5 to 3.5 percent. The wealth-to-income ratio of the top 1 percent earners went down from about 4 to around 2 percent. This gives some indication of a change in the composition of the top earner groups in Denmark. Today's top earners are less likely to have substantial wealth than top earners thirty years ago. Unfortunately, there is a lack of international evidence of the wealth of top earners owing to data constraints.

89. While most of the gains in top incomes appear to be due to labour income, in some countries the rise in the top income share is related to capital income, particularly for the richest (top $0.1 \%$ and $0.01 \%$ ). Furthermore, inheritances and gifts tend to be highly concentrated and may contribute to the transmission of income and wealth inequalities. This relies on the idea that inequality in inheritance affects equality of opportunities because of the concentration of wealth. This case is strengthened if the inequality in the wealth distribution is due to relatively unrestrained capital accumulation through generations. Inheritance and gift taxes in particular are therefore seen as a way to reduce inequalities and improve progressivity. On the other hand, critics of inheritance taxes argue that this constitutes double taxation and that it encourages consumption instead of savings for a bequest motive.

90. There is however an ongoing debate about the extent to which inherited accumulated wealth is a source of transmission of inequalities and whether this is rising or not. ${ }^{24}$ In this respect, the decline of "rentier" societies in many OECD countries over the course of the $20^{\text {th }}$ century led to less perpetuation of wealth inequality as the middle class become more spread. On the other hand, it remains unclear what the trend is after the 1970s. It is possible that the increase in housing equity of the middle class, particularly for the baby-boomers, and the rise in house prices, could have led to a growth of housing inheritance. Here again, there is conflicting evidence across countries. ${ }^{25}$ Studies also vary with respect to whether inheritance increases or decreases inequality in the wealth distribution while, on the other hand, inheritance plays a very substantial role in shaping the top end of the wealth distribution. According to a review of the literature from Karagiannaki (2011), some studies suggest that inheritance can be wealth-equalising

24. Some studies argue that as much as two-thirds of US net worth is due to inheritances (Kotlikoff and Summers, 1988) while others have estimated the figure to as low as 20\% (Modigliani, 1988), or to a very wide interval ranging from 20 to 50\% (Wolff and Gitelman, 2011). Estimates from other countries also vary between the range of 10-19.5 per cent for Sweden (Klevmarken, 2006) and between 10 to15\% or 20$30 \%$ if looking at inheritance households only for the UK (Karaginannaki, 2011b), and around 35\% in France (Kessler and Masson, 1989).

The Great Depression has been documented to have led to a decline in wealth inequality between the 1920s and the 1970s (Kopczuk and Saez, 2004). On the other hand, evidence differs by country for recent decades. In the UK, the rise in house prices appear to have led to an increase in the size of inheritance but also to a small increase in the number of housing estates (Karaginannaki, 2011b). Evidence from the US indicates however that although the average value of inheritances increased, wealth transfers as a proportion of current net worth fell between 1989 and 2007 (Wolff and Gittleman, 2011). 
reflecting the role of imperfect correlation of spousal backgrounds (Laitner, 1979), the tendency of parents to either distribute their estates equally among children (Stiglitz, 1969) or to leave more to less well-off children (Becker and Tomes, 1979). On the other hand, other studies show that voluntary bequests have a disequalising effect with respect to the distribution of wealth (De Nardi, 2004).

91. The taxation of wealth can be based on three approaches: taxing the base (property taxes, net worth), the asset transfer (inheritances and gifts, land and capital transfers) or the increase in value of assets and real estate. These are discussed, in turn, below.

\section{Property taxes}

92. Housing taxation varies across countries, although a common feature is that owner-occupied housing is often treated favourably relative to other forms of investment, notably through reduced tax rates or tax exemptions for imputed rental income. Imputed rental income on principal homes is subject to income tax, only in a few countries: Belgium, Iceland, Luxembourg, the Netherlands, Poland, Slovenia, Switzerland and Turkey; but the rental value is often under-estimated. At the same time, mortgage interest payments can be deducted from the personal income tax base in about half of OECD countries and a few countries have tax credits for owner occupancy. In most of the OECD countries realised capital gains from the sale of principal homes are tax-exempt (but not for secondary homes) or the taxation of gains is deferred or exempt if reinvested in another principal home (Andrews et al., 2011).

93. By contrast, most countries levy recurrent taxes on immovable land and buildings. In most countries the magnitude of these taxes appears to be relatively low, as reflected in their low revenue shares and they represent a small percentage of overall taxation (Figure 28). However, in several countries the administrative property value for tax purpose lags well behind the market value.

Figure 28. Taxes on property as a percentage of total taxation

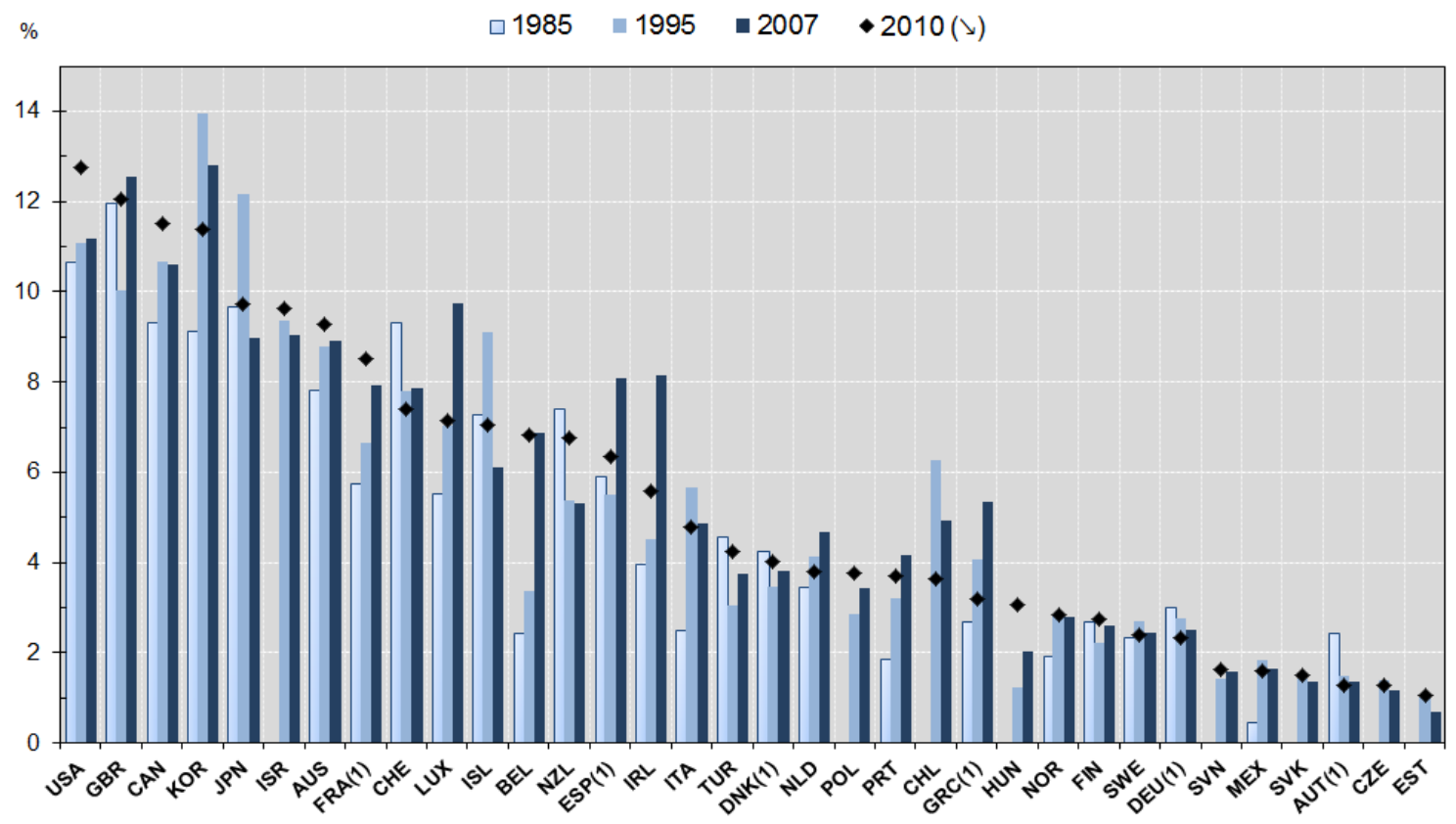

Note: The total tax revenue has been reduced by the amount of any capital transfer that represents uncollected taxes. The capital transfer has been allocated between tax headings in proportion to the reported tax revenue, except for Austria where it has been allocated to the social security contributions heading. * Information on data for Israel: http://dx.doi.org/10.1787/888932315602..

Source: OECD Revenue Statistics. 
94. While taxes on immovable property are relatively low across the OECD, very few countries have implemented increases since the economic downturn. Exceptions include Greece and Italy which have implemented significant increases in the taxation of property. The UK has also increased taxation of high value properties (over 2 million pounds in value purchased by certain corporate bodies) and the introduction of an additional annual charge for such properties from April 2013, as well as a new tax band rate at $7 \%$ for high value properties. Ireland and Slovakia have also announced increases in recurrent taxation of residential property, while Austria has increased taxation of profits from immovable property transactions and the Czech Republic and Portugal have increased transaction taxes on real property.

\section{Net Wealth tax}

95. Net wealth is only taxed in a few OECD countries and often only on assets over a certain amount. Countries having and collecting a wealth tax include: France, Norway, the Netherlands, Spain and Switzerland (at the cantonal level). Spain temporarily abolished the wealth tax between 2008 and 2011, when it was reintroduced as part of measures to reduce the budget deficit. Wealth taxes have for long been considered outdated given the belief that large wealth disparities have disappeared during the $20^{\text {th }}$ century. However, since the recent crisis there have been renewed discussions about reintroducing or increasing wealth taxes. While the debate continues in certain countries, recurrent taxes on wealth have increased in France (permanently) and Spain (temporarily).

Table 6. Wealth tax in OECD countries

\begin{tabular}{|c|c|}
\hline 1985 & 2012 \\
\hline $\begin{array}{ll}\text { - } & \text { Austria } \\
\text { - } & \text { Denmark } \\
\text { - } & \text { Finland } \\
\text { - } & \text { France } \\
\text { - } & \text { Germany } \\
\text { - } & \text { Iceland } \\
\text { - } & \text { Luxembourg } \\
\text { - } & \text { Netherlands } \\
\text { - } & \text { Norway } \\
\text { - } & \text { Spain } \\
\text { - } & \text { Sweden } \\
\text { - } & \text { Switzerland }\end{array}$ & $\begin{array}{ll}\text { - } & \text { France } \\
\text { - } & \text { Netherlands } \\
\text { - } & \text { Norway } \\
\text { - } & \text { Spain } \\
\text { - } & \text { Switzerland }\end{array}$ \\
\hline
\end{tabular}

Source: OECD, CTPA.

\section{Inheritance and gift taxes}

96. By contrast, levying taxes on gifts and bequests is a common practice in OECD countries, though transfer taxation differs widely across countries. Table 7 summarizes how wealth transfers are taxed in OECD countries. First, a number of countries do not levy any specific tax on bequests or gifts. In two third of the OECD countries, bequest and gift are subject to taxation. A distinction is traditionally made between inheritance tax, which is levied on the recipient of the estate, and estate tax, which is levied on the estate or the donor.

97. A tax on estates is levied in Denmark, the United States and the United Kingdom (the other English speaking countries used to have such a tax implemented). In most countries the tax is levied on the recipient of the estate and the tax rate depends on the relationship with the donor. Some countries have 
different tax bands depending on the degree of kinship with the donor. Tax rates for close relatives (Spouse -or in some cases, civil partner - and sometimes children) may even be zero ${ }^{26}$.

Table 7. Inheritance and gift tax in OECD countries

\begin{tabular}{|c|c|c|}
\hline Estate Tax & Inheritance Tax & No tax on wealth transfers \\
\hline $\begin{array}{ll}\text { - } & \text { United Kingdom } \\
\text { - } & \text { United States } \\
\text { - } & \text { Denmark (S) }\end{array}$ & $\begin{array}{ll}\text { - } & \text { Czech republic (S) (C) } \\
\text { - } & \text { Denmark (S) (C) } \\
\text { - } & \text { Finland } \\
\text { - } & \text { France (S) } \\
\text { - } & \text { Germany } \\
\text { - } & \text { Greece } \\
\text { - } & \text { Hungary (S) (C) } \\
\text { - } & \text { Ireland (S) } \\
\text { - } & \text { Italy }(\mathrm{S}) \\
\text { - } & \text { Japan } \\
\text { - } & \text { Korea } \\
\text { - } & \text { Luxembourg (S) (C) } \\
\text { - } & \text { Norway (S) } \\
\text { - } & \text { Poland } \\
\text { - } & \text { Slovenia (S) (C) } \\
\text { - } & \text { Spain } \\
\text { - } & \text { Switzerland (cantonal) }\end{array}$ & $\begin{array}{ll}\text { - } & \text { Australia } \\
\text { - } & \text { Austria } \\
\text { - } & \text { Esnada } \\
\text { - } & \text { Mexiconia } \\
\text { - } & \text { New Zealand } \\
\text { - } & \text { Portugal } \\
\text { - Slovak Republic } \\
\text { - Sweden }\end{array}$ \\
\hline
\end{tabular}

Note: (S): the spouse - or civil partner in some countries - is tax-exempt. (C): Children are tax-exempt

Source: OECD, CTPA.

98. Inheritance and gift taxes are typically progressive. Even if the bequest or gift is taxed at a flat rate (like in Italy, Ireland or the United Kingdom for instance), the tax free allowance makes the effective tax rate increase with the value of the bequest. In most countries there are several tax bands, and the top marginal tax rate goes up to $45 \%$ in France and 50\% in Japan and Korea. The effective tax rate depends strongly on the tax allowances as well as on the number and size of the brackets. 
Figure 29. Effective tax rate on bequests transmitted to direct descendant

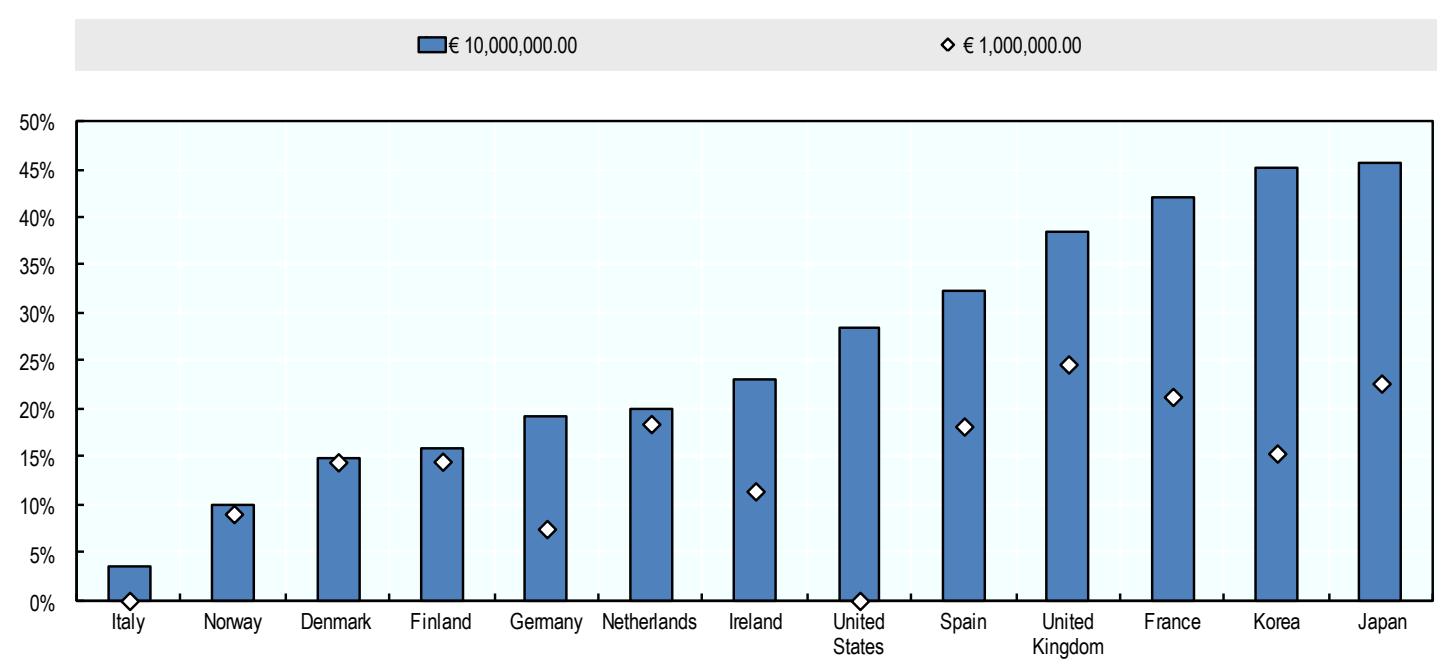

Note: Effective tax rate on the wealth transferred to the donor's child, or in the case of the United Kingdom and the United States, effective tax rate levied on the estate.

Source: OECD calculations

99. Inheritance or gift taxes may be levied only on few tax payers. For instance, the estate tax in the United States affects less than two percent of descendents. In 2012, only estates (including life time gifts) of more than $\$ 5.12$ million were subject to the estate tax. As a result, inheritance and gift contribute only marginally to total tax revenues but are highly progressive. Inheritance and gift tax is generally considered as playing a key role in reducing inequalities and seen as a way to guarantee some form of equality of opportunity. In Spain, the beneficiary has to pay a surcharge if her personal wealth exceeds a given threshold (which depends on the relationship with the decedent).

100. The legitimacy of inheritance and gifts taxes is however widely debated. Some countries, like Australia, Canada, or Sweden have repealed the inheritance tax. Stasavage and Scheve (2010) provide information on the historical evolution of the top marginal inheritance tax rate over the ninetieth and twentieth centuries. Over the recent decades, the top marginal rate has decreased in all countries but France and Germany. Some countries, like Australia, Canada, or Sweden have recently repealed the inheritance tax. Several countries have experienced major changes in how inheritance is taxed. For instance, in Sweden, while the top marginal inheritance tax rate used to be fairly high (above 60\%) in Sweden in the 1970s, inheritance and gifts are no longer taxed nowadays. Since the recent crisis, however, some countries, like the United States and Ireland, have decided to increase the top tax rate levied on large estates.

101. Top inheritance tax rates have been cut in countries where they were very high. The same pattern is observed for the inheritance tax as for the income tax rate in the United Kingdom and the United States. The top marginal inheritance tax rate used to be fairly high (above 60\%) in Sweden before inheritance tax was repealed. An opposite trend is observed in France and Germany; in those countries, the marginal tax rate was relatively low in the 1970s and has increased over the last decades. At the same time, since the economic downturn, Ireland and the U.S. have increased their estate/inheritance taxes. 


\section{Changes in tax policy and top incomes' behaviour}

102. There is currently a debate about raising taxes for top income recipients given their increased share of gross income and the related ability to pay taxes as well as the possibility to increase tax revenues in times of economic recession when resources are scarce. This section reviews theoretical considerations and empirical evidence regarding the sensitivity of top incomes to tax changes, particularly with respect to the different income components. It discusses findings on the possibility to design an appropriate tax rate which takes into account the different impacts on progressivity, efficiency and maximum tax revenue. The analysis provides an overview of the possible implications of increasing certain taxes affecting top incomes.

\subsection{How responsive are top incomes to changes in marginal tax rates on income?}

103. Part of the rationale behind declining tax rates in the past 40 years was based on models of economic principles on how tax rates for top incomes affect growth and investment rates. Economic theory and evidence from previous tax reforms in several countries suggested that changes in tax rates set off behavioural responses affecting taxable income. Lower marginal tax rates were deemed to trigger investments, stimulate labour supply and, hence, increase growth.

104. The concept of elasticity of taxable income with respect to the net of tax rate (ETI) captures all the different behavioural responses triggered by taxation and consequently summarises the changes in the tax base caused by a change in the tax rate. The elasticity of taxable income measures the percentage change in the reported income when the net of tax rate increases by 1 percent (i.e. the top marginal tax rate decreases by 1 percent). The elasticity captures not only labour supply responses but also other responses such as tax evasion or income shifting. As suggested by Piketty et al., (2011) the impact of top tax rates on upper incomes may go through three different channels.

105. First the impact of top tax rates on top incomes might be explained by changes in labour supply, investment and entrepreneurial activity. According to a standard supply-side model proposed by Lindsey (1987) and Feldstein (1995), lower tax rates stimulate the economic activity among top income earners by making work and entrepreneurship more attractive. Lower top marginal tax rates should consequently result in higher economic growth and possibly higher income concentration.

106. Second, top incomes may respond to tax changes through tax avoidance and income sheltering. Tax avoidance can take many forms: substitution of cash compensation with fringe benefits, change in the business organisation in order to shift profits from earnings to capital income and many others. The elasticity of taxable income is higher for high-income individuals who have more possibilities to increase income shifting and tax evasion (Claus et al., 2012; Saez et al., 2012). The tax avoidance elasticity may be considered as a policy choice (Slemrod and Kopczuk, 2002), since it may be reduced by limiting tax avoidance opportunities and improving tax enforcement. However, some tax avoidance opportunities may turn out to be costly to eradicate and some tax loopholes are designed to improve overall efficiency. As pointed out by Saez et al., (2012) the positive externalities produced by income shifting should be accounted for when analysing the welfare impact of a tax change. Under this scenario, most of the surge in top incomes is due primarily to tax avoidance being reduced as a result of decreasing top tax rates. At the same time, opportunities for tax avoidance are progressively reduced with increased tax transparency and co-operation (see OECD's Global Forum on Transparency and Exchange of Information for Tax Purposes). 
107. The third channel put forward by Piketty et al., (2011) is that top tax rates are part of the institutional setting which determines top executives bargaining power ${ }^{27}$. High top marginal tax rates make pay increase less profitable for very well paid executives. The net reward for bargaining for higher pay is all the less profitable as the top marginal rate is high. Lowering tax rates may result in top executives bargaining more aggressively for a pay increase (as they can keep a greater fraction of it), thus increasing top executives bargaining power and consequently their compensation=

108. Early studies in the 1980s found very large estimates of the elasticity of taxable income with respect to changes in tax rates in the United States. Lindsey (1987) finds the elasticity of taxable income in the United States to be around 1.6-1.8 and even provides larger estimates for higher income groups. Other studies suggest that short-term responses to a tax reform are large but there are several methodological issues concerning the estimation of elasticity rates for top incomes (Box 5). The main question is however, whether tax reforms entail permanent changes in reported income or only transitory responses. The use of time series on top income shares from 18 OECD countries between 1960 and the late 2000s suggests that the long-run elasticity of taxable income is around 0.5, meaning that top incomes are quite responsive to tax changes even over a long period of time (Piketty et al., 2011).

109. In line with Slemrod (1996), Gruber and Saez (2002), show that the decrease in tax revenue due to an increase in taxation is mainly driven by avoidance and income sheltering. Using a panel of tax returns over the 1979-1990 period for the United States they find the elasticity of taxable income to be equal to 0.57 for high earners (over $\$ 100,000$ ), 0.11 for those from $\$ 50,000$ to $\$ 100,000$ and 0.18 for those from $\$ 10,000$ to $\$ 50,000$. However, the elasticity of broad income is small for top earners (0.17), suggesting that the real economic response is quite limited; Furthermore, it means that the tax system produces high efficiency costs due to its many avoidance opportunities. Kleven and Schultz (2012), analysing the effects of the 1987 tax reform in Denmark, find small estimates of labour income elasticity (0.05) and of capital income elasticity (0.2). The Danish tax system is characterised by a broad tax base and few avoidance opportunities.

27. This model rests on the assumption that pay is not always equal to marginal product for high earners. A large literature on corporate governance seems to show that this is the case for top executives (see Bebchuk and Fried (2004) for a review). 


\section{Box 5. The taxable income elasticity and the optimal tax rate}

\section{Theoretical framework}

The elasticity of taxable income measures the responsiveness of gross income to a change in tax rate. Formally the elasticity of taxable income is defined as:

$$
e=\frac{1-\tau}{z} \cdot \frac{\delta z}{\delta(1-\tau)}
$$

With $\tau$ being the top marginal tax rate and $z$ pre-tax income. As reflecting the extent of the behavioural response to changing top tax rate, the elasticity of taxable income may be used to compute the optimal tax rate, i.e. the tax rate maximising tax revenues. An increase in top tax rate affects the government revenue through two channels. There is first a mechanical increase in tax revenue as the tax rate is higher. But the increase in tax rate sets off a behavioural response that reduces the reported income. The optimal tax rate maximises the mechanical effect under the constraint of the behavioural effect. For the top bracket above a threshold $\bar{z}$, the revenue-maximising tax rate is admittedly (See Saez et al., (2012) for detailed calculation) given by:

$$
\tau^{*}=\frac{1}{1+a \cdot e}
$$

With $e$ being the elasticity of taxable income and $a$ the Pareto coefficient which is equal to $\frac{z^{m}}{z^{m}-\bar{z}}$ with $\bar{z}$ being the threshold of the top bracket and $z^{m}$ the average income of individuals in the top bracket. The optimal tax rate is negatively related to the taxable income elasticity. The larger the behavioural responses to taxation, the smaller the revenue-maximising tax rate. This optimal tax rate assumes that the government does not value any additional consumption of high incomes. In practice, this assumption should hold for very high incomes but top PIT rates are levied in some OECD countries at relatively low income levels, making the assumption too strong in these countries.

\section{Empirical analyses}

Estimating empirically the taxable income elasticity is not straightforward and is subject to much debate, especially because it determines the subsequent optimal tax rate. Saez et al., (2012) review the different empirical strategies that have been used to deal with identification issues. The first way to estimate the taxable elasticity is to compare reported income before and after a reform affecting tax rates. Looking at the share of total income flowing to top earners over time is a good measure of the evolution of top incomes relative to the rest of the population.

A common way to estimate the elasticity using time-series data is to run a time-series regression like $\log p_{t}=e$. $\log \left(1-\tau_{t}\right)+\varepsilon_{t}$ with $p_{t}$ being for instance the top 1 percent income share at time $t$. But any variation in the top 1 percent income share that is unrelated to tax changes would bias the estimate. The increase in income concentration in English-speaking countries is admittedly not solely driven by the decrease in top marginal tax rate. Some controls may be added to account for variation unrelated to changes in tax rates. The main issue is to find relevant controls, since the factors driving top income shares are not clearly identified. Adding time trends might be an option and multicountry analysis is a good way to do so without destroying identification, provided cross-country differences are accounted for by relevant controls. Roine et al., (2009) and Atkinson and Leigh (2010) conduct analyses using this methodology.

A relatively new way to estimate the elasticity of taxable income is to use micro-based regressions following difference-in-difference models which compare changes in reported income of a treated group (that is impacted by the tax reform) with changes of a control group (which is not affected by the tax reform). The bulk of the literature uses panel data even though making use of repeated cross-sectional data have some advantages compared to panel data (this point is extensively detailed by Saez et al., (2012)). The main limitation of this approach is that it does not allow for analysing whether short-term responses persist over time. The increase in top income since the mid-1990s may be due partly to the decrease in tax rates in the 1980s. Piketty (2001) shows that progressive income tax impacts capital accumulation which implies that capital income are driven also by past tax rates. Atkinson and Leigh (2010) use a model where capital income depends on past tax rates on the grounds that the impact of taxation on capital income also goes through its impact on accumulation. 
110. The main policy lesson from these studies is that the elasticity of taxable income is a parameter that can be influenced by tax design. Before increasing top tax rates policy makers need to make sure to limit avoidance opportunities as much as possible, so as to reduce the cost of increasing taxes. At the same time, in a highly globalised world, top earners can more easily change their country of residence, or if they work in different countries can receive the salary in the lowest-taxed country. This limits the capacity of national tax policies to improve tax design and has triggered discussion on strengthening of international tax cooperation. ${ }^{28}$

111. IMF (2013) compares actual top marginal income tax rates to revenue-maximising tax rates for a number of OECD countries. Using different values for the elasticity of taxable income, they estimate the range of revenue-maximising tax rates for a number of OECD countries ${ }^{29}$. For most countries, the revenuemaximising tax rate is estimated to lie between 45 and 70 percent. The actual top tax rates lie within, but at the lower-bound estimated range in most countries, making it difficult to predict what would be the impact on tax revenues of increasing the current top tax rate. The current top tax rate stands at the upper end of the estimated range only in Sweden, so that an increase in the top tax rate is estimated to result in a decrease in tax revenues. In contrast, it is significantly beyond the range in New Zealand, Norway, Switzerland and the United States, and at the lower end of the range in Australia, Canada, Germany, Portugal and Spain suggesting that in these countries top marginal tax rate could be increased without translating into a decrease in tax revenues. At the same time, effects of increased top tax rates on overall inequality are deemed to be rather modest. ${ }^{30}$

\subsection{Is there an optimal tax rate for top incomes: efficiency, equity and revenue trade-offs}

112. The progressivity of the tax system is traditionally justified by equity motives. Arguably, the tax structure should depend on individual's ability to pay (Ramsey, 1927; Mirrlees, 1971), with higher taxation of those with higher ability to pay in order to redistribute to those with low ability to pay. In some countries top income earners have a substantial share of total income and therefore pay an important fraction of the personal income tax. In 2006, the top 1 percent of taxpayers ${ }^{31}$ paid next to 40 percent of personal income taxes in the United States (Murphy and Brian 2009), and about 23\% in the United Kingdom (HMRC, 2012). Many OECD countries display a decreasing pattern of tax progressivity across income levels. In some countries, the tax system becomes regressive when the social security contributions (SSC) ceiling has been reached (Paturot et al., 2013). For instance, Landais et al., (2011) show that the French tax system is regressive at the top of the income distribution, partly because the SSC ceiling has been reached but also because of refundable tax credits that substantially lower the income tax burden for the richest. There is some scope for increasing progressivity at top income levels.

113. It is often argued that taxing disproportionally top earners may trigger behavioural responses and thereby produce large deadweight losses (see above). Supply side economics emphasise that lower top

28. The normative case for stronger international tax co-operation and an international tax organisation is discussed for instance in Dietsch and Rixen (2012).

They set the elasticity of taxable income between 0.25 and 0.5 and use estimate of the Pareto coefficient (which measures the distribution of income within the upper income group) from the World Top Incomes Database.

A return of top tax rates on the top $1 \%$ earners to their lavels in the 1980 s is estimated to reduce the Gini coefficient by less than one point (IMF 2013).

31. The top 1 percent of taxpayers is obviously an even smaller group that the top 1 percent of the population, since not everyone pays personal income tax. 
marginal tax rates should stimulate economic growth and employment. Cross-country studies have found some impact of taxes on employment at the macro level: a ten-percentage point reduction of the tax wedge in an average OECD country would increase the employment rate by 3.7 percentage points (Johansson et al, 2008). This is confirmed by studies at the individual level on the negative effect of high tax wedges for second earners and women. However, these results hold for labour income on average, not necessarily for top incomes.

114. Moreover, very high top marginal tax rates may be suboptimal for the government, since lowering the tax rate may increase total tax revenues. A tax increase has two impacts on the tax revenues. First, as taxpayers face a higher tax rate on their income, there is a "mechanical" increase in tax revenues. This increase is however mitigated by behavioural responses triggered by the increased tax rate that reduce the taxable income. The total change in tax revenues is given by the sum of the two effects. The so-called Laffer curve (Wanninski, 1978), which posits an inverted U-shape relationship between tax rates and government revenues, illustrates the trade-off between these two effects. The optimal tax rate maximises the mechanical effect under the constraint of the behavioural effect and is such that any tax reform - an increase or a cut in rates of taxation - would result into a drop in tax revenues. The revenue-maximising tax rate depends mainly on the behavioural responses, the magnitude of which is measured by the elasticity of taxable income.

115. While the significant reduction in top marginal tax rates that occurred in many OECD countries over the past decades was mainly motivated by the reasoning outlined above, recent developments in optimal taxation theory suggest that the elasticity of taxable income - and thus the subsequent optimal tax rate - depends chiefly on the features of the tax system such as tax sheltering opportunities, since the efficiency cost of taxation is largely due to income sheltering. Gruber and Saez (2002) find the elasticity of taxable income to be equal to 0.57 and the elasticity of broad income to be 0.17 . Under the current tax system, the optimal tax rate given by the classic formula (assuming the Pareto coefficient to be equal to 1.5 - see Box 5) is 53\%, while it would be next to $80 \%$, were all the avoidance opportunities eliminated (i.e. the elasticity of taxable income be equal to the broad income elasticity). Thus, the efficiency cost of taxation depends not only on the real economic responses but also on the features of the tax system, especially for top earners. The magnitude of the optimal tax rate depends primarily on the value of the elasticity of taxable income, which is difficult to precisely estimate. Furthermore, the empirical estimates underestimate the role of geographical mobility of high-income earners. Therefore, one must be careful when drawing policy implications from the empirical literature on optimal taxation.

116. Another rationale for higher top marginal tax rates is that, under some circumstances, large income inequality may harm long-run economic efficiency, making the traditional trade-off between equity and efficiency less relevant. Very large income inequality may generate inequality traps $^{32}$ (Bourguignon et al., 2007), resulting into weaker equality of opportunity for the next generation and consequently lessening future overall economic efficiency. Reducing income inequality may therefore improve long-run economic efficiency. Furthermore, if top wage executives' pay exceeds their marginal productivity, then high tax rates may prevent rent-seeking behaviour and thereby improve both equity and efficiency (Piketty et al., 2011).

32. Inequality traps describe "persistent differences in power, wealth and status between socio-economic groups, that are sustained over time by economic, political and socio-cultural mechanisms and institutions", Bourguignon, Ferreira and Walton (2007) p.236. 


\subsection{Policy trade-offs between different forms of taxation}

117. For all forms of taxation, there are different trade-off issues between equity and efficiency considerations. This section presents the possible implications of raising different taxes on the behaviour of top income earners, on redistribution and on the economy.

\section{Personal income taxes}

118. Raising top marginal tax rates for personal income taxes is often advocated as an avenue to increase the progressivity of the tax system but may also have an impact on labour supply decisions (hours of work, the intensity of work, career choices), productivity and the shift between different types of income, as mentioned above. Changes in marginal tax rates of labour have both income and substitution effects which make the overall impact on labour supply uncertain. On the one hand, a lower marginal tax rate should induce individuals to work more as work becomes more attractive but it will also increase their after-tax income, resulting in the opposite effect. The overall impact is likely to depend on the responsiveness of different groups at different points of the income distribution.

119. Evidence from previous tax reforms in several countries suggests substantial short-run responses of taxable income to the changes in marginal tax rates among the high income taxpayers. Going beyond the substitution and income effect, Kim (2012) uses a model whereby lower tax rates increase the benefits of human capital accumulation and finds that the reduction of the top marginal tax rate from $70 \%$ to $40 \%$ in the US can account for nearly two-thirds of the increase in top income inequality and $68.4 \%$ of the increase in the top 1\% income share between 1980 and 2010. Another study for five English-speaking countries estimates that a 1 percentage point cut in the marginal wage tax rate paid by the top percentile group would lead to a 1.1-1.8 percent increase in the top percentile group share (Atkinson and Leigh, 2010).

120. At the same time, progressivity and redistributive effects depend not only on top statutory rates but also on allowances, deductions, exemptions and credits. These tax allowances might reduce considerably the effective burden faced by many households. In addition to the distorting impact on behaviour, these tax provisions imply a reduction in horizontal equity if not all taxpayers are able to benefit from these allowances to the same degree. Moreover, because the value of the tax allowances are increasing in the PIT rate, the richer gain more than the households that face a lower marginal tax rate, which then violates the vertical equity tax principle (Johansson et al., 2008). On the other hand, certain benefits such as child benefits increase progressivity (especially at low income levels) for households with children as these benefits are typically phased out when income increases. Reducing tax allowances and exemptions for top incomes can make it possible to increase average tax rates on top income recipients without also raising their marginal rate, thus enable more redistribution, with less unwanted distortion of labour supply and "effort" (OECD, 2011a).

\section{Capital income taxes}

121. Corporate income taxes are often considered the most harmful for growth as they discourage investment in capital and productivity improvements. Based on economic theory, there has long been the belief that such capital tax rates should be zero in the long-run (Judd, 1985; Chamley, 1986). This logic has been challenged when there are market imperfections such as borrowing constraints (Aiyagari, 1994, 1995), private information leading to imperfections in insurance markets (Golosov, Kocherlakota, and Tsyvinski, 2003) or when there are labour income taxes on human capital. In addition, the literature on the effects of taxation of capital income concludes that the behavioural response is small (Attanasio and Wakefield, 2010). On the other hand, there is an argument that, because the tax distortion of savings compounds over time, income from capital should not be taxed. This argument holds even if the behavioural effect is small, provided it is not actually zero. Banks and Diamond (2010) analyse this 
argument in detail and conclude that it only applies in very restrictive circumstances. They conclude that capital income should be taxed but are agnostic about the appropriate rate.

122. On the other hand, a reduction in the corporate tax rate implies a reduction in the overall tax burden which could mainly be beneficial to higher income earners. Indeed, top income earners typically earn a larger share of capital income than lower income earners and a reduction of the tax burden on capital income might have a regressive distributional impact. In addition, lowering tax rates on capital substantially below the top personal income tax rate can distort the tax system as high-income individuals will attempt to have their income characterized as capital rather than as labour income, for instance by incorporating themselves. These income shifting issues are observed in most countries where the tax burden on capital income deviates from the tax burden on labour income, e.g. some of the Nordic countries since they introduced a "dual" taxation system in the 1990s. The fact that social security contributions are often levied only on labour income just strengthens the income shifting.

123. Would capital gains taxes be a tool that could effectively redistribute wealth in society, or promote investment in productive sectors other than property? Top earners may benefit from having part of their remuneration as capital gains (rather than ordinary income), and hence at a rate that is generally below their marginal income tax rate. Because there is no obvious "market failure" or externalities argument to justify a tax subsidy in this case, it would seem reasonable to treat remuneration in the form of "carried interest" arrangements ${ }^{33}$ and stock options in the same way as ordinary income. This would ensure that top income recipients pay a higher average effective tax rate and is likely to increase equity.

124. In addition, there are some arguments against exempting capital gains from taxation on efficiency grounds. One consideration is that exempting capital gains from taxation may distort portfolio investment decisions of households in favour of assets generating tax-exempt capital gains, which may give rise to policy concern - in particular, where capital gains assets (assets generating capital gains/losses) are generally more risky than other assets, implying a tax distortion encouraging risk-taking above levels consistent with tax neutrality (OECD, 2006). While low capital gain taxation may be used to reduce or avoid lock-in effects, there are also some arguments about the distortions generated by keeping such taxes at a low level. A low effective capital gains tax rate, compared with the effective tax rate on dividends, may distort corporate distributions policy, encouraging corporations to reinvest profits rather than distribute them. Research from the US suggests that taxing capital gains and dividends as ordinary income would finance a cut in the corporate tax rate from $35 \%$ to about $26 \%$, but this assumed no behavioural response (Altshuler et al., 2011).

125. On the other hand, since the taxation occurs at the time of selling, high capital gains taxes encourage investors to hold rather than sell - thereby avoiding the tax indefinitely. Capital gains tax reductions are often proposed as a policy that will increase saving and investment. The empirical evidence of lock-in effects and large permanent responses to taxation shows that changes in the tax rate or anticipated changes have coincided with large increases in capital gains realizations, but realizations quickly fell back to previous levels (Burman and Randolph, 1994). Besides, the long-run level of output depends on the amount of saving and investment but there is no robust empirical evidence linking capital gains tax reductions on increased saving and investment (Gravelle, 2003).

126. Recently, several countries have put forward such reforms involving an increase in the taxation of capital gains and dividends under the argument of either promoting a more progressive taxation closing the gap between labour income and capital gains taxation- or seeking to increase tax revenue from other sources, while trying to balance keeping capital taxes low to avoid discouraging saving and

33. Carried interest is a feature of the financial arrangements of partnerships. This structure provides the partners or managers a share of an investment fund's profits given as payment for their services. 
investment. In the United States, an increase in the tax rate for qualifying dividends and capital gains (from $15 \%$ to 20\%) was announced in 2013 for tax-payers above a certain income threshold. The UK introduced in 2010 a tax hike from $18 \%$ to $28 \%$ on capital gains for gains above a certain limit while keeping an entrepreneurs relief with both a lower rate and lifetime limit on relief.

\section{Wealth, inheritance and gift taxes}

127. There is currently a renewed interest in wealth taxes as a way to tax the top incomes more and as a possible avenue for tax revenue increases. In principle, net wealth taxes can be used to redistribute income from rich to poor if they are based on total net wealth and have an exemption level that is high enough to exclude the life-cycle savings of all but the wealthy. Though wealth tax typically accounts for a relatively small share of tax revenues, it contributes strongly to overall tax progressivity, as underlined by Piketty and Saez (2006) in the case of France. The economic consequences of net wealth tax are difficult to estimate. The main drawback of net wealth tax is that it may trigger behavioural responses reducing tax revenues. It is often argued that because of wealth tax financial assets are at risk of being moved abroad, which would diminish the domestic base of income tax and consequently tax revenues. These taxes discourage savings of the people to whom they apply, and may encourage people to move their wealth offshore. Some studies suggest that raising wealth taxes is likely to increase tax evasion rather than reduce savings (Seim, 2012). Because wealth taxes tend to be residence-based, wealthy individuals can avoid the tax by relocating. At the same time, Zucman (2008) finds the tax evasion caused by the wealth tax in France to be limited and small compared with the tax revenue generated by this $\operatorname{tax}^{34}$.

128. In practice, net wealth taxes often exempt certain assets, such as pension fund assets, thus distorting the portfolio choice and providing a method of tax avoidance: borrowing money (that will reduce net wealth) to purchase tax exempt assets (Johansson et al., 2008). The implementation of net wealth taxes on the stock of wealth is related to a number of administrative problems, including the difficulties to define a comprehensive tax base, appraise assets and prevent tax evasion (Adam et al., 2011; Brown, 1991). This applies mostly to wealth taxes on the stock rather than on transfers. A wealth tax in this form would tax not only inherited wealth but also wealth representing the individual's accumulated savings from taxed income. To limit avoidance and distortions to the way that wealth is held, as well as for reasons of fairness, the base for such a tax would have to be as comprehensive a measure of wealth as possible but many forms of wealth are difficult or impractical to value.

129. Inheritance taxes affect incentives governing the choice between consuming now and bequeathing but the empirical evidence on the impact of wealth taxes on savings remains mixed. The impact of the distortion of inheritance taxes however depends on the bequest motive. If bequests are accidental or motivated by the joy of giving, the impact of taxes on savings is likely to be nil. If, on the other hand, the bequest motive is altruistic or strategic, the impact on savings will be negative (Cremer and Pestieau, 2003). Both the theoretical motivations and the empirical evidence of bequests remain inconclusive and provide little guidance on what should be the optimal tax rate. For instance, there is little difference in saving behaviour between people with and without children (Hurd, 1989; Kopzuck and Lupton, 2007) and, although there is some altruism, it is likely that bequest motives are heterogeneous and that altruism alone is unlikely to explain the concentration of wealth at the top of the distribution (De Nardi, 2004). Analysis of historical data on gifts shows that taxes significantly raise the cost of lifetime gifts, and that such gifts are responsive to tax rates and exemptions but they appear to be significantly underutilized as a tax planning (Joulfaian and McGarry, 2004; Joulfaian, 2004). Additionally, taxation of inheritance may be used to reduce the fact that the receipt of an inheritance may also impact on individuals' willingness to work, the so-called Carnegie effect (Brown et al., 2010). At the same time, such wealth and inheritance taxes are believed to be less distortive and generate fewer disincentives than other

34. According to his estimates, tax evasion amounted to $10 \%$ of the revenues generated by the wealth tax. 
taxes, especially because their design can be made more neutral with respect to financial decisions and lock-in effects.

\section{Property taxes}

130. Raising taxes on property (recurrent taxes on land and buildings) is often believed to be part of tax reforms that are neutral or growth-oriented while at the same time might contribute to an increase of progressivity and tax revenues. Residential property is generally taxed at lower effective rates than other categories of consumption and other forms of capital income in most OECD countries. In particular, there are tax credits on mortgages and in several countries, and there is a recent debate about the abolition of such tax credits.

131. Recurrent taxes on land and buildings a priori do not affect the decisions of economic agents to supply labour and to invest to the same extent as other taxes. Raising taxes on immovable property could improve economic efficiency and growth by reducing the allocation of capital into housing from other sectors. They could contribute to the usage of underdeveloped land and because most OECD countries provide various tax preferences for owner-occupied housing (such as deductibility of interest on house loans and exemptions from capital gains tax)may result in a misallocation of capital towards housing, away from other investments. In this situation, the pre-tax rate of return on housing investment is below the pretax rate of return on investment elsewhere in the economy. This implies that increasing recurrent taxes on immovable property will shift some investment out of housing into higher return investments and so increase the rate of growth (Johansson et al., 2008). Such taxes are also more difficult to evade. On the other hand, changes in property taxes, particularly on mortgage tax deductions tend to be highly unpopular politically.

132. Taxes on property transactions may have the benefit of shifting investment out of housing into higher-return activities. However, they have the disadvantage of discouraging housing transactions and thus the reallocation of housing to its most productive use, thus reducing growth (Johansson et al., 2008). For example, property transaction taxes discourage people from buying and selling houses and so discourage them from moving to areas where their labour is in greater demand.

\section{Summary and conclusions}

133. There was a remarkable increase in the share of top income recipients in total pre-tax income over the past three decades in most English-speaking countries, particularly in the United States. In other OECD countries the increase remained more modest, albeit in some Nordic and Southern European countries the rise was also noteworthy. The trend has come to halt during the early phases of the Great Recession, with falls in top incomes. That halt did, however, not undo the surge in top incomes over the past decades and also appeared to be temporary in many countries, as top incomes picked up again and grew faster than the majority of incomes since 2010 (e.g. in Australia, Denmark, Norway, Sweden and the United States). While the surge in top incomes is mainly related to an increase in compensation from wages and salaries, a significant fraction of the very top incomes comes from capital income and this fraction has increased recently in countries like the United States.

134. Several theories have developed to explain the change in top incomes. Common explanations are related to globalisation, skill-biased technological change and the change in compensation practices. Importantly, institutional factors such as the change in taxation may have also contributed and may have driven the change in compensation practices in turn. Indeed, while top tax rates were equal to or above $70 \%$ in half of the countries in the mid-1970s, this rate has been halved in many countries by the end2000s. At the same time, countries have differed in the timing and scales of their tax reductions and the 
extent to which top income shares changed either because of income shifting (leading to more income being reported) or behavioural responses in terms of effort.

135. There is renewed interest in adjusting the amount of tax that top income recipients are subjected to across several OECD countries because the sustained rise in the share of top income recipients in total income is taken as a sign that their "ability to pay" tax may have increased and this has coincided with a period where public finances are tight. Trade-offs must, however, be taken into account when designing comprehensive tax reforms.

136. A most direct way to ensure that top income earners pay a higher share of taxes is to raise marginal tax rates on income as well as other taxes which affect them. While there may be some concerns that such measures may not be as effective as intended with regard to raising tax revenues, some recent analysis suggests that there is still some scope to increase top tax rates to maximise tax revenues (see IMF, 2013). There are, however, several options for tax reforms that increase the average tax rate paid by top income recipients without necessarily raising their marginal rates, such as:

- Abolishing or scaling back a wide range of those tax deductions, credits and exemptions which benefit high income recipients disproportionately;

- Taxing as ordinary income all remuneration, including fringe benefits, carried interest arrangements, and stock options;

- Considering shifting the tax mix towards a greater reliance on recurrent taxes on immovable property;

- Reviewing other forms of wealth taxes such as inheritance taxes;

- Examining ways to harmonise capital and labour income taxation;

- Increasing transparency and international cooperation on tax rules to minimise "treaty shopping" (i.e. when high-income individuals and companies structure their finances to take account of favourable tax provisions in different countries) and tax optimisation;

- Broadening the tax base of the income tax, so as to reduce avoidance opportunities and thereby the elasticity of taxable income;

- Developing policies to improve tax compliance;

- Developing policies to improve transparency and tax compliance, including continued support of the international efforts, led by the OECD, to ensure the automatic exchange of information between tax authorities.

137. The tax policy avenues described above will help ensure that wealthier individuals contribute their part towards more inclusive growth. However, it should not be forgotten that taxes play a lesser role for overall redistribution and for promoting opportunities for those at the lower end of the distribution, compared to transfer policies and other social policies, as well as labour market and education policies. In many OECD countries, the rise in overall inequality has also been driven by low-income households falling behind in relative and, sometimes, in real terms. In order to tackle the increase of overall inequality, a comprehensive policy strategy and policy mix of these policies to promote equality of opportunities is needed. 
DELSA/ELSA/WD/SEM(2014)5

\section{REFERENCES}

Aaberge, R., and A.B. Atkinson (2010), "Top Incomes in Norway", in A.B Atkinson and T. Piketty (eds.), Top Incomes: A Global Perspective, Oxford University Press, Oxford.

Adam, S., T. Besley, R. Blundell, S. Bond, R. Chote, M. Gammie, P. Johnson, G. Myles and J. Poterba (2011), "Taxes on Wealth Transfers", in Tax by Design. The Mirrlees Review, Oxford University Press, chapter 14, 347-67.

Altshuler, R., Harris, B.H. and E. Toder (2011), "Capital Income Taxation and Progressivity in a Global Economy”, Departmental Working Papers 201122, Rutgers University, Department of Economics

Aiyagari, S. Rao. (1995). "Optimal Capital Income Taxation with Incomplete Markets, Borrowing Constraints, and Constant Discounting," Journal of Political Economy, University of Chicago Press, vol. 103(6), pages 1158-75, December.

Aiyagari, S Rao (1994) "Uninsured Idiosyncratic Risk and Aggregate Saving," The Quarterly Journal of Economics, MIT Press, vol. 109(3), pages 659-84, August.

Alvaredo, F. (2010) "A note on the relationship between top income share and the Gini coefficient", Economics Letters.

Alvaredo, F., A.B. Atkinson, T. Piketty, E. Saez (2012), The World Top Incomes Database, http://gmond.parisschoolofeconomics.eu/topincomes, 06/062013.

Andrews, D., A. Caldera Sanchez and A. Johansson (2011), "Housing market and structural policies in OECD countries" OECD No. 836 Economics Department Working Papers,

Arulampalam, W., M. Devereux, and Maffini, G. (2012). "The direct incidence of corporate income tax on wages," European Economic Review, Elsevier, vol. 56(6), pages 1038-1054.

Atkinson, A.B. (2008), The Changing Distribution of Earnings in OECD countries, Oxford University press, Oxford.

Atkinson, A. B., and A. Leigh (2010), "The Distribution of Top Incomes in Five English-speaking Countries over the Twentieth Century," IZA Discussion Papers 4937, Institute for the Study of Labor (IZA).

Atkinson, A.B., S. Morelli (2011), "Economic Crises and Inequality", Human Development Research Paper.

Atkinson, A.B., T. Piketty and E. Saez (2011), “Top Incomes in the Long Run of History”, Journal of Economic Literature 49(1), pp. 3-71. 
Atkinson, A. B., and A. Leigh (2007), The Distribution of Top Incomes in Australia; in Atkinson, A. B. and Piketty, T. (editors) Top Incomes over the Twentieth Century. A Contrast Between Continental European and English-Speaking Countries, Oxford University Press, chapter 7.

Auten, G., and G. Gee (2009), "Income Mobility in the United States: New evidence from Income Tax Data”, National Tax Journal, 62(2), pp.301-328.

Attanasio, O. and M. Wakefield (2010), 'The effects on consumption and savings of taxing asset returns', in Dimensions of Tax Design: The Mirrlees Review, Oxford: Oxford University Press for the Institute for Fiscal Studies.

Bakija, J., A. Cole and B.T. Heim, (2012), "Jobs and Income Growth of Top Earners and the causes of Changing Income Inequality: Evidence from the U.S. Tax Return Data", Williams College, working paper, April 2012

Bebchuk, L., and J. Fried (2004) Pay without Performance: The Unfulfilled Promise of Executive Compensation, Harvard University Press, Cambridge, Massachusetts.

Becker, G., and N. Tomes (1979), "An Equilibrium Theory of the Distribution of Income and Intergenerational Mobility," Journal of Political Economy, University of Chicago Press, vol. 87(6), pp. 1153-89.

Bourguignon, F., F. Ferreira and M. Walton (2007). "Equity, efficiency and inequality traps: A research agenda", Journal of Economic Inequality, Springer, vol. 5(2), pages 235-256, August.

Björklund, A., J. Roine and D. Waldenstöm (2012), "Intergenerational top income mobility in Sweden: Capitalist dynasties in the land of equal opportunity?", Journal of Public Economics, 96, pp. 474484.

Brown, R. (1991), “A Primer on the Implentation of Wealth Taxes”, Canadian Public Policy / Analyse de Politiques, 17(3), pp. 335-350.

Brown, J., C. Coile, and S. Weisbenner, (2010), "The Effect of Inheritance Receipt on Retirement Decisions" Review of Economics and Statistics, (92) August, 2, pp. 425-434

Brys, B., S. Matthews and J. Owens (2011), "Tax Reform Trends in OECD Countries", OECD Taxation Working Papers, No. 1, OECD Publishing.

Burman, L., and W. Randolph (1994), "Measuring Permanent Responses to Capital-Gains Tax Changes in Panel Data", American Economic Review, vol. 84, no. 4 (September 1994), pp. 794-809.

David Carey and Josette Rabesona (2002) "Tax Ratios on Labour and Capital Income and on Consumption”, OECD Economic Studies No. 35, 2002/2, Paris.

Chamley, Christophe, "Optimal Taxation of Capital Income in General Equilibrium with Infinite Lives," Econometrica, 54, 3 (May 1986), 607-622.

Conyon M., N. Fernandes, M. Ferreira, P. Matos, and K. Murphy (2011), "The Executive Compensation Controversy: A Transatlantic Analysis", USC mimeo.

Cowell, F.A. (1995), Measuring Inequality, Harvester Wheatsheaf: Hemel Hemsptead. 
Cremer, H., and P. Pestieau (2003), "Wealth transfer taxation: a survey," DELTA Working Papers 200320, DELTA (Ecole normale supérieure).

De Nardi, M. (2004), "Wealth Inequality and Intergenerational Links," Review of Economic Studies, Wiley Blackwell, vol. 71, pages 743-768, 07.

Dell, F., T. Piketty, and E. Saez (2005). "Income and Wealth Concentration in Switzerland Over the 20th Century," CEPR Discussion Papers 5090.

Dietsch, P. and Rixen, T. (2012), "Tax Competition and Global Background Justice", in: Journal of Political Philosophy.

Gale, W., and J. Slemrod (2001), "Rethinking the Estate and Gift Tax: Overview," NBER Working Papers 8205, National Bureau of Economic Research, Inc

Gentry, W (2007) , A Review of the Evidence on the Incidence of the Corporate Income Tax, OTA Paper No. 101 (U.S. Department of the Treasury, Office of Tax Analysis, December 2007).

Golosov, M., N. Kocherlakota and A. Tsyvinski (2003). "Optimal Indirect and Capital Taxation," Review of Economic Studies, Wiley Blackwell, vol. 70(3), pages 569-587, 07.

Goolsbee, A. (2000), "What Happens When you Tax the Rich? Evidence from Executive Compensation", Journal of Political Economy 108(2):352-78.

Gordon, R., and J. Slemrod (2000), "Are 'Real' Responses to Taxes Simply Income Shifting between Corporate and Personal Tax Bases?" in J. Slemrod (ed.), Does Atlas Shrug? The Economic Consequences of Taxing the Rich, Harvard University Press

Gravelle Capital Income Tax Revisions and EffectiveTax Rates, CRS Report RL32099

Gruber, J., and E. Saez (2002) "The Elasticity of Taxable Income: Evidence and Implications." Journal of Public Economics 84(1): 1-32.

HMRC (2012), Income Tax Liabilities Statistics, April 2012.

Hoeller, P. (2012), "Less Income Inequality and More Growth - Are they Compatible? Part 4. Top Incomes", OECD Economics Department Working Papers, No. 927, OECD Publishing.

IMF (2013), Fiscal monitor October 2013: Taxing Times. Washington, D.C.

Michael D. Hurd, 1989. "Savings and Bequests," NBER Working Papers 1826, National Bureau of Economic Research, Inc.

Hussain, M., J. Bonke, M. Munk (2011), "Intergenerational Income Mobility- Top Incomes and assortative mating in Denmark", Working Paper from Department of Political Science 2011:2, Aalborg University.

Johansson, A., C. Heady, J. Arnold, B. Brys and L. Vartai,( 2008) "Tax And Economic Growth Economics", Department Working Paper NO.620 ECO/WKP(2008)28

Joulfaian, David, 2004. "Gift taxes and lifetime transfers: time series evidence," Journal of Public Economics, Elsevier, vol. 88(9-10), pages 1917-1929, August. 
Joulfaian, D., and K. McGarry (2004), "Estate Gift Tax Incentives and Inter Vivos Giving" National Tax Journal, Vol. 57, No. 2, Part 2, pp. 429-444.

Judd, K. L. (1985), "Redistributive Taxation in a Simple Perfect Foresight Model," Journal of Public Economics, 28, pp. 59-83.

Karagiannaki, E. (2011a), Recent trends in the size and the distribution of inherited wealth in the UK, Paper No' CASE/146 June 2011

Karagiannaki, E. (2011b) "The impact of inheritance on the distribution of wealth: Evidence from the UK”, June 2011 Paper No' CASE/148

Kessler, D. and A. Masson (1989), "Bequest and Wealth Accumulation: Are Some Pieces of the Puzzle Missing?”, Journal of Economic Perspectives, 3, pp. 141-152.

Kim, J. (2012) “The Effect of the Top Marginal Tax Rate on Top Income Inequality”, Stanford University, unpublished

Klevmarken, N. A. (2006), “The Distribution of Wealth in Sweden: Trends and Driving factors", Working Paper Series 2006:4, Uppsala University, Department of Economics.

Kleven, H., and A. Schultz (2012), "Estimating Taxable Income Responses using Danish Tax Reforms", Paper No' PEP 13.

Kopczuck, W., and E. Saez (2004) "Top Wealth Shares in the United states, 1916-2000: Evidence from Estate Tax returns", National Tax Journal 57(2):445-487.

Kopczuk, W. \& J. P. Lupton (2007), "To Leave or Not to Leave: The Distribution of Bequest Motives", Review of Economic Studies, vol. 74(1), pp. 207-235.

Kotlikoff, L. and L. Summers (1988) "The Contribution of Intergenerational Transfers to Total Wealth: A Reply," NBER Working Papers 1827, National Bureau of Economic Research, Inc.

Landais, C., T. Piketty, E. Saez (2011), Pour une révolution fiscale, un impôt sur le revenu pour le XXI ème siècle, Le Seuil/République des idées.

Laitner, John, 1979. "Household Bequests, Perfect Expectations, and the National Distribution of Wealth," Econometrica, Econometric Society, vol. 47(5), pages 1175-93, September.

Leigh, A (2007), "How closely do top income shares track other measures of inequality?", The Economic Journal, 2007.

Leigh, A (2009), "Top Incomes", in W. Salverda, B. Nolan and T. Smeeding (eds.) The Oxford Handbook of Economic Inequality, Oxford University Press, Oxford

Lindsey, L. (1987) "Individual Taxpayer Response to Tax Cuts: 1982-1984, with Implications for the Revenue Maximizing Tax Rate," Journal of Public Economics 33, 173-206

Matthews, S. (2011), "Trends in Top Incomes and their Tax Policy Implications", OECD Taxation Working Papers, No. 4, OECD Publishing. 
Modigliani, F. (1988a), 'Measuring the Contribution of Intergenerational Transfers to Total Wealth: Conceptual Issues and Empirical Findings.' In Kessler, Denis, and Andre Masson, eds., Modelling the Accumulation and Distribution of Wealth. Oxford: Clarendon Press, 21-52.

Moore, J.C., L.L. Stinson and E.J. Welniak (2000), "Income measurement Error: A Review”, Journal of Official Statistics, 16(4): 331-362

Mudry, K., and J. Bryan (2009). “Individual Income Tax Rates and Shares, 2006.” IRS Statistics of Income Bulletin, (Winter), pp. 5-45.

OECD (2006), "Taxation of Capital Gains of Individuals", Tax Policy Study No. 16, OECD Publishing, Paris.

OECD (2008), “Reforming Corporate Income Tax”, Policy Brief July 2008, OECD, Paris.

OECD (2011a), Divided we Stand: Why Inequality Keeps Rising, OECD Publishing, Paris.

OECD (2011b), Taxation of Widely-Held Dividend Income, Interest Income, and Capital Gains Earned by Individuals in OECD Countries, CTPA/CFA/WP2(2011)28, Document presented at the Working Party No2 of the Committee on Fiscal Affairs, 15-17 November 2011

OECD (2012a), “Taxation of Dividend, Interest and Capital Gain Income”, CTPA/CFA/WP2(2012)20

OECD (2012b), Taxing Wages 2011. Special Feature: Trends in personal income tax and employee social security contribution schedules, OECD Publishing, Paris.

OECD (2013a), Tax Policy Roundtable, CTPA/CFA(2013)1, presented at the OECD Committee on Fiscal Affairs at their 84th Session on 22-23 January 2013.

OECD (2013b), Addressing Base Erosion and Profit Shifting, OECD Publishing, Paris.

Parker, J., and A. Vissing-Jorgensen (2010), "The Increase in Income Cyclicality of High-Income Households and its Relation to the Rise in Top Income Share", NBER Working Paper, No. 16577, Cambridge, MA.

Paturot, D., K. Mellbye and B. Brys (2013), "Average Personal Income Tax Rate and Tax Wedge Progression in OECD Countries", OECD Taxation Working Papers, No. 15, OECD Publishing

Philippon T., and A. Reshef (2009), "Wages and human Capital in The U.S. Financial Industry: 19092006”, NBER Working Paper No. 14644.

Piketty, T. (2001), Les hauts revenus en France au XXe siècle: Inégalités et redistributions 1901-1998. Paris: Grasset.

Piketty, T. (2003), “Income Inequality in France, 1901-1998.” Journal of Political Economy, 111(5): $1004-42$.

Piketty, T., and E. Saez (2003), "Income Inequality in the United States", The Quarterly Journal of Economics, 118(1): 1-39.

Piketty, T., and E. Saez (2006), "How Progressive is the U.S. Federal Tax System? A historical and International Perspective", Journal of Economic perspectives, 21(1): 3-24. 
Piketty, T. and E. Saez (2007), "Income and Wage Inequality in the United States, 1913-2002", in A.B. Atkinson and T. Piketty (eds.), Top Incomes over the Twentieth Century: A Contrast between Continental European and English-Speaking Countries, Oxford University Press, Oxford.

Piketty, T., G. Postel-Vinay and J.-L. Rosenthal (2006) "Wealth Concentration in a Developing economy: Paris and France 1807-1994, American economic Review 96(1): 236-256.

Piketty, T. (2011) “On the Long run Evolution of Inheritance: France 1820-1950”, The Quarterly Journal of Economics 126, 1071-1131.

Piketty, T., E. Saez and S. Stancheva (2011) "Optimal Taxation of Top Labor Incomes: A Tale of Three Elasticities” NBER Working Paper No. 17616, November 2011, Revised March 2013

Roine, J., J. Vlachos, and D. Waldenström (2009), "The Long-Run determinants of inequality: What can We Learn from top Income Data?” Journal of public Economics, 93(7-8): 974-88.

Roine J., and D. Waldenström (2009), "Wealth Concentration over the Path of Development: Sweden, 1873-2006".

Rosen, S., "The Economics of Superstars", American Economic Review, 71 (5), pp. 845-858.

Saez, E., and M. Veall (2005), "The Evolution of High Incomes in Northern America: Lessons from Canadian Evidence.” American Economic Review, 95(3), pp. 831-49.

Saez, E. (2012), "Striking it Richer: The Evolution of Top Incomes in the United States"

Saez, E. (2013), "Striking it Richer: The Evolution of Top Incomes in the United States" (Updated with 2012 preliminary estimates), http://elsa.berkeley.edu/users/saez/saez-UStopincomes-2012.pdf

Saez, E, J. Slemrod, and S. Giertz (2012) "The elasticity of taxable income with respect to marginal tax rates: critical review", Journal of Economic Literature, 50(1): 3-50.

Scheve, K., and D. Stasavage (2012) "Democracy, War, and Wealth: Lessons from Two Centuries of Inheritance Taxation", American Political Science Review, 106.

Seim, D. (2012), "Smart Enough to Evade? On the Incidence of a Wealth Tax”, November 2012. mimeo.

Slemrod, J. (1996), "High-Income Families and the Tax Changes of the 1980s: The Anatomy of a Behavioral Response.", in M. Feldstein and J. M. Poterba (eds.), Empirical foundations of Households Taxation, University of Chicago Press, Chicago and London.

Slemrod, J. and W. Kopczuk (2002), "The Optimal Elasticity of Taxable Income", Journal of Public Economics 84(1):91-112.

Solard, J. (2010) "Les très hauts revenus: des différences de plus en plus marquées entre 2004 et 2007", Les revenus et le patrimoine des ménages - Insee Références - Édition 2010.

Stiglitz, J. E. (1969), "Distribution of Income and Wealth among Individuals", Econometrica, Vol. 37, No.3, pp. 382-397

Wanninski, J. (1978), “Taxes, revenues, and the 'Laffer curve' ”, The Public Interest. 
Wolff, E. and M. Gittleman (2011) "Inheritances and the Distribution of Wealth or Whatever Happened to the Great Inheritance Boom? Results from the SCF and PSID”, NBER Working Paper No. 16840

Zucman, G. (2008) Les hauts patrimoines fuient-ils l'ISF ? Une estimation sur la période 1995-2006, mimeo.

\section{References for the data:}

Aaberge, Rolf and Atkinson, Anthony B. (2010). Top Incomes in Norway; in Atkinson, A. B. and Piketty, T. (editors) Top Incomes: A Global Perspective, Oxford University Press, chapter 9.

Alvaredo, Facundo (2010). Top Incomes and Earnings in Portugal 1936-2005; in Atkinson, A. B. and Piketty, T. (editors) Top Incomes: A Global Perspective, Oxford University Press, 2010, chapter 11.

Alvaredo, Facundo and Pisano, Elena (2010). Top Incomes in Italy 1974-2004; in Atkinson, A. B. and Piketty, T. (editors) Top Incomes: A Global Perspective, Oxford University Press, chapter 12. Series updated by the same authors.

Alvaredo, Facundo and Saez, Emmanuel (2010). Income and Wealth Concentration in Spain in a Historical and Fiscal Perspective; in Atkinson, B. and Piketty, T. (editors) Top Incomes: A Global Perspective, Oxford University Press, chapter 10.

Atkinson, Anthony B. (2007). The Distribution of Top Incomes in the United Kingdom 1908-2000; in Atkinson, A. B. and Piketty, T. (editors) Top Incomes over the Twentieth Century. A Contrast Between Continental European and English-Speaking Countries, Oxford University Press, chapter 4.

Atkinson, Anthony B. and Leigh, Andrew (2007). The Distribution of Top Incomes in New Zealand; in Atkinson, A. B. and Piketty, T. (editors) Top Incomes over the Twentieth Century. A Contrast Between Continental European and English-Speaking Countries, Oxford University Press, chapter 8.

Atkinson, Anthony B. and Søgaard, Jakob (2013). The long-run history of income inequality in Denmark: Top incomes from 1870 to 2010. EPRU Working Paper Series 2013-01. pdf.

Dell, Fabien (2007). Top Incomes in Germany Throughout the Twentieth Century 1891-1998; in Atkinson, A. B. and Piketty, T. (editors) Top Incomes over the Twentieth Century. A Contrast Between Continental European and English-Speaking Countries, Oxford University Press, chapter 9.

Foellmi, Reto and Martínez, Isabel (2012). Volatile Top Income Shares in Switzerland? Reassessing the Evolution between 1981 and 2008. University of St. Gallen, Department of Economics Discussion Paper 2012-27. pdf.

Jäntti, Markus; Riihelä, Marja; Sullström, Risto and Tuomala, Matti (2010). Trends in Top Income Shares in Finland; in Atkinson, A. B. and Piketty, T. (editors) Top Incomes: A Global Perspective, Oxford University Press, chapter 8.

Landais, Camille (2007). Les Hauts Revenus en France 1998-2006. Une Explosion des Inégalités? Paris School of Economics Working Paper. 
Moriguchi, Chiaki and Saez, Emmanuel (2010). The Evolution of Income Concentration in Japan 18862005; in Atkinson, A. B. and Piketty, T. (editors) Top Incomes: A Global Perspective, Oxford University Press, chapter 3, pp. 76-170.

Nolan, Brian (2007). Long Term Trends in Top Income Shares in Ireland; in Atkinson, A. B. and Piketty, T. (editors) Top Incomes over the Twentieth Century. A Contrast Between Continental European and English-Speaking Countries, Oxford University Press, chapter 12.

Piketty, Thomas (2001). Les Hauts Revenus en France au 20ème siècle. Paris: Grasset, 807 pp. Other edition from Collection Hachette Pluriel (2006). pdf . annexes. data (excel).

Piketty, Thomas (2003). Income inequality in France, 1901-1998; Journal of Political Economy, 111(5): 1004-1042. Article pdf. Working paper pdf.

Piketty, Thomas (2007). Income, Wage and Wealth Inequality in France 1901-1998; in Atkinson, A. B. and Piketty, T. (editors) Top Incomes over the Twentieth Century. A Contrast Between Continental European and English-Speaking Countries, Oxford University Press, chapter 3. pdf.

Piketty, Thomas and Saez, Emmanuel (2007). Income and Wage Inequality in the United States 19132002; in Atkinson, A. B. and Piketty, T. (editors) Top Incomes over the Twentieth Century. A Contrast Between Continental European and English-Speaking Countries, Oxford University Press, chapter 5. pdf.

Riihelä, Marja; Sullström, Risto and Tuomala, Matti (2010). Trends in Top Income Shares in Finland 1966-2007. VATT Research Report 157.

Roine, Jesper and Waldenström, Daniel (2010). Top Incomes in Sweden over the Twentieth Century; in Atkinson, A. B. and Piketty, T. (editors) Top Incomes: A Global Perspective, Oxford University Press, chapter 7.

Saez, Emmanuel and Veall, Michael (2007). The Evolution of High Incomes in Canada 1920-2000; in Atkinson, A. B. and Piketty, T. (editors) Top Incomes over the Twentieth Century. A Contrast Between Continental European and English-Speaking Countries, Oxford University Press, chapter 6.

Salverda, Wiemer and Atkinson, Anthony B. (2007). Top Incomes in the Netherlands over the Twentieth Century; in Atkinson, A. B. and Piketty, T. (editors) Top Incomes over the Twentieth Century. A Contrast Between Continental European and English-Speaking Countries, Oxford University Press, chapter 10.

Switzerland Dell, Fabien; Piketty, Thomas and Saez, Emmanuel (2007). Income and Wealth Concentration in Switzerland over the Twentieth Century; in Atkinson, A. B. and Piketty, T. (editors) Top Incomes over the Twentieth Century. A Contrast Between Continental European and English-Speaking Countries, Oxford University Press, chapter 11. pdf.

Veall, Michael (2012). Top income shares in Canada: recent trends and policy implications; Canadian Journal of Economics, 45(4): 1247-1272. pdf.

Veall, Michael (2012). Top income shares in Canada: recent trends and policy implications; Canadian Journal of Economics, 45(4): 1247-1272. 
DELSA/ELSA/WD/SEM(2014)5

\section{ANNEX A1. CHARACTERISTICS AND LIMITATIONS OF INCOME DATA FROM TAX RETURNS}

This annex, which appeared as Annex A9.1 in OECD (2011a) describes in more detail some of the points that users of data from tax returns need to bear in mind in analysing and interpreting the data.

\section{Nature and characteristics of data from income tax returns}

Given that the income data are derived from tax returns, there is a risk that they could be significantly affected by under-declaration of income. Moreover, the extent of such under-reporting can vary across taxpayers. For instance, detailed audit of tax returns might suggest that the overall "tax gap" (between actual tax paid and what should have been paid if income had been correctly stated) might be of the order of $10 \%$ of personal tax income revenues, but the "gap" may be small for employees whose employer deducts tax at source and provides income information directly to the tax authorities, but over 50\% for farmers and the self-employed (where little third party information may be available for verification purposes) - see, for instance, Slemrod (2007). The extent of under-declaration of incomes may also vary across countries, reflecting for instance cultural mores with regard to tax compliance and the rigour with which the tax authorities administer the tax regime.

The tax authorities generally only collect information on income that is potentially taxable. This can result in significant exclusions (e.g. the imputed rent from owner occupation is not now taxed in most OECD countries) and breaks in time series (e.g. at the point in time when such imputed rent ceased to be taxed). Differences in tax regime can thus lead to differences in the concept of "income" used in different countries.

The tax unit varies between countries. In some countries it is the individual, while in others couples are required to file jointly. Thus the following countries operate a tax regime based on individual taxation: Australia, Canada, Italy, Japan, New Zealand (from 1953), Spain and the United Kingdom (from 1990). The following have joint filing: France, Germany, Ireland, Netherlands, Portugal and Switzerland. And some countries allow a degree of discretion to the taxpayer, including Finland, Norway and Sweden. A number of countries have changed the tax unit over time, generally in the direction of moving from joint to individual taxation.

Estimating the incomes of the "non-filing" population may be only approximate, e.g. because of differences in the income concepts used for income tax purposes and those used in estimating other incomes.

Capital gains are likely to be more important for top income groups than the rest of the population, but data on gains may not be collected with the same regularity and on the same basis as for ordinary income. Moreover, data are for realised gains and losses (rather than accruals) and realisations tend to vary with asset price cycles. Realised gains can also be quite "lumpy". An individual may have a large amount of gains one year when (s)he sells a business that has been built-up over a period of years, but then much smaller gains in subsequent years. As a result the composition of, say, the top percentile group may vary more from year to year when shares are based on income including gains rather than on income excluding 
gains. On the other hand, capital gains are often taxed more favourably than income. This may enable the rich and well advised to arrange for a substantial part of their income to take the form of asset appreciation. Ignoring gains thus may mean missing significant developments at the top of the income distribution.

Other tax planning and tax avoidance activities can also affect the amount of income declared on tax returns. For instance, it may be possible not only to defer income taxation by sheltering wealth in trusts or in a closely-held company, but also to pay a lower rate of taxation. For instance, New Zealand has found that differences between the top marginal income tax rate and the effective tax rate of income from trusts have had a significant impact on the use of trusts. Tax planning strategies for high earning employees can also include "salary sacrifice" in order to take more of their remuneration in the form of employerprovided fringe benefits that are taxed at a lower rate (if at all).

Changes in tax rates and tax reliefs can have a significant impact on the amount of income and the form of income declared to the tax authorities. This may reflect not only changes in tax planning strategies or in the amounts of evasion, but also changes in "real" behaviour such as increases in labour supply and entrepreneurial effort. These factors are discussed further in section 4 of the chapter (on explaining trends in top incomes).

\section{The concept of income}

The data collected are generally for incomes before tax. However, the precise definition of gross income varies from country to country; and may well differ substantially from economic definitions of comprehensive income such as Haig-Simons (i.e. consumption plus change in net wealth).

Broad income measures can be obtained by adding back deductible and exempt items to taxable income. For example, the United States has a concept of "cash income" that includes realised capital gains (net of capital losses) and such tax exempt items as bond interest, social security benefits and non-taxable distributions from pensions and retirement savings.

Even where capital gains are included in measures of "broad" income, the measure differs from a comprehensive measure of income as they are recorded not on an accruals but on a realisations basis; and may not be recorded at all where a country has no tax on capital gains or it is assessed separately. Other significant differences from comprehensive income are the exclusion of the imputed rent on owner occupied housing and the build-up of pension entitlements and other savings in pension funds, trusts and closely-held companies. Fringe benefits such as employer provided health insurance may also be excluded.

While the items mentioned in the previous paragraph imply that broad income falls short of comprehensive income, inflation can lead to overstatement (and other distortions) of measured income in relation to a comprehensive Haig-Simons concept, notably through the effects on nominal interest rates. In the case of savers, inflation is likely to boost their nominal interest receipts and this will be reflected in higher gross income. But this overstates their real income. (Strictly there should also be adjustments for the effects of inflation on interest paid on borrowing, but the "broad income" measure does not allow for interest paid, as a comprehensive income measure should in principle do. ${ }^{35}$

Differences between measured and a Haig-Simons measures of comprehensive income are likely to be more significant for top income recipients because they tend to have greater wealth and hence also more capital income and gains (that are more susceptible to measurement difficulties than, for instance, wage income). These differences could thus have a material effect on the share of total income going to top

35. Most countries measure income as including interest received but do not deduct interest paid. Denmark appears to be an exception. 
income recipients and its evolution over time. This is especially true in periods in which tax rates and/or the tax base change, as these changes can alter the incentives to hold wealth in one form rather than another, and result in a switch between assets whose returns are included in the "broad income" measure and assets (such as owner occupied housing) whose returns are excluded.

\section{Capital gains}

The comparison between the income measures with and without capital gains shows how important capital gains can be, particularly with regard to the evolution of income shares over time, with realised capital gains increasing particularly strongly in response to the economic cycle, notably the peaks that occurred in the years 2000 and 2007. As many countries tax capital gains at lower rates than other capital income, or not at all, tax planning through investments in assets that yield relatively large capital gains can be attractive.

The extent of the relative tax privilege given to capital gains and the scope to exploit it varies between countries and is one of the factors limiting the international comparability of data on top income shares. This cannot be overcome either by using measures that exclude gains (as gains may be more important in some countries than others) or measures that include them (as there are no data on gains for many countries).

In addition, capital gains realisations tend to be concentrated at the peaks of economic cycles. As these realisations can be very large in comparison to other income sources (as when a business in sold), this can move people temporarily into a top income group, thus overstating the real mobility into and out of top income groups. For instance in the United States, there have been surges in capital gains realisations immediately preceding expected increases in capital gains taxes, particularly as a result of the 1986 tax reforms (Saez et al., 2010). These effects produce an imperfect picture of the pattern of accrued capital gains.

\section{Tax planning}

Another form of tax planning is to adopt the business form with the most favourable tax treatment. Once again, the 1986 tax reforms in the United States provide an example: these reforms reduced the top rate of personal income tax relative to the combined burden of the corporate income tax and personal tax on dividends/ gains; and this resulted in a shift of income from the corporate tax base to the personal tax base (Saez et al., 2010). This produced an increase in reported personal incomes without any change in true underlying income, and so distorted the personal taxable income data.

\section{The tax unit}

Married couples are regarded as a single tax unit in some countries, such as France (where the tax unit also includes children) and the United States. Atkinson (2007a) points out that the effect of moving from joint taxation of couples to individual taxation depends on the joint distribution of incomes of the two partners: if all rich people are single or have partners with zero income, the share of the top X\% will increase; but if rich people all have partners with the same income, the share is reduced. In this connection, it is interesting that Atkinson (2007b) shows that the shift from joint to separate taxation in the United Kingdom led to an increase in top income shares, but this does not imply that the same will be true in other countries. 


\section{ANNEX A2. BREAKING DOWN THE ANNUAL AVERAGE INCOME GROWTH (AAIG) BY INCOME GROUP}

The methodology for calculating how much of the overall income growth is "captured" by the top $1 \%$ follows Atkinson et al. (2011).

Recall that the annual average income growth between 1976 and 2007 is given by:

$$
A A I G=\frac{1}{T} \sum_{t=1976}^{2007} g_{\bar{y}_{t}}=\frac{1}{T} \sum_{t=1976}^{2007} \frac{\bar{y}_{t}-\bar{y}_{t-1}}{\bar{y}_{t-1}}
$$

With: $\quad \bar{y}_{t}$ : average income at year $\mathrm{t}$

$g_{\bar{y}_{t}}:$ average income growth between year $\mathrm{t}$ and $\mathrm{t}-1$

$\bar{y}_{t}$ may be written as:

$$
\bar{y}_{t}=\frac{99}{100} \bar{y}_{99, t}+\frac{1}{100} \bar{y}_{1, t}
$$

with $\bar{y}_{99 t}$ and $\bar{y}_{1 t}$ being respectively the average income of bottom $99 \%$ and top $1 \%$.

Therefore AAIG can be expressed as:

$$
\begin{aligned}
& A A I G=\frac{1}{T} \sum_{t=1976}^{2007}\left[\frac{\left(\frac{99}{100} \bar{y}_{99, t}+\frac{1}{100} \bar{y}_{1, t}\right)-\left(\frac{99}{100} \bar{y}_{99, t-1}+\frac{1}{100} \bar{y}_{1, t-1}\right)}{\bar{y}_{t-1}}\right] \\
& =\frac{1}{T} \sum_{t=1976}^{2007} \frac{99}{100}\left[\frac{\left(\bar{y}_{99, t}-\bar{y}_{99, t-1}\right)}{\bar{y}_{t-1}}\right]+\frac{1}{T} \sum_{t=1976}^{2007} \frac{1}{100}\left[\frac{\left(\bar{y}_{99, t}-\bar{y}_{99, t-1}\right)}{\bar{y}_{t-1}}\right] \\
& =\frac{99}{100 T} \sum_{t=1976}^{2007} g_{\bar{y}_{99, t}} \frac{\bar{y}_{99, t-1}}{\bar{y}_{t-1}}+\frac{1}{100 T} \sum_{t=1976}^{2007} g_{\bar{y}_{1, t}} \frac{\bar{y}_{1, t-1}}{\bar{y}_{t-1}}
\end{aligned}
$$


DELSA/ELSA/WD/SEM(2014)5

Figure A2.1 Share of income growth captured by income groups, 1975-2007

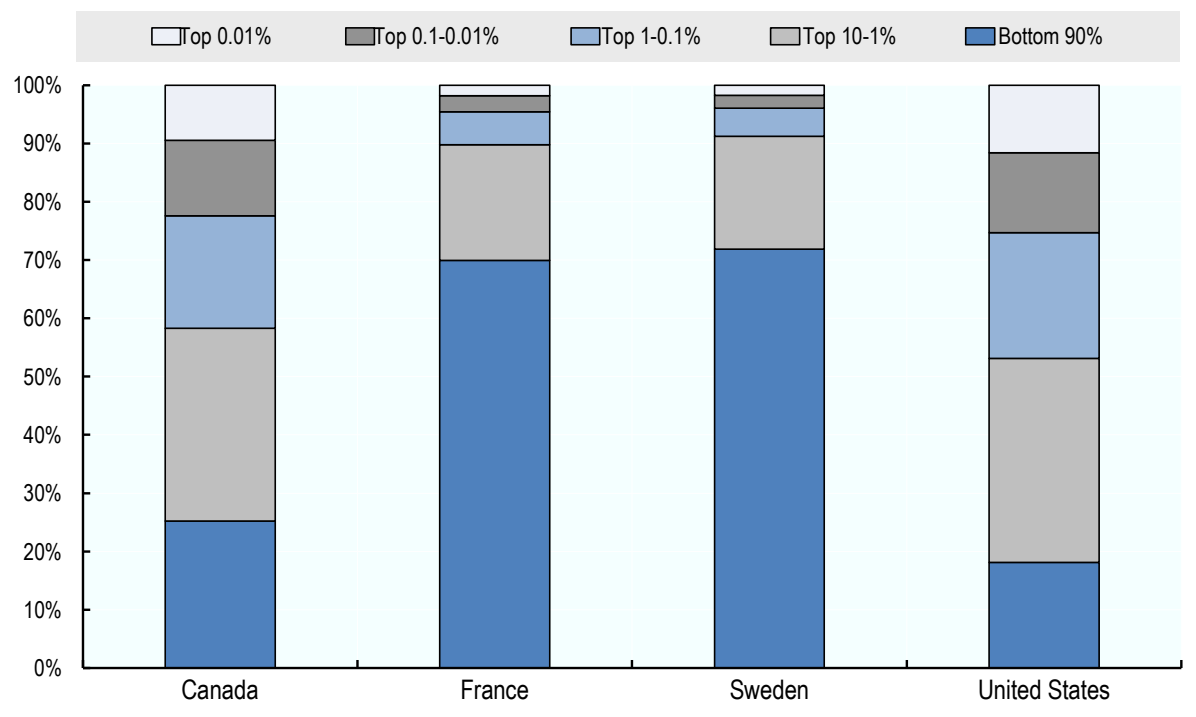

Note: Incomes refer to pre-tax incomes.

Source: World Top Incomes Database. 


\section{ANNEX A3. COUNTRY DETAILS OF THE COMPOSITION OF TOP INCOMES}

Figure A3.1 Income composition by fractile in Canada, 1970-2007

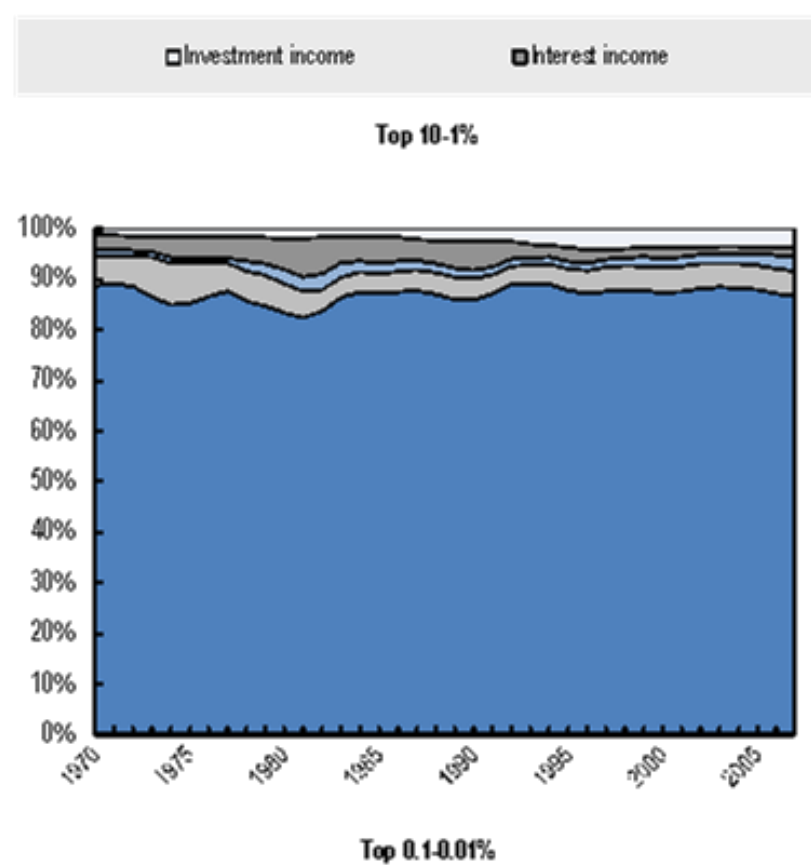

aDividends aQusiness home aSalaries

Top 1.0.1\%
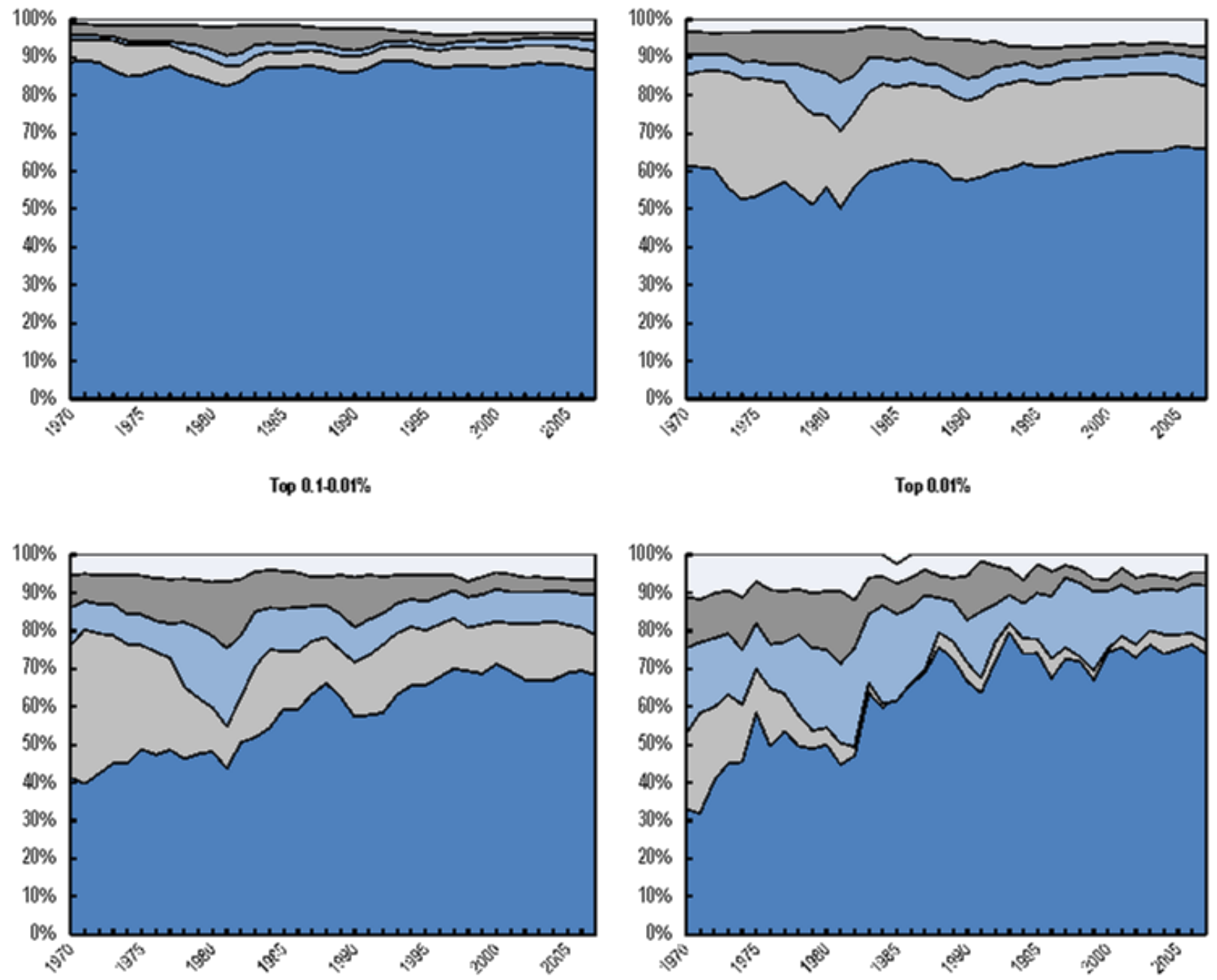

Note: Incomes refer to pre-tax incomes.

Source: World Top Incomes Database.

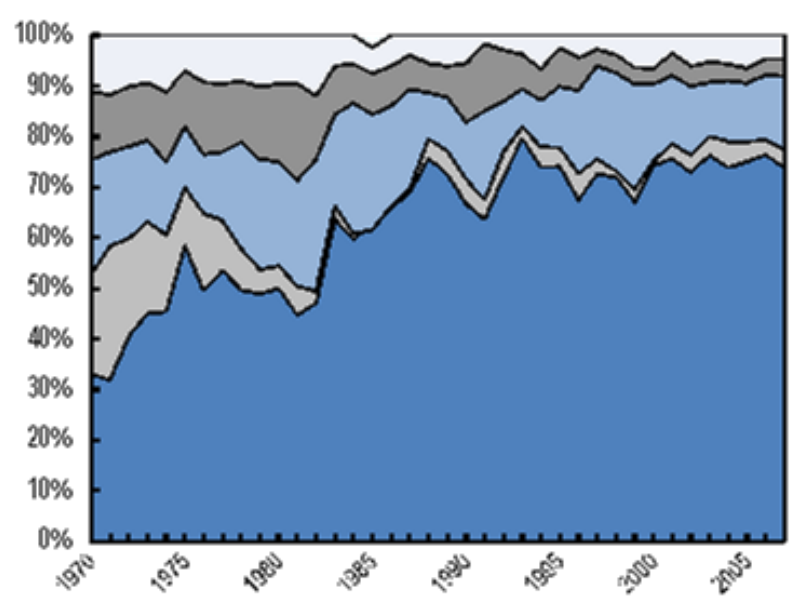


In Canada, there have been no major changes in the income composition of the top 10-1\%. As for the top $1-0.1 \%$, the business income share has decreased slightly while the share of wages and of investment income has increased. The share of capital income has been more or less stable over the period for those two groups. However, the income composition pattern within the top percentile has changed quite significantly over the recent decades. The changes are more pronounced at the very top of the distribution (top $0.01 \%$ ). The share of wages income has increased substantially between the early 1970s and the late 2000s. For the top 0.01 percent it has more than doubled over the period. At the same time the business income share has shrunk to less than for 4 percent while the share of capital income has been more than halved. Similar trends may be observed for the rest of the top $0.1 \%$. These changes in income composition reflect that, as underlined by Saez and Veal (2003), capital earners have been largely replaced by well paid executives at the very top of the income distribution.

Figure A3.2 Income composition by fractile in the United States, 1970-2010

Top $10-1 \%$

$\square$ Salaries $\square$ Business income $\square$ Dividends $\square$ Interest Income $\square$ Rents

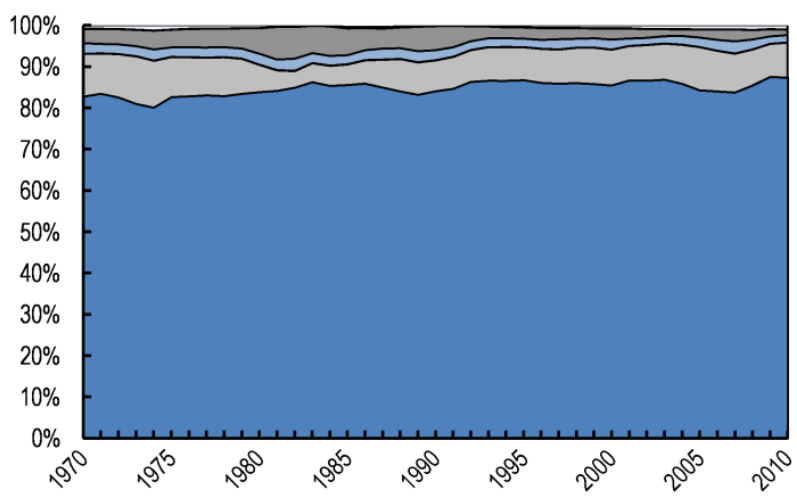

Top $0.1-0.01 \%$

Salaries $\square$ Business income $\square$ Dividends $\square$ Interest Income $\square$ Rents

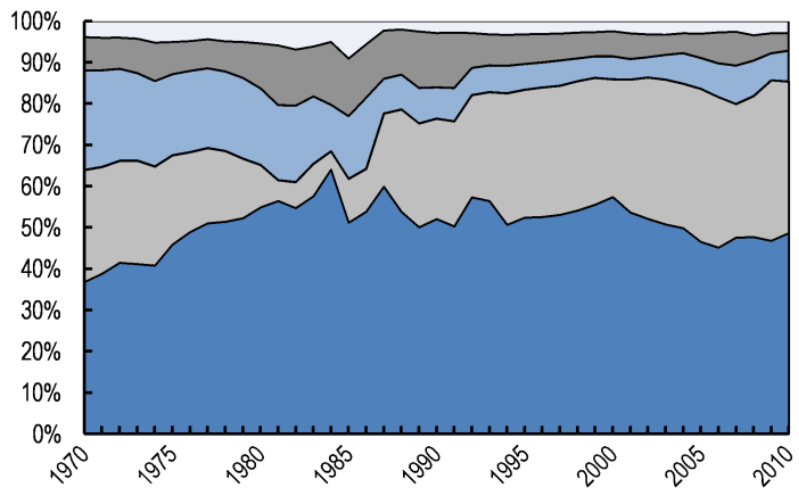

Top $1-0.1 \%$

$\square$ Salaries $\square$ Business income $\square$ Dividends $\square$ Interest Income $\square$ Rents

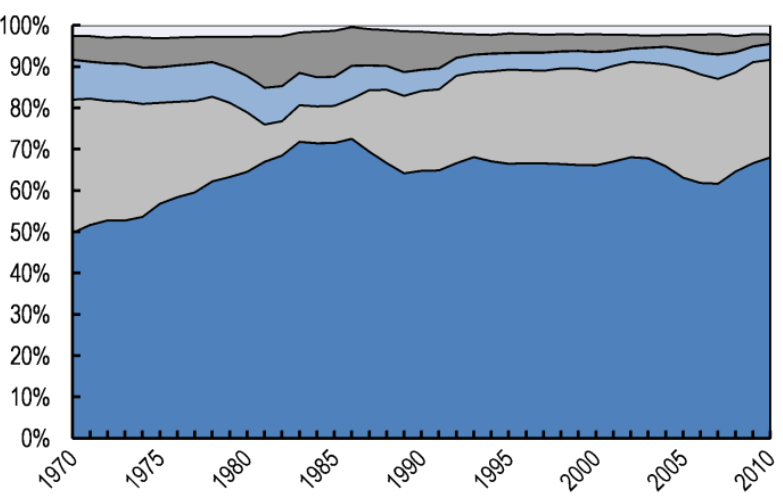

Top $0.01 \%$

Salaries $\square$ Business income $\square$ Dividends $\square$ Interest Income $\square$ Rents

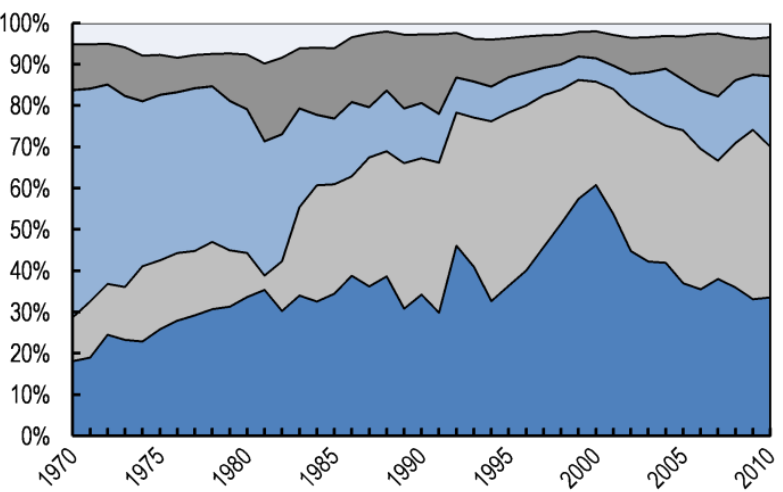

Notes: Salaries include wages, salaries and pensions. Business income encompasses income from professionals and independent workers as well as small business and farm income. Incomes refer to pre-tax incomes.

Source: World Top Incomes Database. 
While being a very long-term phenomenon (Piketty and Saez 2003) the decline of the share of capital in the top earners' income is still obvious when looking only at the recent decades. Over the last decades, the share of capital income has indeed decreased for the top decile and above in the United States. The decrease is sharper at the very top of the distribution than for the top $10-1 \%$. The capital income share has been more than halved between 1970 and 2010 for the top $0.01 \%$. For very high earners, wage and business incomes have grown larger, relative to capital income until the early 2000s. This increase is partly due to the development of stock options which are reported as wages and salaries on tax returns. The 2000s have seen a reversal of this trend, with the share of capital income increasing for the richest group, mostly at the expense of wages income. The share of wages income reaches $60 \%$ in 2000 but decreases afterwards to one third while the share of business income has remained unchanged. However, this decline is not due to decreased average wages income among the top $0.01 \%$ but is driven by the surge capital income that took place before the 2007-8 financial crisis.

Figure A3.3 Income composition by fractile in France, 1970-2006

Top $10-1 \%$

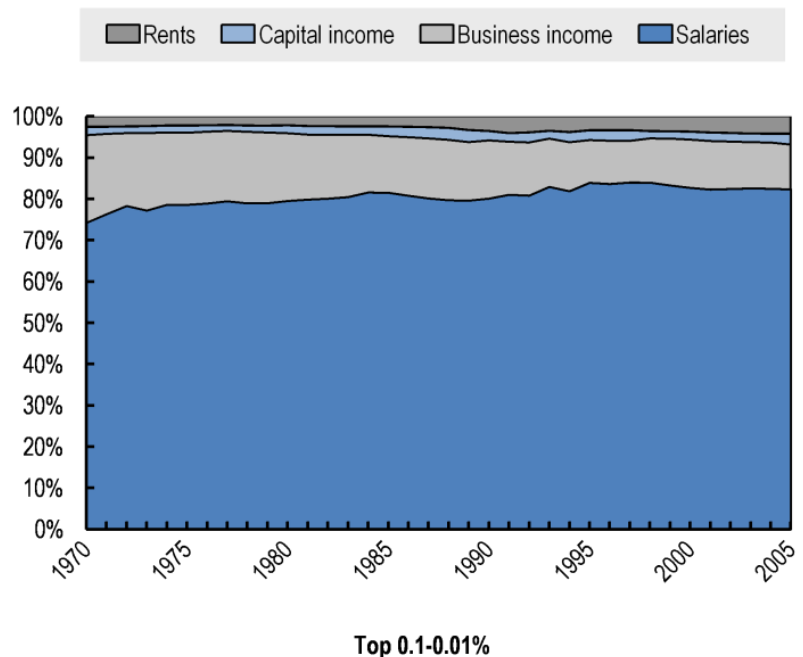

$\square$ Rents $\square$ Capital income $\square$ Business income $\square$ Salaries

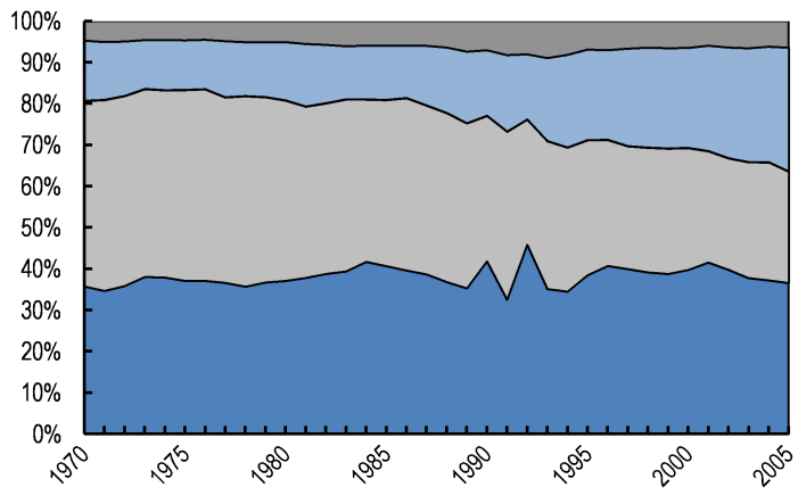

Notes: Incomes refer to pre-tax incomes.
Top $1-0.1 \%$

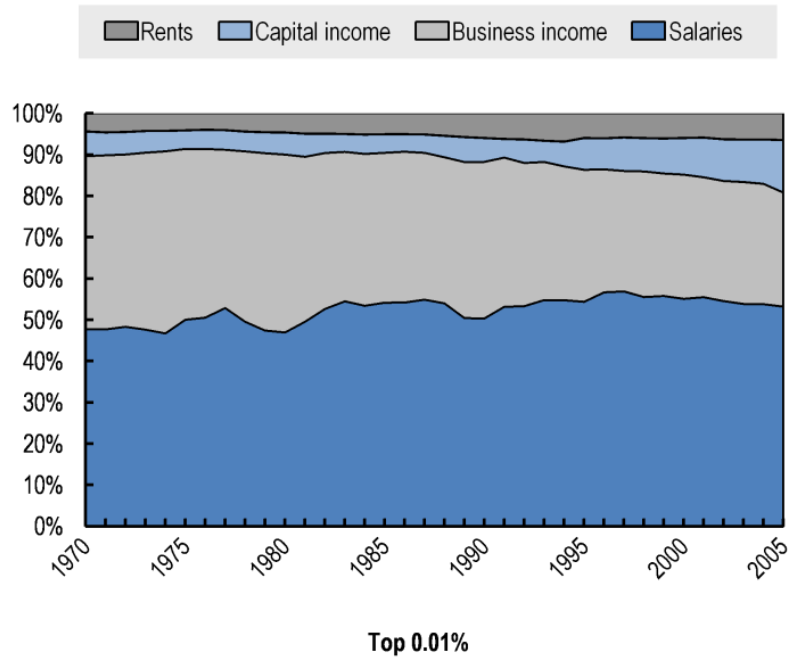

$\square$ Rents $\square$ Capital income $\square$ Business income $\square$ Salaries

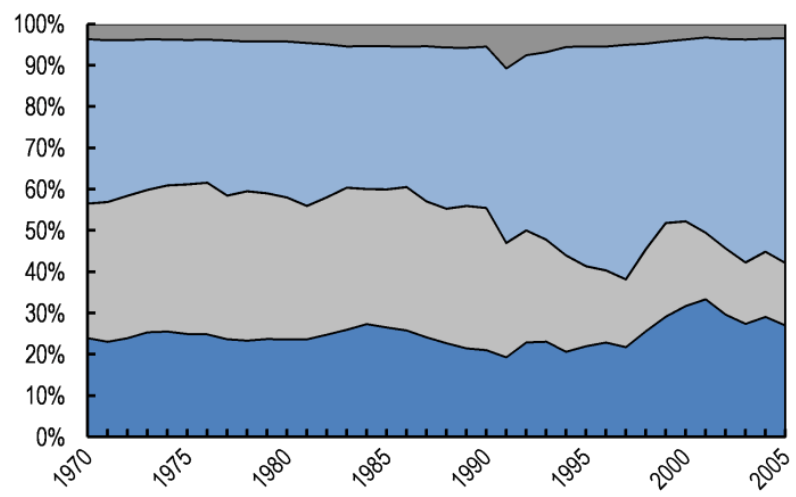

Source: World Top Incomes Database. 
Compared to Northern American countries, there has been little variation in income composition over the last four decades in France. Even though there has been a secular decrease in the capital income share for top income earners (Piketty 2001), the share of capital income has been slightly increasing over the recent decades for the top percentile. Capital income share has grown larger by $40 \%$ (about 15 percentage points) for the very richest, and has been multiplied by two for the rest of the $0.1 \%$, mostly at the expense of business income. The wages income share has indeed remained stable over the period, and has even increased mildly for the top $0.01 \%$. The increase in the share of capital income comes mostly at the expense of the share business income, which has gone down for all four income groups.

\section{Figure A3.4 Income composition by fractile in Italy, 1976-2008}

Top $10-1 \%$

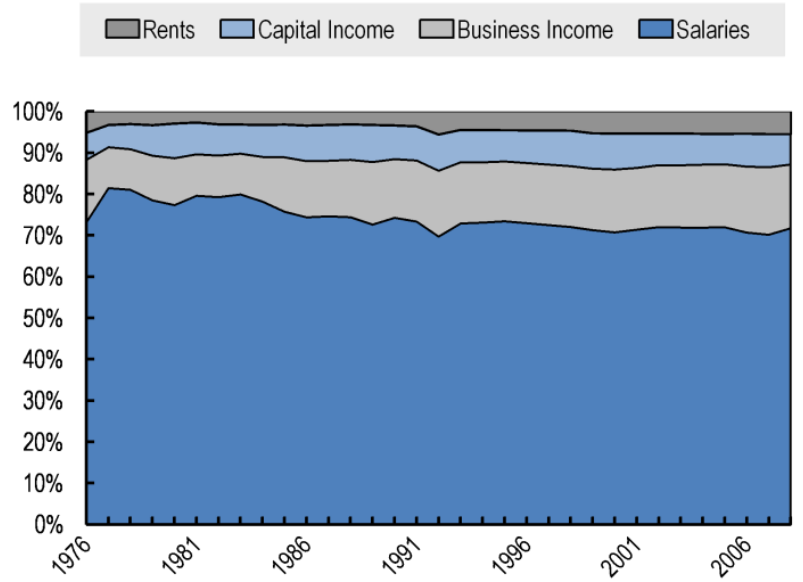

Top 0.1-0.01\%

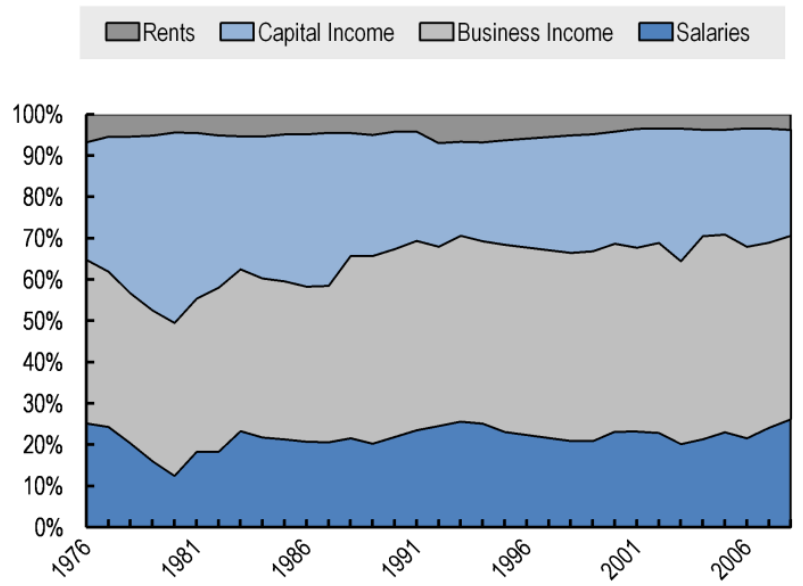

Top $1-0.1 \%$

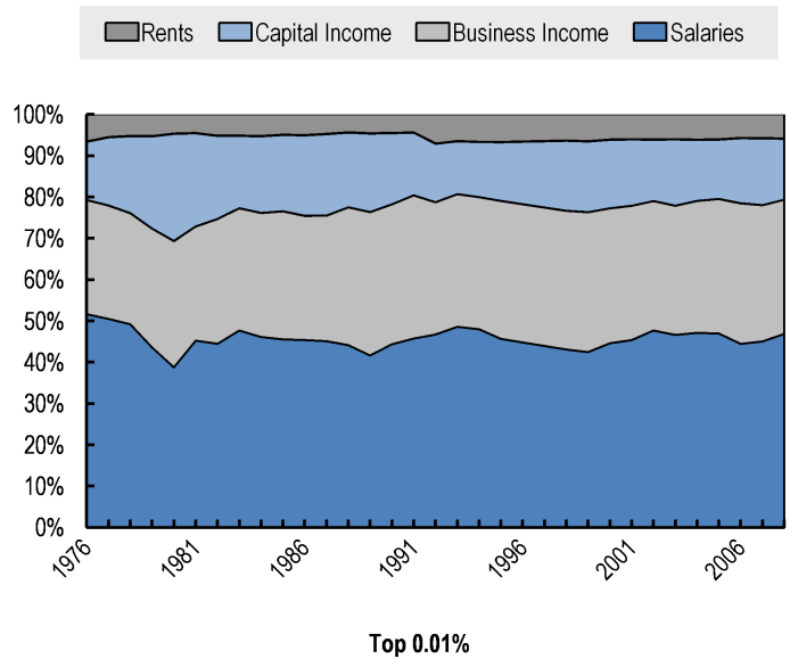

$\square$ Rents $\square$ Capital Income $\square$ Business Income $\square$ Salaries

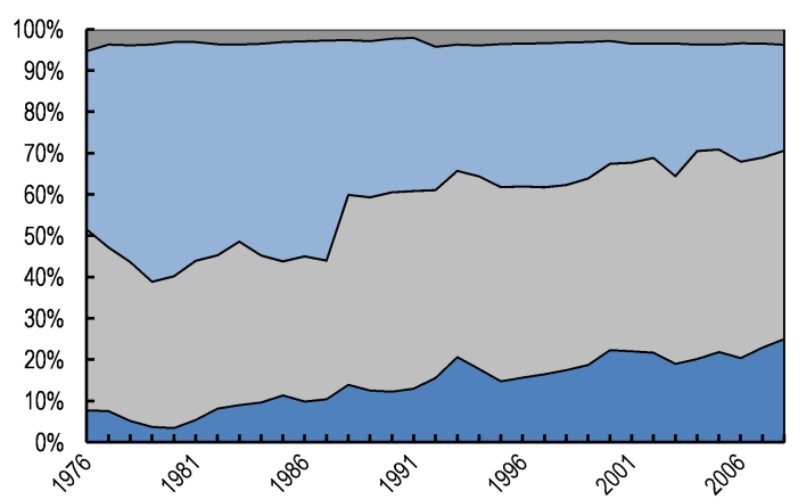

Notes: Salaries include wages, salaries and pensions. Business income encompasses income from professionals and independent workers as well as small business and farm income. Capital income includes mainly dividends and a small portion of capital gains. Linear interpolation for missing years (1996-1997). Incomes refer to pre-tax incomes.

Source: World Top Incomes Database.

In Italy, except for the top $0.01 \%$, the income composition has remained relatively stable over the recent decades, even though the share of capital income in the top $0.1-0.01 \%$ average income has decreased slightly. For the top $0.01 \%$, capital income share has shrunk by more than $40 \%$ (17.5 percentage 
points) while the share of wages income has been multiplied by more than three. There are more very well compensated top executives in the top $0.01 \%$ in the late 2000 s than in the early 1970 s, though the wages income share is low relative to other countries. Business income amounts to a substantial fraction of income for the top percentile (in 2008, 33\% for the top $1-0.1 \%, 45 \%$ for the top $0.1-0.01 \%$ and $46 \%$ for the top $0.01 \%$ ) and remains constant over the period, meaning that business-owners make up an important fraction of very high earners. This is not as important in the other countries.

Table A3.1 Occupations of taxpayers in the top 0.1 percent in the United States

\begin{tabular}{|l|c|c|}
\hline & 1979 & 2005 \\
\hline $\begin{array}{l}\text { Executives, managers, } \\
\text { supervisors (non-finance) }\end{array}$ & $48.1 \%$ & $42.5 \%$ \\
\hline $\begin{array}{l}\text { Financial professions, including } \\
\text { management }\end{array}$ & $11.0 \%$ & $18.0 \%$ \\
Medical & $7.9 \%$ & $5.9 \%$ \\
\hline Lawyers & $7.3 \%$ & $7.3 \%$ \\
\hline Computer, math, engineering & $2.3 \%$ & $2.9 \%$ \\
\hline Real estate & $1.8 \%$ & $3.7 \%$ \\
\hline Other & $21.6 \%$ & $19.7 \%$ \\
\hline
\end{tabular}

Source: Bakija, Cole and Heim (2012) 
ANNEX A4. CHANGES IN HEADLINE TAX RATES, 2007 TO 2013

Table A4.1 Changes in top PIT rate, 2007 to 2013

\begin{tabular}{|c|c|c|c|c|c|}
\hline Australia & 0.0 & 0.0 & 0.0 & 0.0 & 46.5 \\
\hline Austria & 0.0 & 0.0 & 0.0 & 0.0 & 50.0 \\
\hline Belgium & 0.0 & 0.0 & 0.0 & 0.0 & 53.7 \\
\hline Canada & 0.0 & 0.0 & 1.6 & 1.5 & 49.5 \\
\hline Chile & 0.0 & 0.0 & 0.0 & 0.0 & 40.0 \\
\hline Czech Republic & -17.0 & 0.0 & 0.0 & 7.0 & 22.0 \\
\hline Denmark & -7.5 & 0.0 & 0.0 & 0.0 & 52.2 \\
\hline Estonia & 0.0 & 0.0 & 0.0 & 0.0 & 21.0 \\
\hline Finland & -1.5 & 0.2 & 0.0 & 0.0 & 49.2 \\
\hline France & 0.0 & 5.0 & 0.0 & 3.7 & 54.5 \\
\hline Germany & 0.0 & 0.0 & 0.0 & 0.0 & 47.5 \\
\hline Greece & 9.0 & 0.0 & 0.0 & 0.0 & 49.0 \\
\hline Hungary & -4.0 & -16.0 & 0.0 & 0.0 & 16.0 \\
\hline Iceland & 10.4 & 0.1 & 0.0 & 0.0 & 46.2 \\
\hline Ireland & 6.0 & 1.0 & 0.0 & 0.0 & 48.0 \\
\hline Israel & 0.0 & 0.0 & 3.0 & 2.0 & 50.0 \\
\hline Italy & 0.3 & 3.4 & 0.0 & 0.0 & 48.6 \\
\hline Japan & 0.0 & 0.0 & 0.0 & 0.8 & 50.8 \\
\hline Korea & 0.0 & 0.0 & 4.2 & 0.0 & 42.7 \\
\hline Luxembourg & 0.0 & 2.4 & 0.0 & 1.5 & 43.8 \\
\hline Mexico & 2.0 & 0.0 & 0.0 & 0.0 & 30.0 \\
\hline Netherlands & 0.0 & 0.0 & 0.0 & 0.0 & 52.0 \\
\hline New Zealand & -3.5 & -2.5 & 0.0 & 0.0 & 33.0 \\
\hline Norway & 0.0 & 0.0 & 0.0 & 0.0 & 40.0 \\
\hline Poland & -8.0 & 0.0 & 0.0 & 0.0 & 32.0 \\
\hline Portugal & 3.9 & 4.1 & -1.0 & 5.5 & 54.5 \\
\hline Slovak Republic & 0.0 & 0.0 & 0.0 & 6.0 & 25.0 \\
\hline Slovenia & 0.0 & 0.0 & 0.0 & 9.0 & 50.0 \\
\hline Spain & 0.0 & 2.0 & 7.0 & 0.0 & 52.0 \\
\hline Sweden & 0.0 & 0.0 & 0.0 & 0.0 & 56.6 \\
\hline Switzerland & -0.4 & 0.0 & 0.0 & 0.0 & 41.7 \\
\hline Turkey & 0.1 & 0.0 & 0.0 & 0.0 & 35.7 \\
\hline United Kingdom & 10.0 & 0.0 & 0.0 & -5.0 & 45.0 \\
\hline United States & 0.5 & 0.0 & 0.0 & 4.6 & 46.5 \\
\hline Unweighted average & 0.0 & 0.0 & 0.4 & 1.1 & 43.4 \\
\hline
\end{tabular}

Sources: OECD (2013) based on OECD CTP Tax Database, plus questionnaire responses from member countries for 2013. Data for 2013 is subject to verification and perhaps also to modification as a result of changes made during legislative processes 


\section{OECD SOCIAL, EMPLOYMENT AND MIGRATION WORKING PAPERS}

Most recent releases are:

No. 159 TRENDS IN TOP INCOMES AND THEIR TAXATION IN OECD COUNTRIES, Michael Förster, Ana Llena-Nozal and Vahé Nafilyan (2014)

No. 158 Forthcoming

No. 157 CHANGES IN FAMILY POLICIES AND OUTCOMES: IS THERE CONVERGENCE?, Willem Adema, Nabil Ali, and Oliver Thévenon (Forthcoming)

No. 156 Forthcoming

No. 155 MIGRATION AS AN ADJUSTMENT MECHANISM IN THE CRISIS? A COMPARISON OF EUROPE AND THE UNITED STATES, Julia Jauer, Thomas Liebig, John P. Martin and Patrick Puhani (2014)

No. 154 SAME BUT DIFFERENT: SCHOOL-TO-WORK TRANSITIONS IN EMERGING AND ADVANCED ECONOMIES, Glenda Quintini and Sébastien Martin (2014)

No. 153 A NEW MEASURE OF SKILLS MISMATCH, Michele Pellizzari and Anne Fichen (2013)

No. 152 CATASTROPHIC JOB DESTRUCTION, Anabela Carneiro, Pedro Portugal and José Varejão (2013)

No. 151 THE PERVERSE EFFECTS OF JOB-SECURITY PROVISIONS ON JOB SECURITY IN ITALY: RESULTS FROM A REGRESSION DISCONTINUITY DESIGN, Alexander Hijzen, Leopoldo Mondauto, Stefano Scarpetta (2013)

No. 150 REDISTRIBUTION POLICY IN EUROPE AND THE UNITED STATES: IS THE GREAT RECESSION A 'GAME CHANGER' FOR WORKING-AGE FAMILIES? Herwig Immervoll, Linda Richardson (2013)

No. 149 A BIRD'S EYE VIEW OF GENDER DIFFERENCES IN EDUCATION IN OECD COUNTRIES Angelica Salvi Del Pero and Alexandra Bytchkova (2013)

No. 148 TRENDS IN POVERTY AND INEQUALITY IN DECENTRALISING INDONESIA Riyana Miranti, Yogi Vidyattama, Erick Hansnata, Rebecca Cassells and Alan Duncan (2013)

No. 147 WOMEN ENTREPRENEURS IN THE OECD: KEY EVIDENCE AND POLICY CHALLENGES Mario Piacentini (2013)

No. 146 AN EVALUATION OF INTERNATIONAL SURVEYS OF CHILDREN, Dominic Richardson and Nabil Ali (2014)

No. 145 DRIVERS OF FEMALE LABOUR FORCE PARTICIPATION IN THE OECD Olivier Thévenon (2013)

No. 144 THE ROLE OF SHORT-TIME WORKING SCHEMES DURING THE GLOBAL FINANCIAL CRISIS AND EARLY RECOVERY, Alexander Hijzen, Sébastien Martin (2012)

No. 143 TRENDS IN JOB SKILL DEMANDS IN OECD COUNTRIES, Michael J. Handel (2012)

No. 142 HELPING DISPLACED WORKERS BACK INTO JOBS AFTER A NATURAL DISASTER: RECENT EXPERIENCES IN OECD COUNTRIES, Danielle Venn (2012)

No. 141 LABOUR MARKET EFFECTS OF PARENTAL LEAVE POLICIES IN OECD COUNTRIES, Olivier Thévenon \& Anne Solaz (2012)

No. 140 FATHERS' LEAVE, FATHERS' INVOLVEMENT AND CHILD DEVELOPMENT: ARE THEY RELATED? EVIDENCE FROM FOUR OECD COUNTRIES, Maria C. Huerta, Willem Adema, Jennifer Baxter, WenJui Han, Mette Lausten, RaeHyuck Lee and Jane Waldfogel (2012)

No. 139 FLEXICURITY AND THE ECONOMIC CRISIS 2008-9 - EVIDENCE FROM DENMARK, Tor Eriksson (2012)

No. 138 EFFECTS OF REDUCING GENDER GAPS IN EDUCATION AND LABOUR FORCE PARTICIPATION ON ECONOMIC GROWTH IN THE OECD, Olivier Thévenon, Nabil Ali, Willem Adema and Angelica Salvi del Pero (2012) 
No. 137 THE RESPONSE OF GERMAN ESTABLISHMENTS TO THE 2008-2009 ECONOMIC CRISIS, Lutz Bellman, Hans-Dieter Gerner, Richard Upward (2012)

No. 136 Forthcoming THE DYNAMICS OF SOCIAL ASSISTANCE RECEIPT IN GERMANY Sebastian Königs

No. 135 MONEY OR KINDERGARTEN? DISTRIBUTIVE EFFECTS OF CASH VERSUS IN-KIND FAMILY TRANSFERS FOR YOUNG CHILDREN, Michael Förster and Gerlinde Verbist (2012)

No. 134 THE ROLE OF INSTITUTIONS AND FIRM HETEROGENEITY FOR LABOUR MARKET ADJUSTMENTS: CROSS-COUNTRY FIRM-LEVEL EVIDENCE, Peter N. Gal (VU University Amsterdam), Alexander Hijzen and Zoltan Wolf (2012)

No. 133 CAPITAL'S GRABBING HAND? A CROSS-COUNTRY/CROSS-INDUSTRY ANALYSIS OF THE DECLINE OF THE LABOUR SHARE, Andrea Bassanini and Thomas Manfredi (2012)

No. 132 INCOME DISTRIBUTION AND POVERTY IN RUSSIA, Irinia Denisova (2012)

No. 131 ELIGIBILITY CRITERIA FOR UNEMPLOYMENT BENEFITS, Danielle Venn (2012)

No. 130 THE IMPACT OF PUBLICLY PROVIDED SERVICES ON THE DISTRIBUTION OF RESOURCES: REVIEW OF NEW RESULTS AND METHODS, Gerlinde Verbist, Michael Förster and Maria Vaalavuo (2012)

No. 129 AN OVERVIEW OF AUSTRALIA'S SYSSTEM OF INCOME AND EMPLOYMENT ASSISTANCE FOR THE UNEMPLOYED, Peter Davidson, Peter Whiteford (2012)

No. 128 THE INTEGRATION OF IMMIGRANTS AND THEIR CHILDREN INTO THE LABOUR MARKET IN SWITZERLAND, Thomas Liebig, Sebastian Kohls and Karoline Krause (2012)

No. 127 THE LABOUR MARKET INTEGRATION OF IMMIGRANTS AND THEIR CHILDREN IN AUSTRIA, Karolin Krause and Thomas Liebig (2011)

No. 126 ARE RECENT IMMIGRANTS DIFFERENT? A NEW PROFILE OF IMMIGRANTS IN THE OECD BASED ON DIOC 2005/06, Sarah Widmaier and Jean-Christophe Dumont (2011)

No. 125 EARNINGS VOLATILITY AND ITS CONSEQUENCES FOR HOUSEHOLDS, Danielle Venn (2011)

No. 124 CRISIS, RECESSION AND THE WELFARE STATE, Willem Adema, Pauline Fron and Maxime Ladaique (2011)

No. 123 AGGREGATE EARNINGS AND MACROECONOMIC SHOCKS Andrea Bassanini (2011)

No. 122 REDISTRIBUTION POLICY AND INEQUALITY REDUCTION IN OECD COUNTRIES: WHAT HAS CHANGED IN TWO DECADES? Herwig Immervoll, Linda Richardson (2011)

No. 121 OVER-QUALIFIED OR UNDER-SKILLED, Glenda Quintini (2011)

No. 120 RIGHT FOR THE JOB, Glenda Quintini (2011)

No. 119 THE LABOUR MARKET EFFECTS OF UNEMPLOYMENT COMPENSATION IN BRAZIL , Alexander Hijzen (2011)

No. 118 EARLY MATERNAL EMPLOYMENT AND CHILD DEVELOPMENT IN FIVE OECD COUNTRIES, Maria del Carmen Huerta, Willem Adema, Jennifer Baxter, Miles Corak, Mette Deding, Matthew C. Gray, Wen-Jui Han, Jane Waldfogel (2011)

No. 117 WHAT DRIVES INFLOWS INTO DISABILITY?EVIDENCE FROM THREE OECD COUNTRIES Ana Llena-Nozal and Theodora Xenogiani (2011)

No. 116 COOKING, CARING AND VOLUNTEERING: UNPAID WORK AROUND THE WORLD, Veerle Miranda (2011)

No. 115 THE ROLE OF SHORT-TIME WORK SCHEMES DURING THE 2008-09 RECESSION, Alexander Hijzen and Danielle Venn (2010) 
No. 114 INTERNATIONAL MIGRANTS IN DEVELOPED, EMERGING AND DEVELOPING COUNTRIES: AN EXTENDED PROFILE,

Jean-Christophe Dumont, Gilles Spielvogel and Sarah Widmaier (2010)

No. 113 ACTIVATION POLICIES IN JAPAN,

Nicola Duell, David Grubb, Shruti Singh and Peter Tergeist (2010)

No. 112 ACTIVATION POLICIES IN SWITZERLAND,

Nicola Duell and Peter Tergeist with contributions from Ursula Bazant and Sylvie Cimper (2010)

No. 111 ECONOMIC DETERMINANTS AND CONSEQUENCES OF CHILD MALTREATMENT

Lawrence M. Berger, Jane Waldfogel (forthcoming)

No. 110 DISTRIBUTIONAL CONSEQUENCES OF LABOR DEMAND ADJUSTMENTS TO A DOWNTURN: A MODEL-BASED APPROACH WITH APPLICATION TO GERMANY 2008-09,

Herwig Immervoll, Olivier Bargain, Andreas Peichl, Sebastian Siegloch (2010)

No. 109 DECOMPOSING NOTIONAL DEFINED-CONTRIBUTION PENSIONS: EXPERIENCE OF OECD COUNTRIES' REFORMS, Edward Whitehouse (2010)

No. 108 EARNINGS OF MEN AND WOMEN WORKING IN THE PRIVATE SECTOR: ENRICHED DATA FOR PENSIONS AND TAX-BENEFIT MODELING, Anna Cristina D'Addio and Herwig Immervoll (2010)

No. 107 INSTITUTIONAL DETERMINANTS OF WORKER FLOWS: A CROSS-COUNTRY/CROSS-INDUSTRY APPROACH, Andrea Bassanini, Andrea Garnero, Pascal Marianna, Sebastien Martin (2010)

No. 106 RISING YOUTH UNEMPLOYMENT DURING THE CRISIS: HOW TO PREVENT NEGATIVE LONG-TERM CONSEQUENCES ON A GENERATION?

Stefano Scarpetta, Anne Sonnet and Thomas Manfredi (2010)

No. 105 TRENDS IN PENSION ELIGIBILITY AGES AND LIVE EXPECTANCY, 1950-2050

Rafal Chomik and Edward Whitehouse (2010)

No. 104 ISRAELI CHILD POLICY AND OUTCOMES

John Gal, Mimi Ajzenstadt, Asher Ben-Arieh, Roni Holler and Nadine Zielinsky (2010)

No. 103 REFORMING POLICIES ON FOREIGN WORKERS IN ISRAEL Adriana Kemp (2010)

No. 102 LABOUR MARKET AND SOCIO-ECONOMIC OUTCOMES OF THE ARAB-ISRAELI POPULATION Jack Habib, Judith King, Asaf Ben Shoham, Abraham Wolde-Tsadick and Karen Lasky (2010)

No. 101 TRENDS IN SOUTH AFRICAN INCOME DISTRIBUTION AND POVERTY SINCE THE FALL OF APARTHEID

Murray Leibbrandt, Ingrid Woolard, Arden Finn and Jonathan Argent (2010)

No. 100 MINIMUM-INCOME BENEFITS IN OECD COUNTRIES: POLICY DESIGN, EFFECTIVENESS AND CHALLENGES

Herwig Immervoll (2009)

A full list of Social, Employment and Migration Working Papers is available at www.oecd.org/els/workingpapers.

Other series of working papers available from the OECD include: OECD Health Working Papers. 
DELSA/ELSA/WD/SEM(2014)5

\section{RECENT RELATED OECD PUBLICATIONS:}

INVESTING IN YOUTH: BRAZIL (2014), www.oecd.org/employment/action-plan-youth.htm

AGEING AND EMPLOYMENT POLICIES: NETHLERLANDS 2014, www.oecd.org/els/employment/olderworkers

SOCIETY AT A GLANCE 2014, www.oecd.org/els/societyataglance.htm

MENTAL HEALTH AND WORK: UNITED KINGDOM (2014), www.oecd.org/els/emp/mentalhealthandworkunitedkingdom.htm

VIEILLISSEMENT ET POLITIQUES DE L'EMPLOI : FRANCE 2014: MIEUX TRAVAILLER AVEC L'ÂGE, www.oecd.org/fr/emploi/emp/vieillissementetpolitiquesdelemploi.htm

MENTAL HEALTH AND WORK: SWITZERLAND (2014), www.oecd.org/els/emp/mentalhealthandwork-switzerland.htm PENSIONS AT A GLANCE 2013, www.oecd.org/els/public-pensions/pensionsataglance.htm

HEALTH AT A GLANCE 2013: OECD INDICATORS, www.oecd.org/health/health-systems/health-at-a-glance.htm OECD EMPLOYMENT OUTLOOK 2013, www.oecd.org/els/emp/oecdemploymentoutlook.htm

CLOSING THE GENDER GAP: ACT NOW, www.oecd.org/gender/closingthegap.htm

OECD PENSIONS OUTLOOK 2012, www.oecd.org/finance/privatepensions/

INTERNATIONAL MIGRATION OUTLOOK 2012,www.oecd.org/els/internationalmigrationpoliciesanddata/

OECD EMPLOYMENT OUTLOOK 2012, www.oecd.org/employment/employmentpoliciesanddata

SICK ON THE JOB: Myths and Realities about Mental Health and Work (2011), www.oecd.org/els/disability

DIVIDED WE STAND: Why Inequality Keeps Rising (2011), www.oecd.org/els/social/inequality

EQUAL OPPORTUNITIES? The Labour Market Integration of the Children of Immigrants (2010), via OECD Bookshop

OECD REVIEWS OF LABOUR MARKET AND SOCIAL POLICIES: ESTONIA (2010), www.oecd.org/els/estonia2010

JOBS FOR YOUTH: GREECE (2010), www.oecd.org/employment/youth

JOBS FOR YOUTH: DENMARK (2010), www.oecd.org/employment/youth

OECD REVIEWS OF LABOUR MARKET AND SOCIAL POLICIES: ISRAEL (2010), www.oecd.org/els/israel2010

JOBS FOR YOUTH: UNITED STATES (2009), www.oecd.org/employment/youth

JOBS FOR YOUTH: POLAND (2009), www.oecd.org/employment/youth

OECD EMPLOYMENT OUTLOOK: Tackling the Jobs Crisis (2009), www.oecd.org/els/employmentpoliciesanddata/ DOING BETTER FOR CHILDREN (2009), www.oecd.org/els/social/childwellbeing

SOCIETY AT A GLANCE - ASIA/PACIFIC EDITION (2009), www.oecd.org/els/social/indicators/asia OECD REVIEWS OF LABOUR MARKET AND SOCIAL POLICIES: SLOVENIA (2009), www.oecd.org/els/slovenia2009 INTERNATIONAL MIGRATION OUTLOOK: SOPEMI (2010) www.oecd.org/els/migration/imo 


\section{DELSA/ELSA/WD/SEM(2014)5}

PENSIONS AT A GLANCE 2009: Retirement-Income Systems in OECD Countries (2009), www.oecd.org/els/social/pensions/PAG

JOBS FOR YOUTH: FRANCE (2009), www.oecd.org/employment/youth SOCIETY AT A GLANCE 2009 - OECD Social Indicators (2009), www.oecd.org/els/social/indicators/SAG JOBS FOR YOUTH: AUSTRALIA (2009), www.oecd.org/employment/youth OECD REVIEWS OF LABOUR MARKET AND SOCIAL POLICIES: CHILE (2009), www.oecd.org/els/chile2009 PENSIONS AT A GLANCE - SPECIAL EDITION: ASIA/PACIFIC (2009),_www.oecd.org/els/social/pensions/PAG SICKNESS, DISABILITY AND WORK: BREAKING THE BARRIERS (VOL. 3) - DENMARK, FINLAND, IRELAND AND THE NETHERLANDS (2008), www.oecd.org/els/disability

GROWING UNEQUAL? Income Distribution and Poverty in OECD Countries (2008), www.oecd.org/els/social/inequality JOBS FOR YOUTH: JAPAN (2008), www.oecd.org/employment/youth JOBS FOR YOUTH: NORWAY (2008), www.oecd.org/employment/youth JOBS FOR YOUTH: UNITED KINGDOM (2008), www.oecd.org/employment/youth JOBS FOR YOUTH: CANADA (2008), www.oecd.org/employment/youth JOBS FOR YOUTH: NEW ZEALAND (2008), www.oecd.org/employment/youth JOBS FOR YOUTH: NETHERLANDS (2008), www.oecd.org/employment/youth For a full list, consult the OECD online Bookshop at www.oecd.org/bookshop 